NBSIR 75-933

\title{
A Study of the National Humidity and Moisture Measurement System
}

Arrold Wexler

Institute for Basic Standards

National Bureau of Standards

Washington, D. C. 20234

August 1975

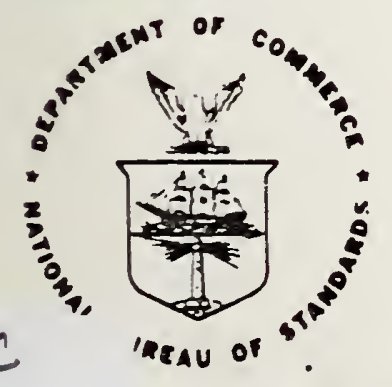

100

456

IEPARTMENT OF COMMERCE

no. 75- 933 NAL QUREAU OF STANDAROS

1975

C. 2 
NBSIR 75-933

\section{A STUDY OF THE NATIONAL HUMIDITY AND MOISTURE MEASUREMENT SYSTEM}

Arnold Wexler

Institute for Basic Standards National Bureau of Standards

Washington, D. C. 20234

August 1975

U.S. DEPARTMENT OF COMMERCE, Rogers C.B. Morton, Secretary James A. Baker, III, Under Secretary

Dr. Betsy Ancker-Johnson, Assistant Secretary for Science and Technology 

EXECUTIVE SUIMARY

1. INTRODUCTION

2. STRUCTURE OF THE MEASUREMEMT SYSTEM

2.2 Basic Technical Infrastructure ${ }_{2} \ldots \ldots . \ldots . \ldots$

2.2.1 Documentary Specification system . . . . . . . . . . 5

2.2 .2 Instrumentation system . . . . . . . . . . 7

2.2 .3 Reference Data ................. 9

2.2 .4 Reference Materiais. . . . . . . . . . . 11

2.2 .5 Science and People $\ldots$. . . . . . . . 12

2.3 Realized lleasurement Capabilities ..................... 12

2.4 Dissemination and Enforcement Network $\ldots$

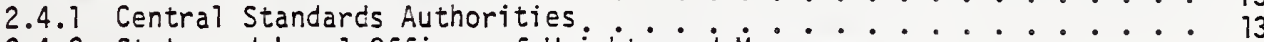

2.4.2 State and Local Offices of Weights and Measures. . . . . . .

2.4 .3 Standards and Testing Laboratories and Services. . . . . . . 13

2.4 .4 Regulatory Agencies .................. 15

2.5 Measurements Transaction Matrix $\therefore: \ldots 15$

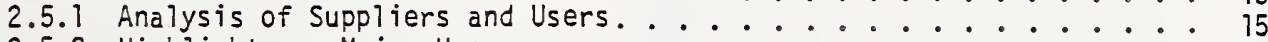

2.5 .2 Highlights re Major Users

3. IMPACT, STATUS AND TRENDS OF MEASUREMENT SYSTEM. ............. 15

3.1 Impact of lleasurements. . . . . . . 15

3.1.1 Functional, Technological and Scientific Apprications. . . . 15

3.1 .2 Economic Impacts--Costs and Benefits . . . . . . . . . 17

3.1 .3 Social, Human, Person-in-the-Street Impacts. . . . . . . 23

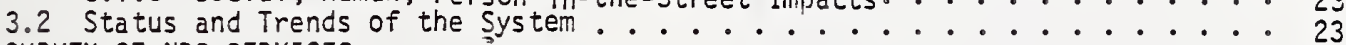

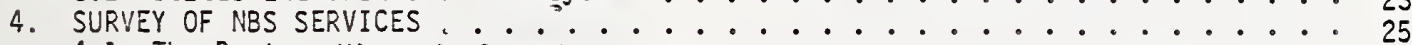

4.1 The Past - Historical Background . . . . . . . . . 25

4.2 The Present--Scope of NBS Services.............. 27

4.2.1 Description of NBS Services. . . . . . . . . 27

4.2 .2 Users of NBS Services. . . . . . . . . . . . . . 37

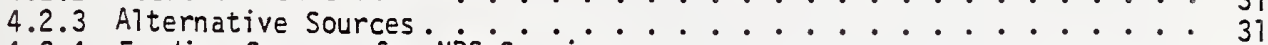

4.2.4 Funding Sources for NBS Services . . . . . . . . . 31

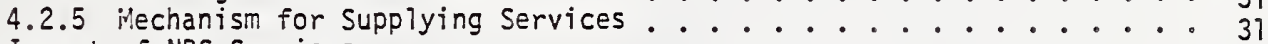

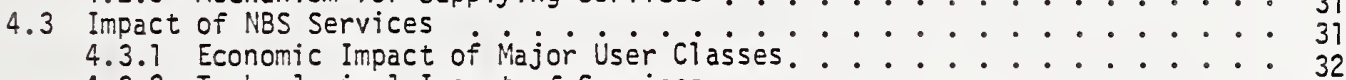

4.3 .2 Technological Impact of Services . . . . . . . . 32

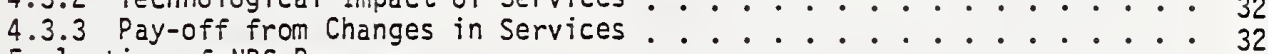

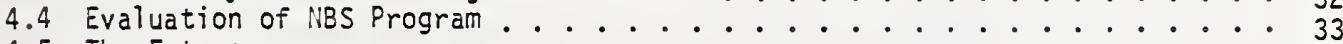

4.5 The Future

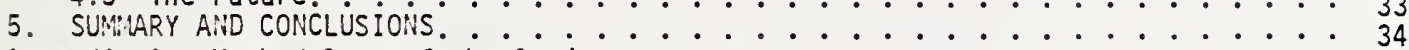

Appendix A. Methodology of the Study. . . . . . . . . . . . . 34

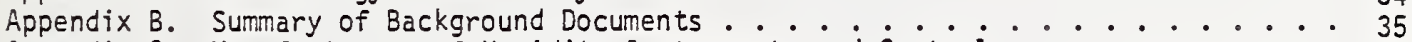

Appendix $C$. Manufacturers of Humidity Instruments and Controls. . . . . . . . 37

Appendix D. Manufacturers of Moisture Instruments and Controls. . . . . . . 39

Appendix E. Selected Compilations of Standard Reference Data for

Humidity and Moisture ........................ 40

Appendix F. NBS Interfaces wi th Users of Humidity Measurement

System over the Past Decade ................. 41

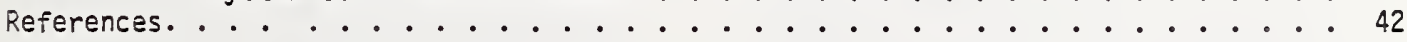




\section{LIST OF FIGURES}

Figure 1. Interrelationship of humidity units

Figure 2. Hierarchy of humidity standards

Figure 3. Accuracy chart

Figure 4. NBS humidity measurement services

Figure 5 . NBS humidity measurement capabilities

\section{LIST OF TABLES}

Tabie 1. Materials covered by ASTM standards with procedures for the measurement of moisture

Table 2. Materials covered by ASTM standards for measurement of water vapor transmission

Table 3. Materials covered by ASTM standards requiring conditioning or control of cabinets or rooms

Table 4. Organizations having standards, specifications, or procedures involving humidity or moisture measurement and control

Tabie 5. Absolute methods of humidity measurement

Table 6. Humidity generators

Tabie 7. Secondary humidity standards

Table 8. Fixed humidity points

Table 9. Classification of humidity measurements

Table 10. Classification of moisture measurements

Table 11. Absolute methods of moisture measurement

Table 12. Direct measurements transactions matrix

Table 13. Impact of humidity measurement and control on selected disciplines, industries, and technologies

Table 14. Industrial statistics on selected manufactured products for 1973

Table 15. Relative order of occurrence of various types of measurements in the process industries

Table 16. Relative humidity and temperature requirements for some industriai processes and products control

Table 17. Agricultural statistics on selected grain and oilseed crops

Table 18. MBS calibration ranges and accuracies

Table 19. Instruments calibrated by NBS over the last ten years

Table 20. Users of instruments calibrated by NBS over the last ten years 


\title{
A STUDY OF
}

THE NATIONAL HUMIOITY AND MOISTURE MEASUREMENT SYSTEM

\author{
Arnold Wexler \\ Heat Division \\ Institute for Basic Standards
}

August 1975

\section{EXECUTIVE SUMMARY}

Water in the form of vapor and liquid (moisture) is an ubiquitous substance that pervades our earth affecting almost every material, process, device, instrument and product. Life itself depends on its presence. It plays an important role in the scientific disciplines, in many branches of engineering, in medicina, meteorology, and agriculture, and in such diverse industrial fields as airconditioning, drying, refrigaration, storage, food processing, electronics and comunications. Because of the innate interaction between water and its surroundings, and the pervasive effect water has, it is essential to be able to determine or adjust the amount present, that is, to be able to measure and cantrol its quantity in a given environment or material.

Instruments which measure water content in the vapor phase are classified as hygrometers; those that measure water content in the liquid phase, that is, that measure moisture in liquids and solids, are classified as moisture meters. This study delineates the infrastructure of the humidity and moisture measurement system and the interrelationships that exist between the fundamental units, the standarcs, the calibration procedures, the instruments, and the users. It examines the impact that this measurement system has on economic, scientific, social and industrial ascects of our national life. Finally, it identifies and analyzes certain deficiencies and needs in the National Measurement System.

The primary responsibility of NBS is to provide the central basis for the liational Measurement System, to coordinate that system nationally and with those of other rations, and to furnish the essential services leading to accurate and uniform measurements throughout the USA. The study shows that the liBS base for the humidity measurement system comprises five primary elenent: (1) measurements research, (2) standards development, (3) development of special instruments for specific end uses: (4) prototype development and construction of new instruments to meet the needs for secondary standards, and (5) issuance of publications, such as monographs, to provide users with infomation on instruments, methods of measurement, sources of accuracy, iBS capabilities, etc. Cocrdination is achieved through the dissemination of information, data, techniques, methods, procedures, reierences and reprints to Government, industry, colleges, universities, institutes, industrial laboratories, foreign

govermments and foreign organizations. One important link in the ccordination chain is the presentation of tutorial lectures before professional societies, workshops, seninars, clinics and training courses. Direct services are ofiered through (1) calibration of plant and laboratory standards, (2) tests for compliance with covernment procurement specifications, (3) evaluation and testing of sensors for special government programs and (4) tests for the public when comercial, industrial or university laboratories cannot meet required needs.

This study categorizes and classifies the instrumentation in current use in tems of principles of operation, comercial sources, and end uses. At least twentyfour distinct types of humidity instruments and conirols and seventeen distinct types of moisture meters and controis are known to be made in the USA. These are availabie from-more than 100 manuiacturers.

Information gathered so far indicates that the annual busiress volume of the identifiable instrumentation industry for humidity and moisture measurement and control is of the order of 35 to 70 million dollars. This instrumentation impacts on a great diversity of disciplines, industries and technologies, creating a second order sifect that is estimated to run into the billions. 
In the process industries such parameters as temperature, flow, liquid level, pressure, chemical composition, density, viscosity, humidity and moisture are monitored and regulated. It is estimated that of the total number of such measurements, humidity constitutes 3.5 percent and mo isture 0.7 percent. The economic loss resulting from measurement inaccuracies is substantial. For example, the uncertainties in the determination of moisture in grain, such as corn, can result in annual dollar losses from excess moisture or excess drying of $\$ 135$ to 375 million.

The amount of water in a material is of vital commercial concern--in buying, selling, shipping, etc. It greatly affects the properties of materials. The relative humidity of the environment and the moisture content of a given material must be controlled for many industrial processes and for the production of a great many products. Only through such control can such factors as product uniformity, quality, and process economy be achieved. Such control contributes to the conservation of fuel and energy in drying processes. In the testing of many materials for strength, performance, iife, etc., humidity control plays a paramount role. For example, a review of American Society for Testing and Materials (ASTM) standards has identified at least 45 categories of materials that must be conditioned in cabinets or rooms prior to test and 84 categories of matorials covered by procedures for the measurement of moisture content. other organizations having standards, specifications or procedures involving humidity or moisture measurement and control include Air Conditioning and Refrigeration Institute (ARI), American National Standards Institute (AHSI), American Petroleum
Institute (API), American Society for Agricultural Engineers (ASAE), American Society of Heating, Refrigerating and Air Conditioning Engineers, Inc. (ASHRAE), American Society of Mechanical Engineers (ASME), Association of Official Analytical Chemists (AOAC), Cooling Tower Institute (CTI), U. S. Department of Agriculture (USDA), U. S. Department of Defense (DOD), Technical Associations of the Pulp and Paper Industry (TAPPI), Underwriters Latoratories (UL), International Organization for Standardization (ISO), International Electrotechnical Comission (IEC), U. S. Department of Commerce-National Oceanographic and Atmospheric Administration (NOAA), and the World Meteorological Organization (WMO).

This study has disclosed several shortcomings and deficiencies in the National Measurement System. As an example, there are no nationai standards for moisture measurements. Various technologies have established recomended practices or specifications through voluntary documentary organizations such as The American Society for Testing and Materials. In the agricultural field, the U. S. Department of Agriculture and the Association of Official Analytical Chemists have established reference methods for determining moisture in specific materials, yet none is directly traceable to NBS.

As a result of this study, and in response to requests from state weight and measures officiais, NBS has initiated a program with the broad goal of providing the central basis within the USA of a consistent measurement system for moisture in materials and to provide essential moisture measurement services throughout the Nation. 


\section{INTRODUCTION}

Water vapor and moisture are ubiquitous, pervading our earth and affecting almost every material, process, device, instrument and product. Life itself depends on their presence. They play important roles, in the scientific disciplines, in many branches of engineering, in medicine, meteorology and agriculture, and in such diverse industrial fields as airconditioning, drying, refrigeration, storage, food processing, electronics and comminications. Because of the innate interaction between water vapor and moisture and their surroundings, and the effects this has, it is essential to be able to determine or adjust the amount present, that is to measure or control the quantity in a given environment or material.

The amount of water vapor or moisture associated with other substances, in common with such other measurable quantities as mass, length, time, force and pressure, is a parameter of the National Measurement System $[1-3]$. This system is a complex structure of interrelated scientific, technological, social and economic components which has as its essential function the provision of a measurement bas is for interchangeability and decisions for action in public affairs, comerce, industry, science and engineering. This study assesses the status of the system, that is it determines the current base line of that segment that is concerned with the measurement of water vapor and moisture. It focuses on the physical process of measuring and controlling water vapor and moisture. It describes the nature, extent and economic dimensions of the systen. It indicates impacts and trends, identifies deficiencies and shortcomings, and shows what role NBS plays in the system.

\section{STRUCTURE OF THE MEASUREMENT SYSTEM}

\subsection{Conceptual System}

Humidity in the broadest sense is a term designating the water vapor content of a gas or the moisture content of a liquid or solid material. In a narrower context, the term humidity is limited to denote the water vapor content of a gas, whereas the term moisture content designates the water associated with a liquid or solid material.
In humidity and moisture measurement, the basic problem is the identification and quantification of the water (as vapor or 1 iquid) associated with a second gaseous, i iquid or solid substance. It is usually sufficient to assume that the substance and $i t s$ associated water constitute a two-component mixture even though the substance itseli may be a multi-component mixture as, for example, atmospheric air. The primary quantity for designating the amount of one constituent in a mixture is its mass. Let the mass of water be $\mathrm{m} w$ and the mass of the second (dry) constituent be md, then the amount of water in the binary mixture will be given by either of two ratios

or

$$
q=\frac{m_{w}}{m_{w}+m_{d}}
$$

$$
r=\frac{m}{m_{d}} .
$$

If the mixture is gaseous, then the ratio $q$ is called the specific humidity and the ratio $r$ is called the mixing ratio or humidity ratio. If the second constituent is a liquid or solid then $q \times 100$ is the percentage moisture content on a "wet" basis and $r \times 100$ is the percentage moisture content or a "dry" basis. For gaseous mixtures the amount of water vapor oresent, that is, the humidity can also be given in terms of volume, pressure, mole and density ratios either on a "wet" or "dry" basis. The derivation of these expressions of humidity from the base units of measurement (mole, mass, length, time) is shown in figure 1. The humidity exoressions are linked to the base units through definitions and equations of physics. By applying the gas law's any one expression of humidity can be converted into any other equally valid expression. Futhermore, because the maximum amount of water vapor that can occupy a given volume at a fixed temperature is predicted by the saturation vapor pressure, it is often convenient and useful to state the actual amount of water vapor present with respect to this maximum, leading to expressiors of relative water vapor content. 


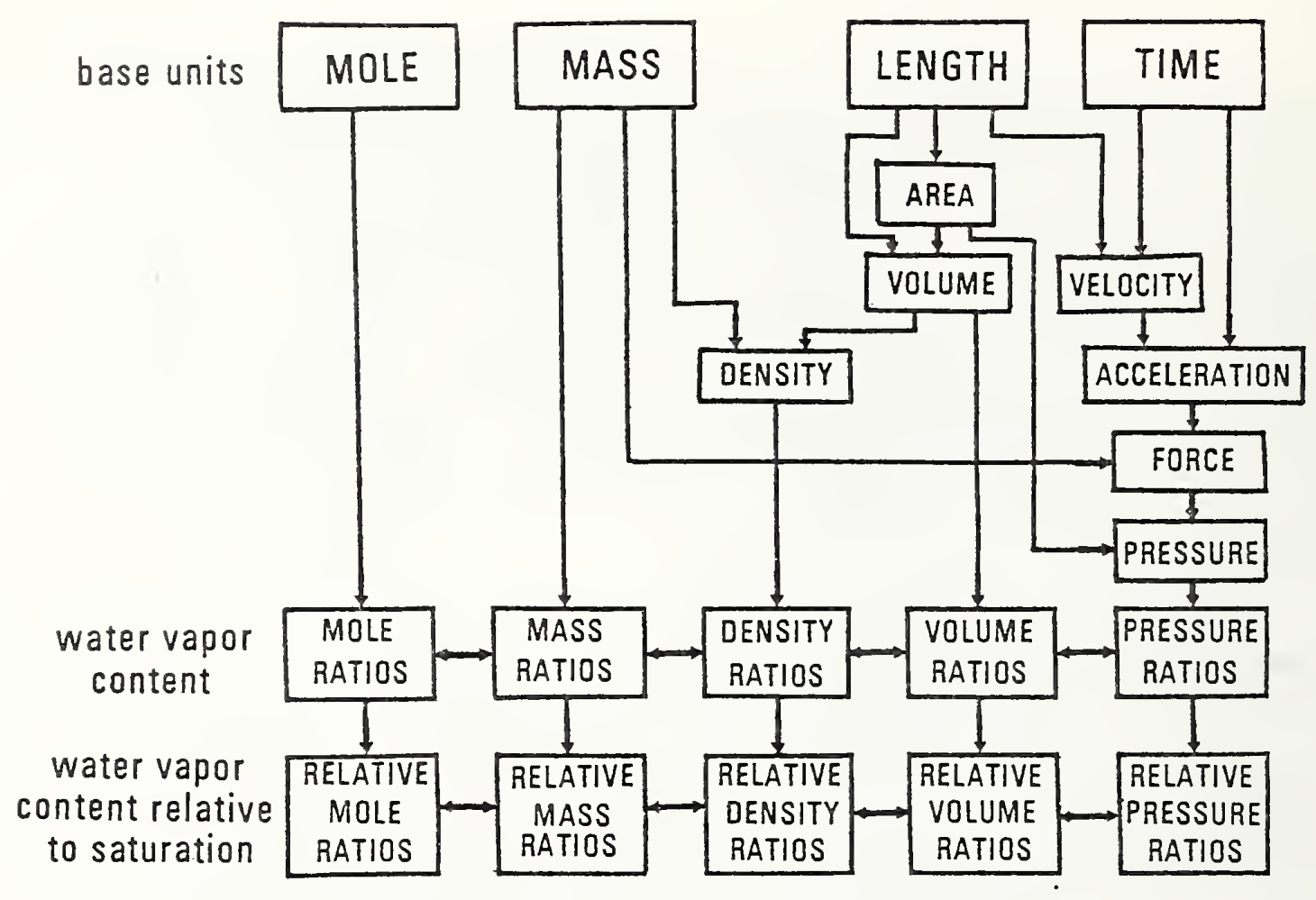

Figure 1. Interrelationship of humidity units

\subsection{Basic Technical Infrastructure}

The humidity and moisture segment of the National Measurement System has an infrastructure comprising such recognizable components as ( 1 ) a documentary specification system, (2) an instrumentation system, (3) reference data, (4) reference materials and (5) science and people. The documentary specification system is a collection of international, legal, mandatory and voluntary agreements which describe the test methods and measurement techniques for evaluating the behavior, performance and characteristics of materials, devices, instruments and products under stipulated conditions of humidity and moisture. It establishes humidity criteria for testing and conditioning, and specifies methods, procedures and instruments for measuring humidity and moisture. The instrumentation system provides calibrated, traceable humidity and moisture instrumentation that is consistent and compatible with the Nlation's measurement standards.

It is this instrumentation system which enables a user to make the measurements that are needed in monitoring or controlling a manufacturing process, or in determining the properties or performance of a material or device, or in studying the phenomena and laws of physics.

Reference data provide the measurement user with critically evaluated numerical values of the properties and the characteristics of materials. For example, the properties of the ordinary water substance are of paramount importance to humidity and moisture measurements. These and similar data simplify the measurement process, allowing a user to obtain answers, perform experiments, or design instruments, apparatus, devices and manufacturing processes without making extensive measurements himself or, at least, allowing him to eliminate part 
of a measurement chain. When a particular substance, say, water, has been adequately characterized it may be used as a reference material. Such a substance, when combined with suitable techniques for its use, can be employed to calibrate instruments.

The varicus comoonents of the intrastructure interact with each other, forming feed-back loops that stimulate the advancement and development of the Hational lieasurement System. The interfaces between these components are people applying science and technology, operating under economic and societa? constraints, sometimes acting alone, but rore frequently in an organization as, for example, in a Government agency, in a professional society, or in an industrial or trade association.

\subsubsection{Documentary Specification System.}

The documentary specification system is best illustrated by the standares of the American Society of Testing and Materials (ASTM). These standards describe procedures and instruments for the measurement of humidity and moisture; they specify humidities for conditioning materials prior to test; they describe test chambers and rooms for controlling humidity or subjecting materials to cyclic conditioning; and they specify standard atmospheres which must prevail when certain classes of materials are to be tested. Table 1 contains a list of materials that are covered by ASTM procedures for moisture measurement. Table 2 contains a list of materials covered by ASTI specifications for the measurement of water vapor transmission under stipulated conditions of humidity. Table 3 contains a list of materials that are covered by ASTM specifications requiring conditioning in cabinets or rooms under controlled humidity. Other organizations have established similar standards, specifications and procedures involving humidity or moisture measurement and control dealing with their own areas of interest. Some of these organizations are tabulated in table 4 .

Table 1. Materials covered by AST standards with orocedures for the neasurenent of moisture

\begin{tabular}{|c|c|c|}
\hline 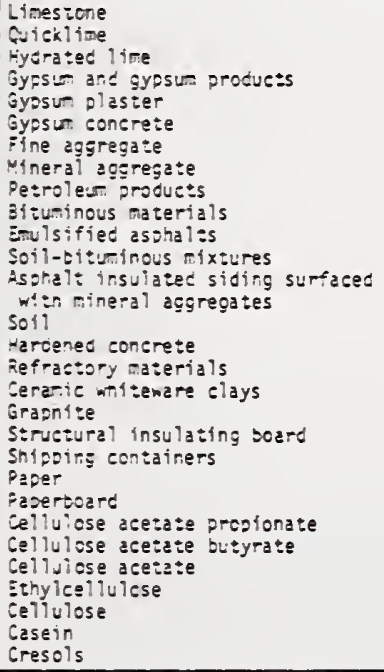 & 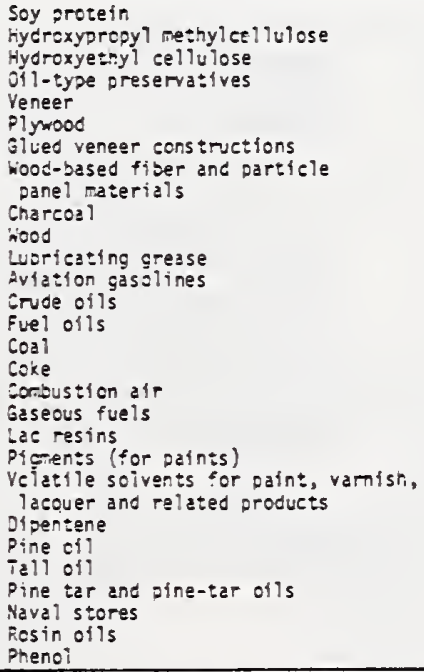 & $\begin{array}{l}\text { Xylenols } \\
\text { Naohthalene } \\
\text { Pyridene } \\
\text { Quinoline } \\
\text { Fatty nitrogen products } \\
\text { Soap } \\
\text { Soap products } \\
\text { Sulfonated and sulfated ofls } \\
\text { Industrial netal cleaning } \\
\text { conpositions } \\
\text { Antifreeze } \\
\text { Alkylbenzene suifonates } \\
\text { Chlorine-containing bleaches } \\
\text { Activated carton } \\
\text { E:hylene glycols } \\
\text { Propylene glycols } \\
\text { Monobasic organic acids } \\
\text { Licuid chlorine } \\
\text { iextile materials } \\
\text { hool } \\
\text { kool protucts } \\
\text { Cotton } \\
\text { Cotton products } \\
\text { Nylcn injection molding and extrusicn } \\
\text { meterials } \\
\text { TfE-fluorocarbon resin molding and } \\
\text { extrusion materials } \\
\text { Urethane fosm polyol raw materials } \\
\text { Electrical insulating oils } \\
\text { Electrical insulating oases }\end{array}$ \\
\hline
\end{tabular}

Table 2. Materials coverec by AST s:andards for neasurerent of water vafor transmission

\begin{tabular}{|c|c|c|}
\hline $\begin{array}{l}\text { Fiterocard } \\
\text { dypsum products } \\
\text { hocd oroducts } \\
\text { plaster products } \\
\text { plasties }\end{array}$ & $\begin{array}{l}\text { Paper } \\
\text { Plastic films } \\
\text { Sheet meterials } \\
\text { ispnali-treated papers }\end{array}$ & $\begin{array}{l}\text { Asphalt-treated felis } \\
\text { Flexitle sneets } \\
\text { Packages } \\
\text { Organic coating films }\end{array}$ \\
\hline
\end{tabular}




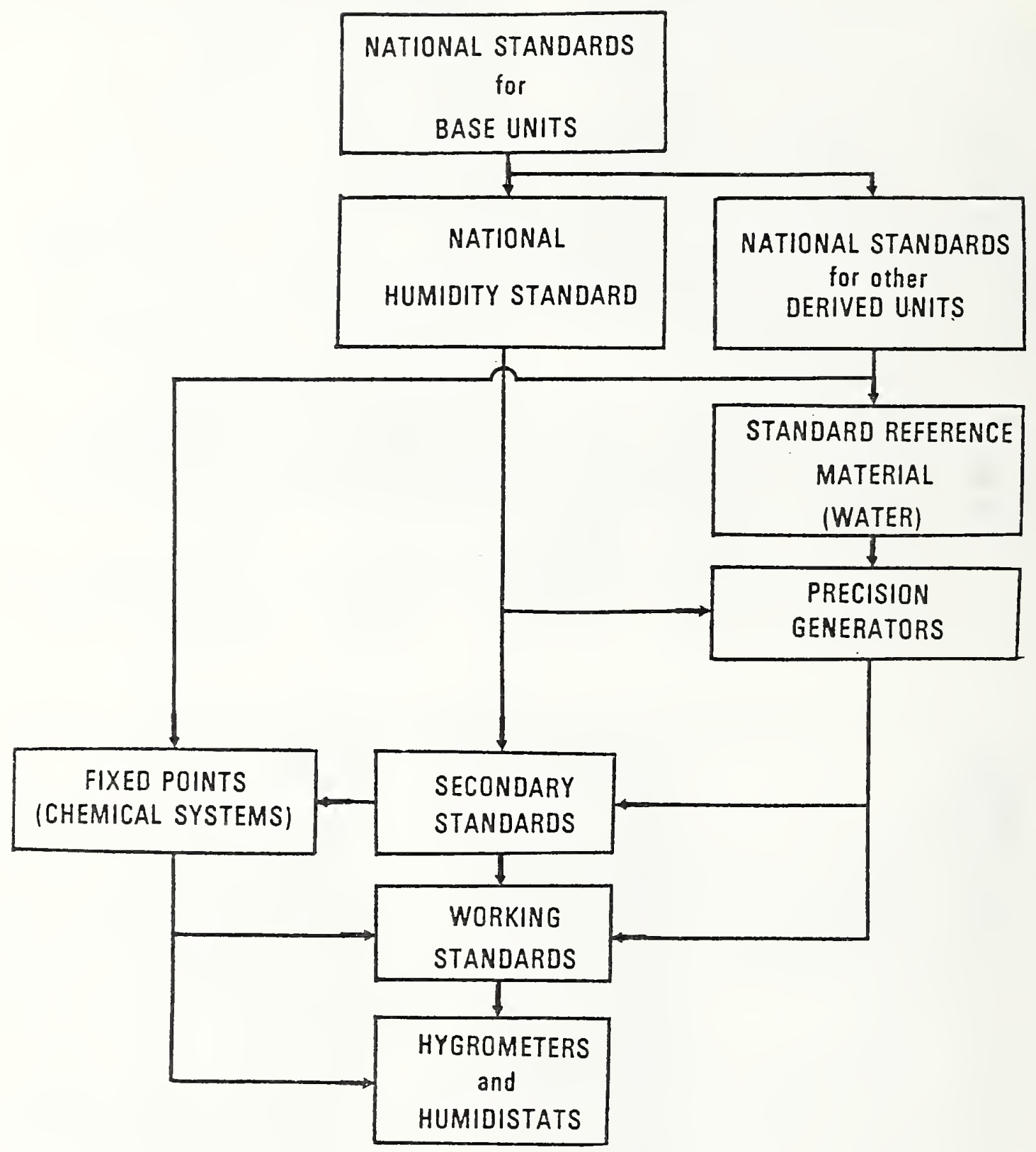

Figure 2. Hierarchy of humidity standards 


\subsubsection{Instrumentation System.}

The hierarchy of humidity standards is shown in figure 2. There are two routes by which the units of humidity are propagated to the ultimate user. Both originate with the national standards for the base units. One route leads directly to the primary standards for humidity and then through precision generators, secondary standards and fixed points to working standards and, finally, to working instruments and controls in industry, science and commerce. The second route leads to the national standards for derived units, such as pressure, which, in turn, are used to characterize the pure water substance. The latter then is used as the standard reference material in precision generators to produce known (predictable) levels of humidity in selected test gases. Secondary standards or working standards can now be calibrated with these gases.

There are several absolute methods, outlined in table 5 , which are suitable for use over parts of the humidity domain as primary standards. Generators capable of producing gas streams of known moisture content are tabulated in table 6 . Iristruments suitable for use as secondary standards are listed in table 7 . These instruments are characterized by good precision, long term repeatability and oredictable behavior. Methods for establishing fixed points are shown in table 8 .

The calibration and testing of hygrometers may be approached in either of two weys. An instrument or method that has a firm theoretical basis and is capable of giving highly accurate and reproducible measures of water vapor content is chosen as a standard. The hygrometer is calitrated by direct comparison wi th the standard when both instruments simultaneously are exposed or ewhiected to the same humidities. Alternativeiy, atmospheres of known humidity are produced and controlled by generators which operate predictably in accordance with known laws of physics. The hygrometer then is exposed to atnospheres of known water vapor content or the gas of known humidity is fed to the instrument under test. Similarly, fixed points of known humidity are produced by such chemical systems as saturated salt solutions, water-glycerin solutions and water-sulfuric acid solutions. A hygrometer is then exposed to the atmosphere over the chemical syster.

Table 3. Haterials sovered by ASTM standards requiring conditioning or contrcl of cabinets or rooms

\begin{tabular}{|c|c|c|}
\hline $\begin{array}{l}\text { Hydraulic corents } \\
\text { Concre:e } \\
\text { Soil-tituminous mix:ures } \\
\text { Fibertoard } \\
\text { Gyosum } \\
\text { Gypsum products } \\
\text { plaster products } \\
\text { plastics } \\
\text { Paper } \\
\text { Plastic flims } \\
\text { Asphali-treated papers } \\
\text { Asphalt-treated feits } \\
\text { Flexible sheets } \\
\text { Paper Spoducts } \\
\text { Shipoing sontainers } \\
\text { Packages }\end{array}$ & $\begin{array}{l}\text { Carboxymethylcellulose } \\
\text { ifmber } \\
\text { Electrical insulating materials } \\
\text { Yeneer } \\
\text { Plywood } \\
\text { Glued veneer constructions } \\
\text { Adhestve bords } \\
\text { Dried adhesive solids } \\
\text { Solid and corrugated fiberboard } \\
\text { hooc-based fiber and particle } \\
\text { panel materials } \\
\text { Wood oreservatives } \\
\text { hood } \\
\text { Wood-based materlals } \\
\text { Structural insulating roof deck }\end{array}$ & $\begin{array}{l}\text { Fiberooard nafl-base sneatning } \\
\text { Metal preservatives } \\
\text { Coal } \\
\text { Finishes on metal substrates } \\
\text { Paints on wood } \\
\text { hood fumiture lacouers } \\
\text { Coatings for plasties } \\
\text { Fire cords } \\
\text { Cord fabries } \\
\text { Knit goods } \\
\text { Industrfal fflament yarns } \\
\text { Textile products } \\
\text { Textfles } \\
\text { Textile fibers } \\
\text { Han-cade staple fibers }\end{array}$ \\
\hline
\end{tabular}

iable 4. Organizations having standards, speciffeations, or procedures involving humidity or moisture measurement and controi

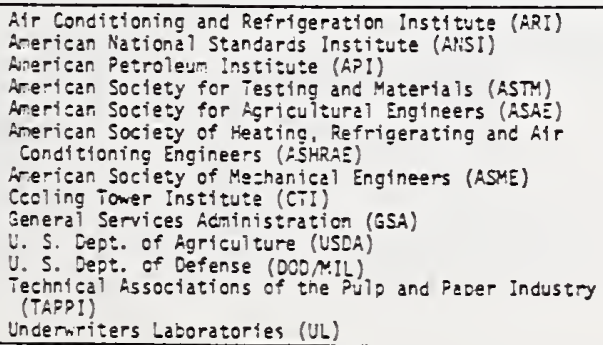

In:emational Crganizatior for Standardization (ISGi Intemational Electrotechrical Camission (IEC) U. S. DeDt. Of Comeres (DOC/NOAA) Horld Meteorological Organization ( $k \times 0)$ British Siandards Institute (BSI) Assosiation of Official Analytical Chemists (AOAC) Anerican Association of Cereal Chemists (AACC) Amerfcan Associaticn of Brewing Cherifs ts (AMBC) soard of Grain Comissioners for Carada corn Industries Peseareh Founca:ion Society of Public Analysts and Coher Anelytical Cnemists (Britian) Association Francaise de fiomaliza:ion (AFNOR) Intemational Organization of Legal Metrclogy (O:Ly) 
Table 5. Absolute methods of hunidity measurement

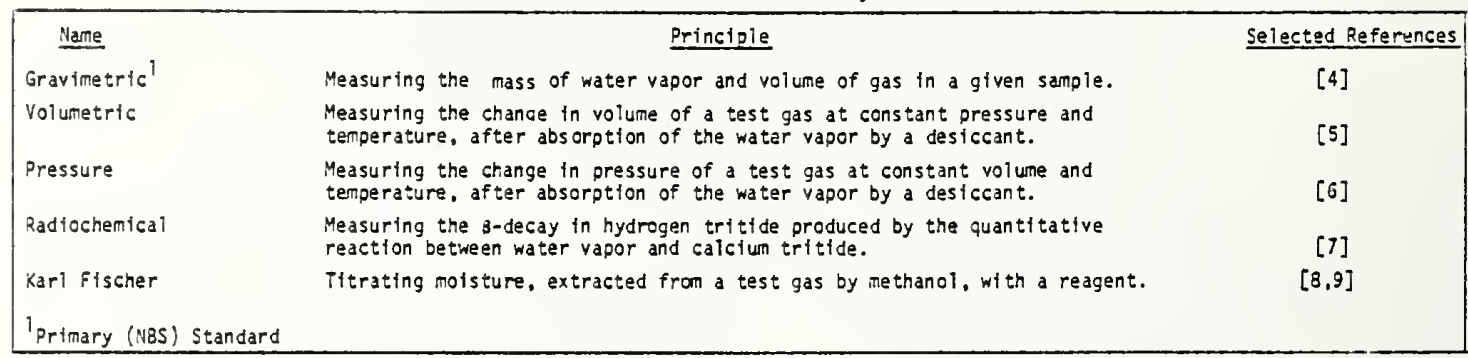

Tabie 6. Humfdity generators

\begin{tabular}{|c|c|c|}
\hline Name & Principle & Selected References \\
\hline Two-pressure ${ }^{1}$ & $\begin{array}{l}\text { isothemally saturating a gas stream at an elevated pressure and then } \\
\text { expanding it to a lower ftxed pressure. }\end{array}$ & {$[10-13]$} \\
\hline Two-tempera ture & $\begin{array}{l}\text { Isobarfcally saturating a gas stream at a low temperature and then waning it } \\
\text { to a higher fixed temperature. }\end{array}$ & [14-18] \\
\hline Recirculating & Two-temperature system with continuaus recirculation of the gas stream. & {$[19-21]$} \\
\hline Combtned streans & Mixtng two gas streams, one dry and the other saturated. & [22] \\
\hline Oivided-flow & $\begin{array}{l}\text { Dividing a dry gas stream into a prectsely known ratio, saturating one stream } \\
\text { whtle keeping the second dry. then cambining the two. }\end{array}$ & [23-25] \\
\hline Vapor transmission & $\begin{array}{l}\text { Passing a gas stream on one side of a water vapor permeable membrane, the other } \\
\text { stde of the membrane being exposed to liquid water. }\end{array}$ & {$[26-27]$} \\
\hline Vapor diffusion & $\begin{array}{l}\text { Passing a gas stream on one side of a flxed restriction through which water vapor } \\
\text { diffuses fran a liquld source. }\end{array}$ & [28] \\
\hline $\begin{array}{l}\text { Catalytic chemical } \\
\text { reaction } \\
1 \text { NBS factlity }\end{array}$ & $\begin{array}{l}\text { Analytfcally reacting oxygen and hydrogen to form water, in the presence of a } \\
\text { catalyst. }\end{array}$ & [29] \\
\hline
\end{tabular}

Table 7. Secondary humidity standards

\begin{tabular}{|c|c|c|}
\hline Name & Principle & Selected References \\
\hline Dew-polnt hygrometer & Measuring the temperature at which dew or frost forms. & {$[30,31]$} \\
\hline Pneunatic bridge 1 & Measuring the pressure drop across a critical flow nozzle bridge. & {$[32,33]$} \\
\hline Asptrated Psychrometer & Measurting the drop in temperature of water due to evaporation $\ln$ an open system. & {$[34,35]$} \\
\hline $\begin{array}{l}\text { Adiabatte saturation } \\
\text { psychrometer }\end{array}$ & $\begin{array}{l}\text { Measurfing the drop in temperature of water due to evaporation in a closed } \\
\text { system. }\end{array}$ & [36] \\
\hline Coulonetris hygrometer & Measuring the current occuring during the electrolysis of absorbed water. & {$[37-46]$} \\
\hline Mfcrowave hygrometer ${ }^{1}$ & Measuring the refractive index at nicrowave frequency. & {$[47-49]$} \\
\hline 1 NBS deve lopment & & \\
\hline
\end{tabular}

Table 8. Fixed humidtty points

Name

Saturated salt solutions water-glycerol solutions

Water-suifuric acid solutions

Patred-hydrate

\section{Principle}

Selected References

Estabilishing an equilforium humidity over a saturated salt solution.

Estabitshing an equflibrium humidtty over a water-glycerol solution of known concentratton.

Establishing an equilibrium humidf ty over a water-sulfuric acid solution of known concentration. Establishing an equilfbrium humidity over a system of pail red salt hydrates. 
There is a major division between the instrumentation intended for measuring humidity and that for measuring moisture. The instruments and methods utilized for humidity measurement are designed primarily for operation in the gas phase; those utilized for moisture measurement are designed primarily for handling liquids or solids. Instruments of the first category are classified as hygrometers, those of the second category as moisture meters. Because there is a relationship between the equilibrium water vapor content in the atmosphere surrounding a material and the moisture content of that material, hygrometers can and often are used to infer the moisture content of materials.

The methods, instruments and

procedures that have been used for humidity and moisture measurements encompass a diversity of physical and chemical principles $[55,56]$. They range in complexity from simple mechanical, pneumatic, or electrical devices to involved, complicated and sophisticated systems. It is possible, however, to classify humidity instruments into six broad groups as shown in table 9. Each of these broad groups contains a number of general methods that differ significantly in operating principles. Each general method, in turn, can have subcategories and variations.

The essential point to keep in mind is that there is no one or two universally accepted methods or instruments that will suffice for most measurements; rather, a method or instrument is chosen because it represents a compromise of performance characteristics, commercial availability, cost, etc. that are important for a given application. Manufacturers of humidity instruments and controls are listed in Appendix C. Although this appendix was compiled from several sources it may not necessarily be complete. There is some overlap since some manufacturers produce several types of instruments and controls.

Hoisture measuring instruments also can be classified into six groups based on broad principles of operation as shown in table 10. Manufacturers of moisture meters and controls are given in Appendix D. Although this appendix was compiled from several sources it may not be complete. One critical feature of the moisture measurement system is that nearly all of the continuously indicating devices are empirical in nature. Hot only is each instrument dependent on a calibration, but each calibration is different for each material, and varies with the chosen reference standard. There are four absolute methods, outlined in table 11 that sometimes are used as reference standards. These methods often yield divergent results. A basic difficulty arises from the vagueness of the meaning of water content. Water in a material may be physically adsorbed on the surface, chemically bonded as in a hydrate, condensed within the capillaries, or trapped in interstitial spaces.

Which forms of water are present and which forms should be measured depend on the characteristics, behavior and use of a given material. The various methods, procedures and techniques of measurement, including those chosen as reference standards, do not necessarily detect al1, or even the same kinds and quantities, of the identifiable forms of water. Thus there is a lack of uniformity and consistency in this measuring system.

The typical industrial calibration procedure is to remove samples of materials from a process line under operating conditions, to forward these to a laboratory, and to use a reference standard for determining the moisture content. The indication of the moisture meter on the process line is thus related to the moisture content as measured by the reference standard.

Economically, the measurement instrumentation industry for humidity and moisture is estimated to have an annual sales volume in the range $\$ 35-70$ million (see section $3.1 .2)$.

\subsubsection{Reference Data.}

The physical properties of the pure water substance are utilized as the primary reference data of the measurement system. There are a large number of properties of water, alone and as a component of a chemical system, yet there is no single source of critically evaluated reference data for use in the humidity and moisture measurement system; rather, there are a number of different compilations which do not always agree with each other or with the best available data. Appendix E gives an indication of the types and extent of these data. It shows in which of several important compilations certain selected reference data may be found. It also identifies a limited number of special data sources. These compilations are identified by the acronyms given below and at the bottom of the appendix. 
Table 9. Classification of humidtty measurements

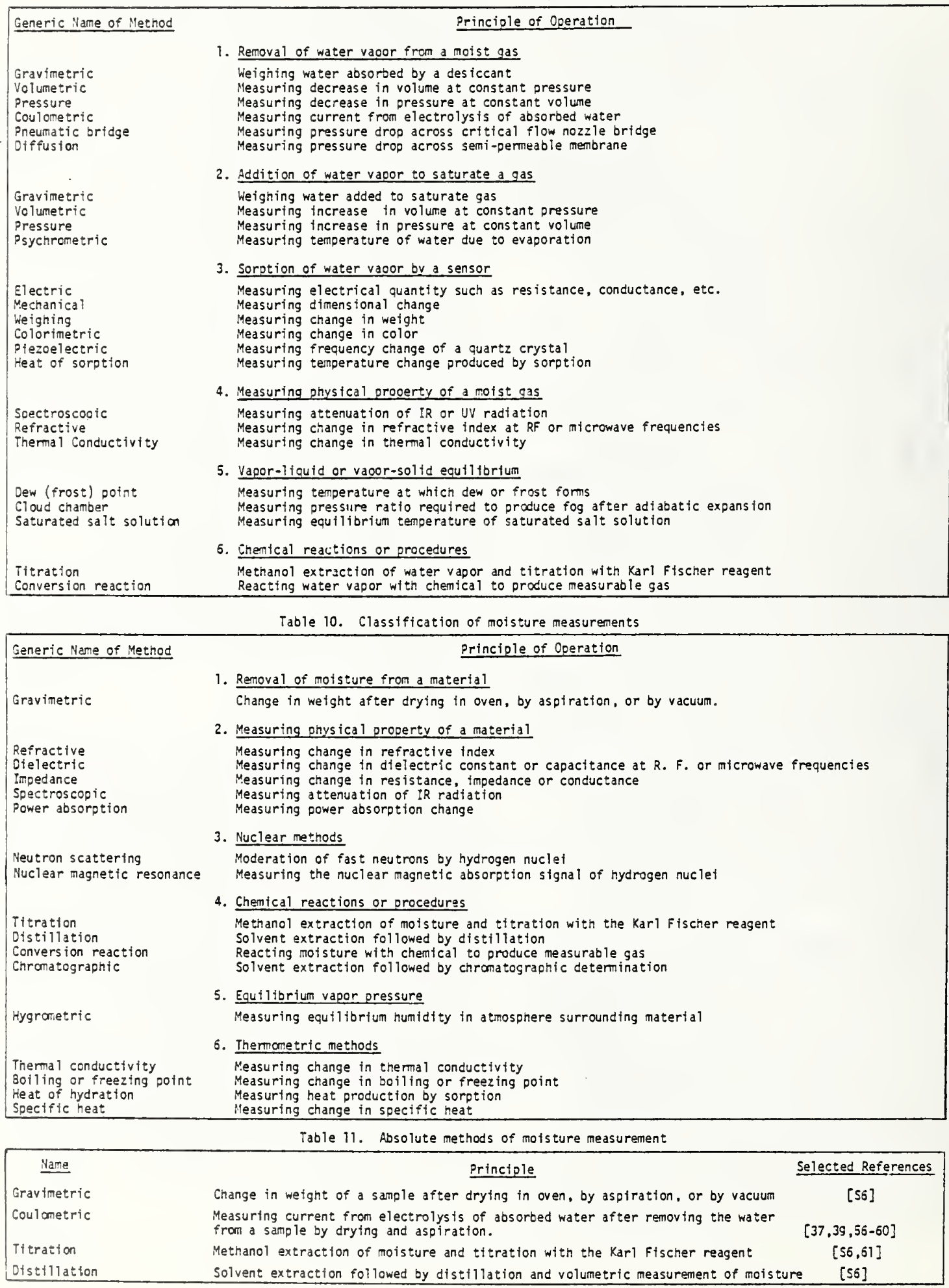


The International Critical Tables (ICT) [62] contain an extensive collection of data on the properties of water. These tables were published in 1928 and, unfortunately, have not been revised since then. However, because of the breadth of coverage the tables continue to be useful. The Landolt-Bornstein Tabellen (LBT) [66] contain a comparable coverage that reflect some updating due to the occassional issuance of revised editions. The most complete and exhaustive collection of data, as of 1940, is given in Dorsey's "Properties of Ordinary WaterSubstance" (D) [72]. Several monographs [87-89] have been published recently but these are intended primarily to relate the properties of water to its structure rather than present best values. The Handbook of Chemistry and Physics (HCP) $[65]$ is a useful source of a wide range of reference data. New editions are published periodically.

The formulations of Goff and Gratch (GG) [73-75] yield a consistent set of evaluated reference data on the low-pressure properties of water and moist air. These formulations were adopted in 1947 by the Twelfth Conference of Directors of the International Meteorological Organization and by the Internationa 1 Committee on Psychrometric Data in 1949 [75]. Tables of data based on the Goff and Gratch formulations are included in the ASHRAE Guide (AG) [67], in the Smithsonian Meteorological Tables (SMT) [64] and in the International Meteorological Tables (IMT) [63].

Critically evaluated properties of water are tabulated in great detail in various steam tables (ST) [68-71]. Although these tables include some values at low pressures, which are of interest in the humidity and moisture field, most of the data pertain to the high pressure domain for use in steam power technology. Hilsenrath (H) [76] has compiled a group of tables on the thermal properties of several gases, including steam and air.

\subsubsection{Reference Materials.}

Pure water is a well characterized substance with accurately determined properties of all its phases, of its transitions from phase to phase, and of its synthesis and dissociation. Water from naturally occurring sources is categorized as ordinary water and has a reasonably fixed isotopic composition [90]. Ordinary water which meets the specifications of the American Chemical Society (ACS) for reagents [91] is adequately pure to be used as a standard reference material. Deionization or distillation or both often suffices to produce such pure water. Fortunately, deionization and distillation are processes that are performed routinely in many laboratories so that pure ordinary water is readily available. The essential link between water and its use for calibration of a measuring device is a technique, procedure, or apparatus, such as a humidity generator, that mixes water as vapor or liquid with a second component to produce a homogeneous mixture of known water vapor or moisture content.

Saturated aqueous salt solutions, water-glycerin solutions, and water-sulfuric acid solutions when prepared from reagent grade chemicals meeting ACS specifications [91], form characterized chemical systems which can be used for performing humidity calibrations, that is, they yield fixed points of humidity. These chemical systems are prepared by the user. Saturated salt solutions are prepared and maintained easily without the need of using analytical procedures whereas the constituents for water-glycerin solutions and water-sulfuric acid solutions must be measured carefully and monitored frequently to ensure that the desired concentration is obtained and remains constant. When proper procedures are followed these solutions produce predictable water vapor contents in the ambient atmospheres within closed and sealed containers.

Manufacturers of several moisture meters have attempted, with limited success, to devise artificial standard reference materials for calibration purposes. The Agricultural Narketing Service of the U.S. Department of Agriculture (USDA) issues grain samples, primarily to its field offices, 1 icensed inspectors and repair service facilities, for use in checking the accuracy of the instrument officially approved for measuring moisture in grain. These samples are part of a measurement assurance program which determines whether field instruments are in compliance with USDA specifications. To avoid bias the operator of the instrument is kept unaware of the moisture content of the samples. He reports his measurements to an issuing office where they are compared to similar measurements on a part of the same sample. 


\subsubsection{Science and People.}

Humidity and moisture measurements are so diverse and pervasive in science, technology, industry and commerce that many people are involved in making and using such measurements. These people form a diffuse and heterogeneous group They interact with each other only in narrow technical fields. For example, instrumentation engineers in the petrochemical industry will exchange information at meetings of the Analysis Instrumentation Division of the Instrument Society of America (ISA). Meteorologists will attend one or more of the numerous conferences sponsored by the American Meteorological Society (Ails) at which humidity measurements and their application to meteorological problems are discussed. Similarly, air conditioning engineers seek information on humidity from their peers at meetings of the American Society of Heating, Refrigerating and Air Conditioning Engineers (ASHRAE). Those concerned with measurements of moisture in grain and other agricultural oroducts attend meetings of the American Society of Agricultural Engineers (ASAE). People in disciplines as unrelated as these have little occasion to interact with each other even though the instrumentation they use or the problems they must solve have common roots.

These and similar professional societies sponsor meetings, conferences or symposia at which one or more sessions are sometimes arranged on humidity and moisture measurement. Infrequently, there are mul tidisciplinary conferences devoted exclusively to humidity and moisture. These are so few they can be cited. November 25,1921 , a meeting on hygrometry was held at the Imperial College in London. The papers were published subsequently in the Proceedings of the Physical Society of London [92]. On June 25-27, 1959. the Institut Francais des Combustibles et de L'Energie held a conference in France on moisture in gases and materials. During 1961 , the International Union of Testing and Research Laboratories for Materials and Structures (RILEM) conducted a "Seminar by Correspondence on Measurement of Moisture in Materials and Structures." A Russian conference on humidity was held in Leningrad in June 1962. In 1963, two U.S. Government agencies, the National Bureau of Standards and the Weather Bureau (now the National Weather Service), and three technical societies, the American Society of Heating, Refrigerating and Air Conditioning Engineers, the Instrument Society of America, and the American Meteorological Society jointly sponsored an International symposium on
Humidity and Moisture which was attended by over 850 scientists and engineers from around the world [93]. During 1971 , the International i"easurement Confederation (IMEKO) held a conference on moisture in Hungary [94].

There is no single discipline which furnishes the educational base for the people who provide for or use humidity and moisture measurements. The general science or engineering student is exposed to the humidity and moisture measurement system during his university career only peripherally, if at all. Meteorologists and air conditioning engineers either during their college training or in the practice of their professions are destined to be exposed to the concepts of humidity, particularly psychrometry, but not necessarily to the measurement process itself, because the concepts are essential elements of their disciplines. Chemists and chemical engineers, similarly, may come into contact with humidity and moisture because the measurement or control of these quantities is critical to many manufacturing processes and to the behavior and performance of most materials, but measurement information and experience generally is obtained informaliy and empirically.

There is an extensive literature on humidity and moisture, but this is scattered throughout many scientific and technical journals. Monographs in English, through few in number, are available $[93,95,96]$. Monographs have also been published in Germany [97-99], Poland [100], Romania [101], Russia [102] and Japan [103].

\subsection{Realized Measurement Capabilities}

Humidity measurement capabilities run the gamut from parts per billion (ppb), that is, es sentially bone dry conditions, to 100 percent water vapor at ambient temperatures from $-100^{\circ} \mathrm{C}$ to over $100^{\circ} \mathrm{C}$ and at ambient pressures from $5000 \mathrm{~Pa}(1 / 20 \mathrm{~atm})$ to over $10^{7} \mathrm{~Pa}$ $(100 \mathrm{~atm})$. Water vapor contents in the ppb range of, say, air at standard atmospheric pressure correspond to frost points of $-100^{\circ} \mathrm{C}$. Smaller trace quantities do not appear to have any technological, commercial or scientific importance. When the water vapor content reaches 100 percent, then, obviously, we no longer have a mixture but only the pure phase. The major industrial importance of pure phase water vapor is in steam technology. Measurements of temperature and pressure will specify steam completely, so that the instrumentation normally used for humidity is no longer necessary and, in large measure, is not applicable. 
Although measurements of the humidity of atmospheric air are the most frequent, it must be emphasized that measurements are also made in such technologically important gases as argon, helium, neon, nitrogen, oxygen, carbon dioxide, methane, sulfur dioxide, butane, ethane, refrigerants, chlorine, propane and natural gas. The ranges and uncertainties of a number of selected instruments and methods, in air at standard atmospheric pressure, are shown in figure 3. These curves represent the upper Iimits of accuracy that are currently attainable. The state of the art may be sumarized by stating that the best of the commercial instruments have uncertainties of the order of $11 / 2$ to $2 \%$ of the reading which, under ideal conditions, may sometimes decrease to $1 \%$. Most instruments tend to have uncertainties of the order of 3 to $5 \%$. The highest possible accuracy, $(0.1 \%)$ can only be realized by the gravimetric hygrometer [4].

\subsection{Dissemination and Enforcement Network}

\subsubsection{Central Standards Authorities.}

The Organic Act of 1901 (15 United States Code 271-286) as amended authorizes the lational Bureau of Standards to undertake "the custody, maintenance, and development of the national standards of measurement, and the provision of means and methods of making measurements consistent with those standards, including the comparison of standards used in scientific investigations, engineering, manufacturing, commerce, and educational institutions with the standards adopted or recognized by the Government." The Act further authorizes NBS to undertake a number of specific activities including "the construction of physical standards; the testing, calibration, and certification of standards and standard measuring apparatus; the study and improvement of instruments and methods of measurements"; and "cooperation with the States in securing uniformity in weights and measures laws and methods of inspection."

In pursuance of these legal responsibilities, NBS has provided and disseminated within the United States the national standards for the seven base and more than thirty derived units of measurement, including humidity. There has been no comparable INBS involvement with moisture although several of the States have requested assistance particularly in the measurement of moisture in grain.

\subsubsection{State and Local Offices of Weights and Heasures.}

In recent years several of the grain producing states have established legal requirements for the accuracy of moisture in grain instruments. Maryland and North Carolina have voluntary programs for checking a field instrument with a moisture meter in a licensed laboratory. Virginia in 1956 established a semivoluntary system for checking moisture meters. In 1959 Nebraska established through its State Railway Commission a system for testing grain moisture meters using selected moisture meters as standards and referencing these, in turn, against the gravimetric (air oven) method. Indiana, Illinois and Iowa have adopted similar systems. California is attempting to establist procedures for testing moisture meters by using artifacts which check electrical characteristics. Other states have under consideration legislative proposals or weights and measures regulations which will establish accuracy requirements and test procedures for checking moisture meters.

\subsubsection{Standards and Testing Laboratories and Services.}

Humidity measurement accuracy and consistency are disseminated to the ultimate user, either by a direct link with the Mational Bureau of Standards, by an indirect chain involving one or more stages of transfer, or by the employment of standard reference materials. Out of a list of 199 standards laboratories both in Government and the private sector, surveyed by the ilational Conference of Standards Laboratories [104], 104 resoonded that they had the capability of performing humidity calibrations. of these, 5 offered measurement services only for primary standards, 74 for secondary or test instruments and 25 for both. The customers of 49 laboratories were 1 imited to their parent or organizations, 54 provided services to others in special cases, and 18 indicated that services were available on a fee basis.

Most of the instrument companies maintain in-house facilities for calibration and production line testing and quality assurance. A few of these will perform calibrations for a fee on instruments not of their own manufacture. 


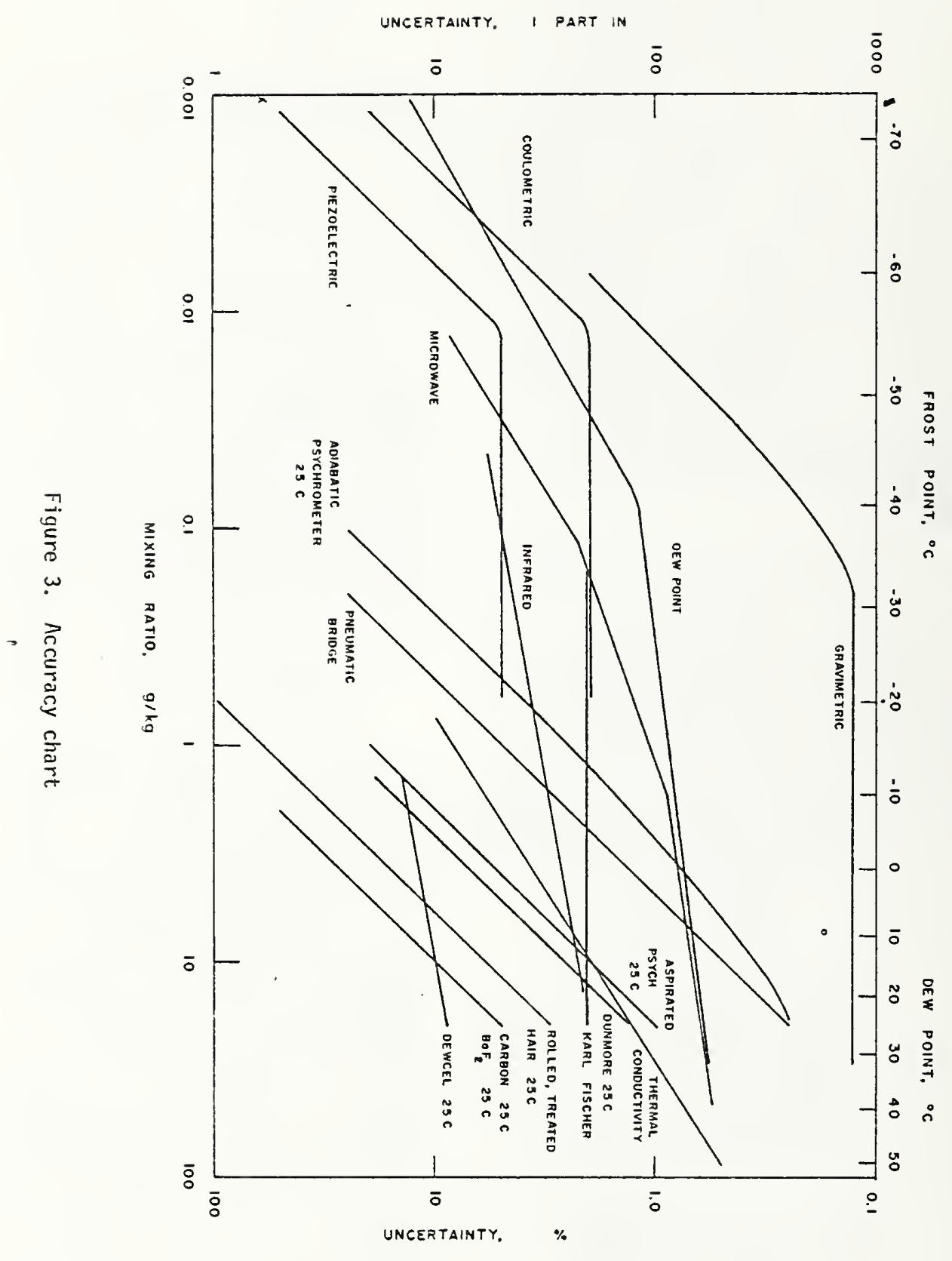


Several Government agencies (e.g., U.S. Army Electronics Command, Air Force Cambridge Research Laboratories, Naval Research Laboratory, National Weather Service) have R \& D laboratories with humidity calibration and testing capabilities. These laboratories provide measurement services to operational units within their agency (for example, the Air Weather Service) who make routine observations to fulfill mission-oriented needs. These laboratories sometimes design or develop new or improved instruments which then are procured from commercial sources.

The U.S. Government has inspection services and testing laboratories [105] which have the capability of performing a broad range of tests on almost every type of material or device purchased for official use. The items are procured under ililitary or Federal specifications which sometimes prescribe conditioning in humidity cabinets or rooms, and measurements of humidity or moisture content. Facilities and instrumentation are needed for these purposes.

\subsubsection{Regulatory Agencies.}

The U. S. Department of Agriculture (USDA) under the Grain Standards Act of 1916 as amended has the legal responsibility for establishing standards covering grain moving in interstate and foreign commerce; it also has similar responsibilities for beans, lentils, peas and rice under the Agricultural Marketing Act of 1946. Acting under these legistative mandates, the USDA, through the Grain Division of the Agricultural Marketing Service has promulgated official standards for the moisture determination in grain and related agricultural products [106] to be used in verifying the accuracy of new and modified moisture meters and for preparing new or verifying old conversion charts for the USDA official moisture meter. Measurement accuracy is disseminated by offically approved moisture meters through a hierarchical system originating in a main office, devolving to regional offices and, finally, to licensed grain inspectors.

The USDA does not exercise jurisdiction at the State level. Since moisture content is, among other considerations, an essential ingredient in equity in the selling and buying of grain and related agricultural commodities, many States, generally through their official weights and measures organizations, are involved in checking the accuracy of moisture meters used in trade and commerce. It is traditional for these organizations to look to UBS for traceable standards, as well as for advice and guidance.

\subsection{Measurements Transactions Matrix}

\subsubsection{Analysis of Suppliers and Users.}

The interrelationships between the users and suppliers of the National Measurement System for humidity and moisture are shown in the transactions matrix of table 12. Every user is also listed as a supplier of measurement services even though in some cases this duality of function is questionable or does not exist. The suppliers have been identified by Standard Industrial Classification (SIC) codes. The appearance of only one symbol in any transaction box (that for the primary magnitude quantity) implies that NBS knowledge is sufficiently limited that the author preiers not to make an estimate of the subsidiary information items. A question mark (?) indicates NBS has insufficient knowledge on which to make a judgment. Where estimates of the magnitude, rate of change, importance or adequacy of the transaction have been inserted into a matrix element, these are coded in accordance with the key given. It must be emphasized that these entries are judgments on the part of the author. It would be prudent to view them with caution, to consider them primarily as educated guesses.

\subsubsection{Highlights re Major Users.}

See Sections 2.4 and 3.1 and table 13.

3. IMPACT, STATUS, AND TRENDS OF MEASUREMENT SYSTEH

\subsection{Impact of Measurements}

\subsubsection{Functional, Technological, and Scientific Applications.}

A few examples may serve to demonstrate the influence of humidity on man, his environment, and his technology. Atmospheric water vapor affects the probability and amount of precipitation, the formation of dew, the prediction of damaging frosts to agriculture, the potential danger of forest fires, the development of thunderstorms, the presence of sharp refractive index gradients which cause anomalous propagation of electromagnetic energy at microwave frequencies; it affects evaporation from rivers, lakes, reservoirs, oceans, and snow and ice surfaces; and it affects the transpiration of moisture from soils, growing crops, and forests. Man's comfort and health 
Table 12. Oirect measurements transactions matrix

\begin{tabular}{|c|c|c|c|c|c|c|c|c|c|c|c|c|c|c|c|c|c|c|}
\hline $\begin{array}{l}\text { OIRECT } \\
\text { MEASUREMENTS } \\
\text { TRANSACTIONS } \\
\text { MATRIX FOR } \\
\text { HUMIOITY ANO } \\
\text { MOISTURE }\end{array}$ & 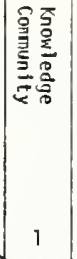 & 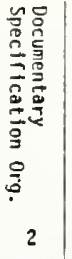 & 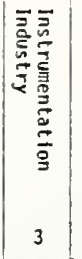 & $\begin{array}{l}\text { N } \\
B \\
5 \\
4\end{array}$ & 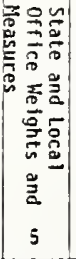 & 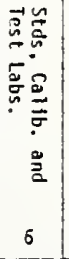 & 용 & 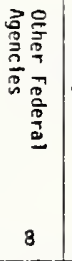 & 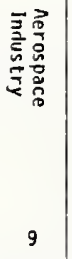 & 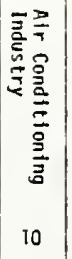 & 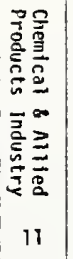 & 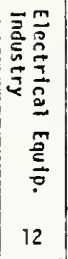 & 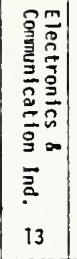 & 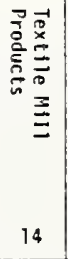 & 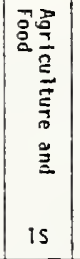 & 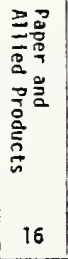 & 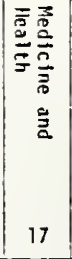 & 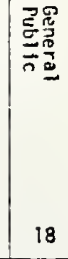 \\
\hline $\begin{array}{l}\text { Knowledge } \\
\text { Community }\end{array}$ & $2{ }^{2}{ }^{1}$ & 2,1 & $2,1 / 2$ & $2^{1}$ & 2 & $?$ & $2^{12}$ & 2,1 & 2 & 3 & 2 & $?$ & 2 & 2 & 3 & 2 & 1 & 1 \\
\hline $\begin{array}{l}2 \text { Oocumentary } \\
\text { Specification } \\
\text { Organizations }\end{array}$ & $22^{2}$ & ${ }_{3}{ }^{1}$ & $2^{1 / 2}$ & $1^{2}$ & $22^{2}$ & 3 & 3 & 2 & 3 & 21 & $3^{12}$ & 3 & $2^{2} 3^{12}$ & 2,1 & $32^{3}$ & $4^{1}$ & $?$ & 0 \\
\hline $\begin{array}{l}3 \text { Instrumentation } \\
\text { Industry SIC } \\
3822.3823 .3822 \\
\end{array}$ & $2^{2}$ & $23^{1.2}$ & $2^{2} 2^{1 / 2}$ & $2^{1}$ & 34 & 4 & 4 & 3 & 2 & 31 & $3^{2} 12$ & 21 & 2 & 2 & $2^{3} 4^{2}$ & 3 & 1 & 1 \\
\hline NBS & $\left|\begin{array}{ll}2 & 3\end{array}\right|$ & $22^{3}$ & $3_{3}^{3} 1 / 2$ & 21 & $\mid \begin{array}{lll}3 & 2^{3}\end{array}$ & 331 & 31 & 23 & 33 & 21 & 212 & 2,2 & 2,2 & $21^{2}$ & $24^{3} 2$ & 211 & 1 & 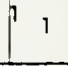 \\
\hline $\begin{array}{l}5 \text { State and Local off. } \\
\text { Wetghts and Measures }\end{array}$ & $?$ & 212 & $2^{2} 2^{2} 2$ & 13 & 2 & $?$ & $?$ & 1 & 0 & $?$ & $?$ & $?$ & $?$ & $?$ & $?$ & $?$ & $?$ & 0 \\
\hline $\begin{array}{l}\text { Standards, Calib. } \\
\text { and Test Labs. }\end{array}$ & 1 & 22 & $?$ & $1^{2}$ & $?$ & 2 & 2 & 2 & 2 & 2 & $?$ & $?$ & $?$ & $?$ & $?$ & $?$ & 0 & 0 \\
\hline 000 & 2 & $21 /$ & $3_{3} 3^{1 / 2}$ & $2^{1}$ & $?$ & 3 & 3 & 2 & 2 & $?$ & $?$ & $?$ & 2 & $?$ & $?$ & $?$ & $?$ & 0 \\
\hline $\begin{array}{l}8 \text { Other Federal } \\
\text { Agencies }\end{array}$ & 2,1 & $3^{1 / 2}$ & 2,12 & $2^{1}$ & 2 & 1 & 2 & 2 & 3 & 2 & $?$ & $?$ & 3 & $?$ & 3 & 2 & 2 & 1 \\
\hline $\begin{array}{l}\text { Aerosoace industry } \\
\text { SIC } 372,376\end{array}$ & $2 \begin{array}{ll}2 & 1 \\
& 1\end{array}$ & 1 & \begin{tabular}{lll|l}
2 & & $1 / 2$ \\
2 & $N$
\end{tabular} & 1 & $?$ & $?$ & 2 & 2 & 2 & $?$ & $?$ & $?$ & $?$ & $?$ & $?$ & $?$ & $?$ & 0 \\
\hline $\begin{array}{l}10 \text { Air Condition } \\
\text { Industry SIC 3S8S }\end{array}$ & 3 & 2 & 2,1 & 1 & $?$ & $?$ & 2 & 3 & 1 & $24^{1}$ & $?$ & 2 & 2 & 4 & $2_{2}^{?} 4^{?}$ & 4 & $\int_{2}^{3} 3$ & $2^{?} 3^{?}$ \\
\hline $\begin{array}{l}11 \text { Chem and Allied Prod } \\
\text { Industry SIC } 28\end{array}$ & $?$ & 1 & 1 & 1 & $?$ & $?$ & 2 & 2 & $?$ & $22^{1}$ & $?$ & $?$ & $?$ & $?$ & $?$ & $?$ & $?$ & 0 \\
\hline $\begin{array}{l}12 \text { Elect Equipment } \\
\text { Industry } \\
\text { SiC } 361.362,364\end{array}$ & $?$ & 1 & $i$ & 1 & $?$ & $?$ & $?$ & $?$ & $?$ & $?$ & $?$ & $?$ & $?$ & $?$ & $?$ & $?$ & $?$ & 0 \\
\hline $\begin{array}{l}13 \text { Electron and Comm } \\
\text { Industry SIC } 366 \text {, } \\
367\end{array}$ & $?$ & 2 & 2 & 1 & $?$ & $?$ & 2 & 2 & 2 & $?$ & $?$ & $?$ & $?$ & $?$ & 2 & $?$ & $?$ & 0 \\
\hline $\begin{array}{l}14 \text { Textlle Mili } \\
\text { Products SiC } 22\end{array}$ & $?$ & 2 & 1 & 0 & $?$ & $?$ & $?$ & $?$ & $?$ & $?$ & $?$ & $?$ & $?$ & $?$ & $?$ & $?$ & $?$ & 0 \\
\hline $\begin{array}{l}15 \text { Agriculture and } \\
\text { Food SIC 01,20 }\end{array}$ & 2 & 2 & \begin{tabular}{ll|l|l}
2 & 2 & 2 \\
& 2 & 2
\end{tabular} & $2^{2}$ & $?$ & $?$ & 2 & 3 & $?$ & $?$ & $?$ & $?$ & $?$ & $?$ & $?$ & $?$ & $?$ & 0 \\
\hline $\begin{array}{l}16 \text { Paper and Allied } \\
\text { Products SIC } 26\end{array}$ & $?$ & 2 & 2 & 2 & $?$ & $?$ & $?$ & $?$ & $?$ & $?$ & $?$ & $?$ & $?$ & $?$ & 3 & $?$ & $?$ & 0 \\
\hline $\begin{array}{l}17 \text { Medficine and Health } \\
\text { SIC } 80\end{array}$ & $2 i$ & 1 & 0 & 0 & $?$ & $?$ & $?$ & $i$ & & 11 & $?$ & 27 & $?$ & $?$ & 2 & $?$ & $3^{3} 3^{2}$ & 2 \\
\hline $\begin{array}{l}18 \text { General } \\
\text { Public }\end{array}$ & 0 & 0 & 0 & 0 & 0 & 0 & 0 & 0 & 0 & 0 & 0 & 0 & 0 & 0 & 0 & 0 & 0 & 0 \\
\hline
\end{tabular}

XEY TO MATRIX ENTRIES

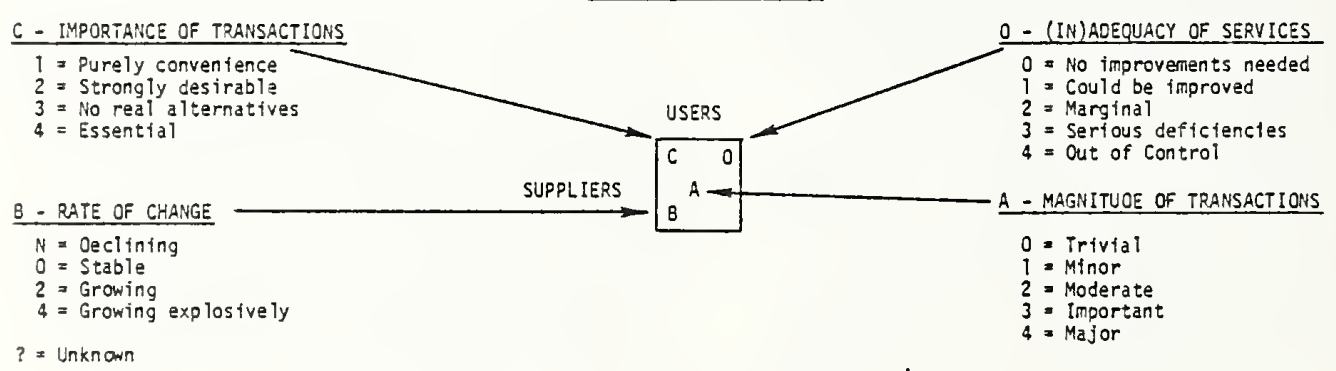


are related to the humidity of his environment. The water vapor content in sealed aircraft cabins, pressure suits and space vehicles must be closely controlled. Certain lung disorders are alleviated by controlled atmospheres of humidity.

Fabrics, wood, plastics, grains, processed foods, dry cereais, and tobacco are subject to mold, rot and high moisture gain at high humidities. Iron and steel will rust in the presence of moisture. Industrial processes such as heat treating, sintering, brazing and welding of metals and alloys; dry cleaning; textile, plastics and paper fabrication; and catalytic operations in petrochemical industries are seriously affected by humidity. In fact few quantities affect so many diverse materials, processes, and industries as humidity and moisture. Table 13 contains a list of selected disciplines, industries and technologies where humidity measurement and control exert a significant impact. The processes, operations or phenomena affected by humidity or moisture and the nature of the impact or reasons for measurement are included.

The amount of water in a material is of vital commercial concern, particularly in buying, selling and shipping where costs are related to weight. It has a pronounced effect on the properties of materials. It must be controlled for uniformity in mass production processes, for achieving formulation and process economies, and for the conservation of fuels and energy in drying processes. It greatly influences the quality of many products. Hoisture in food products for example, affects taste, color and preservation.

\subsubsection{Economic Impacts--Costs and Benefits.}

ivo attempt has been made to assess the overall economic impact that the measurement and control of humidity and moisture has on the technology, industry and commerce of the United States. Rather, we have selected examples to illustrate specific cases of this impact. Where economic data in dollars are known, they are included.

We examine first, the instrumentation industry. The annual shipments of the identifiable humidity and moisture instrumentation are estimated to total about $\$ 35$ milition. This may be conservative because it does not include data or estimates from all manufacturers listed in Appendices $C$ and $D$. However, it is unlikely that the annual shipments exceed $\$ 70$ million. (See Appendix A).
This instrumentation, supplemented by laboratory methods and procedures, supports the manufacture of a broad range of products. Table 14 contains a partial list of important products, together with the appropriate Standard Industrial Classification (SIC) codes and the values of the industrial shipments for 1973. This totals over $\$ 150$ billion. It should not be inferred that all these products could not be manufactured wi thout humidity and moisture measurement and control. On the other hand, without such instrumentation, product quality would be impaired or the cost of production would increase or both.

Let us narrow our focus on one industrial component of the economy, the process industries, where such parameters as temperature, flow, liquid level, pressure, chemical composition, density, viscosity, humidity and flow are monitored and regulated. The relative order of occurrence of various types of measurements in the process industries, as given by Perry [107] is shown in table 15 . It is estimated that of the total number of such measurements humidity constitutes 3.5 percent and moisture 0.7 percent. To some extent, these estimates for humidity and moisture do not entirely reflect their relative importance for measurements often are not made because of inadequate instrumentation.

Table 16 outlines some industrial processes where humidity control is important, together with the optimum relative humidity for the successful operation of the process.

We turn now from the industrial sector of the economy to the agricultural sector and look at grains and oilseeds. These crops (wheat, corn, soybeans, oats, barley, etc.) must be dried to a moisture content of 13 to 15 percent or lower. This is done, generally, with artifical heat, involving the consumption of fuel energy (usually propane). Income and profits depend on moisture content. Excess moisture leads to spoilage and loss in quality. Too much drying is wasteful because of high fuel costs. Also it contributes to the National energy crisis. The price of grain is reduced if the moisture exceeds a designated value. The farmer suffers a loss if the moisture content drops below the designated value because there is more grain per bushel without a compensating increase in price. It is therefore to his disadvantage if the measurement of the moisture is not accurate. For example, in 1971 the production of corn was 5.6 billion bushels for which the average season 
Table 13. Impact of humidity measurement and control on selected disciplines, industries and technologies

\begin{tabular}{|c|c|c|}
\hline $\begin{array}{l}\text { Discipline, Industry } \\
\text { or Technology }\end{array}$ & $\begin{array}{l}\text { Process, Operation, or } \\
\text { Phenomenon }\end{array}$ & $\begin{array}{l}\text { Nature of Impact or Reason for } \\
\text { Measurement or Control }\end{array}$ \\
\hline Aerospace & $\begin{array}{l}\text { Operating supersonic wind tunnels. } \\
\text { Controlling capsule environment, iffe } \\
\text { support systems, sealed cabins, and } \\
\text { pressure suits. } \\
\text { simulating high altitude and space } \\
\text { conditions in environmental chambers. } \\
\text { studying planetary atmospheres from } \\
\text { orbiters and landers. } \\
\text { Measuring upper air humidity. } \\
\text { Dehydrating contaminated fuel tanks of } \\
\text { jet aircraft and detecting moisture in } \\
\text { jet fuel. }\end{array}$ & $\begin{array}{l}\text { Characterizing or controlling environment of test } \\
\text { section. Preventing condensation due to pressure changes. } \\
\text { Removing and recovering water vapor from expired breath. } \\
\text { Ensuring aviator and astronaut survival and comfort. } \\
\text { At high altitude and space temperatures extreme dryness } \\
\text { is essential to prevent icing and freezing. } \\
\text { Moisture is an indicator of possible life. } \\
\text { Humidity affects aircraft icing, condensation trafls, } \\
\text { Carburetor icing, visibility, fog, clouds, precioitation, } \\
\text { uv transmission, ozone depletion, propagation of } \\
\text { electromagnettc energy, and ballistic trajectories. } \\
\text { Moisture can cause freeze-up of fuel lines. }\end{array}$ \\
\hline Air Conditioning & $\begin{array}{l}\text { Controlling humidity of home, office, } \\
\text { factory, public building, theaters, } \\
\text { hospltals, etc. } \\
\text { Controlling environment of librarles, } \\
\text { museums, art gallerles, archives. } \\
\text { Controlling environment of data } \\
\text { procassing and computer facillties. } \\
\text { Performance testing of humidifiers, } \\
\text { dehumidifiers, heat pumps, cooling towers. } \\
\text { Monttoring air to cooling colis. } \\
\text { Controlling humidity of greenhouses. } \\
\text { Ventilating deep mines. }\end{array}$ & $\begin{array}{l}\text { Human comfort and health. } \\
\text { Preservation; high humidity causes mildew and rot; dry } \\
\text { atmosphere makes materials brittle and subject to cracking } \\
\text { and dry deterioration. } \\
\text { Computer components, punch cards, etc. are sensitive to } \\
\text { humidity. } \\
\text { Efficiency and rating depend on humidity. } \\
\text { Freeze-up can occur at high humidity. } \\
\text { High humidity helps plant growth. } \\
\text { Human heaith and comfort. }\end{array}$ \\
\hline Atomic and Iluclear & $\begin{array}{l}\text { lieasuring moisture in high pressure } \\
\text { reactor cooling gases. } \\
\text { Operating high temperature nuclear reactors }\end{array}$ & $\begin{array}{l}\text { Presence of moisture indicates leakage of water into } \\
\text { reactor. } \\
\text { Moisture in helium causes graphite corrosion leading to } \\
\text { unsafe operation. }\end{array}$ \\
\hline $\begin{array}{l}\text { Biology and } \\
\text { Medicine }\end{array}$ & $\begin{array}{l}\text { Studying environmental stress on human } \\
\text { subjects. } \\
\text { Treating obstructive lung disorders. } \\
\text { studying water vapor boundary layers in } \\
\text { biological systems. } \\
\text { Studying plant transpiration. } \\
\text { Studying insect physiology. } \\
\text { Measuring water potential in plants. } \\
\text { Controlling humidity in hospitais. }\end{array}$ & $\begin{array}{l}\text { Evaporative heat loss is dependent on humidity. } \\
\text { High humidfty helps maintain mucous bianket moist which, } \\
\text { in turn, permits it to continuously regenerate and sustain } \\
\text { drainage. } \\
\text { Boundary layer is transition zone for heat and vapor } \\
\text { diffusion. } \\
\text { Transpiration rate affects growth. } \\
\text { Health and growth is related to humidity. } \\
\text { Affects growth. } \\
\text { Required for treatment of certain diseases and ailments; } \\
\text { for care of premature babtes; to prevent explosions due } \\
\text { to anesthetic gases. }\end{array}$ \\
\hline Ceramies & $\begin{array}{l}\text { Storing, processing and curing of raw } \\
\text { materials and finished products. }\end{array}$ & $\begin{array}{l}\text { Moisture affects manufacturing process and quality of } \\
\text { finfshed product. }\end{array}$ \\
\hline
\end{tabular}


Table 13, cont'd. Impact of humidity measurement and control on selected disciplines, industries and technologies

\begin{tabular}{|c|c|c|}
\hline $\begin{array}{l}\text { Discipline, Industry } \\
\text { or Technology }\end{array}$ & $\begin{array}{l}\text { Process, Operation, or } \\
\text { Phenomenon }\end{array}$ & $\begin{array}{l}\text { Nature of Impact or Reason for } \\
\text { Measurement or Control }\end{array}$ \\
\hline Chemical & $\begin{array}{l}\text { Manufacturing chlorine. } \\
\text { Manufacturing compressed gas. } \\
\text { Manufacturing aviators breathing oxygen. } \\
\text { Liquefying gases. } \\
\text { Maintaining cotimum water content in dry } \\
\text { cleaning solvent. } \\
\text { Manufacturing of hygroscopic materials. } \\
\text { Manufacturing of drugs and } \\
\text { pharmaceuticals. } \\
\text { Manufacturing and storing liquid sulfur } \\
\text { dioxide. }\end{array}$ & $\begin{array}{l}\text { Platinum catalyst used is water soluble. } \\
\text { Too little moisture in gaseous } \mathrm{CO}_{2} \text { makes ice too brittle, } \\
\text { fractures too easily; too much moisture causes freeze-up } \\
\text { of valves. } \\
\text { Moisture reacts to form waste actd. } \\
\text { Molsture may condense during compression. } \\
\text { Moisture causes freeze-up of valves and components. } \\
\text { Moisture causes freeze-up of valves and components. } \\
\text { Too little water results in poor removal of water-solutle } \\
\text { soil; too much causes wrinkling of fabrics, loss of creases } \\
\text { and pleats, shrinking of fabrics. } \\
\text { Dry atmosohere essential for handling. } \\
\text { Moisture affects quality and shelf } 1 \text { ife. } \\
\text { Moisture, even in small quantities, makes liquid sulfur } \\
\text { dioxide highly coriosive. }\end{array}$ \\
\hline Drying & $\begin{array}{l}\text { Monitoring moisture content of effluent } \\
\text { stream from drying column. } \\
\text { Kiln srying of lumber. } \\
\text { Drying instrument air. } \\
\text { Drying plant air for pneumatically } \\
\text { operated valves, tools, equioment. }\end{array}$ & $\begin{array}{l}\text { Columns can be maintained at highest efficiency if } \\
\text { regeneration is initiated just before or at instant of } \\
\text { breakthrough of water. } \\
\text { Prevents warping and deterioration. } \\
\text { Necessary for effective operation of pneumatic control } \\
\text { instruments in process industries; to prevent } \\
\text { condensation, freeze-up, and corrosion. } \\
\text { To prevent condensation, freeze-up and corrosion. }\end{array}$ \\
\hline Electrical & $\begin{array}{l}\text { Assembling lamp bulbs. } \\
\text { Insulating transfomers with dielectric } \\
\text { liquids. } \\
\text { Sorotion of moisture by electrical } \\
\text { insulating materials. } \\
\text { Electrolytic corrosion. } \\
\text { Assembling motors, colls and transformers. }\end{array}$ & $\begin{array}{l}\text { Moisture in inert gas used in filling bulbs decomposes } \\
\text { allowing oxygen to oxidize filaments and shorten life. } \\
\text { Moisture causes breakdown, arcing and corrosion. } \\
\text { Causes reduction in resistivity and voltage breakdown. } \\
\text { Causes deterioration. } \\
\text { Low humidity required to prevent moisture sorption. }\end{array}$ \\
\hline $\begin{array}{l}\text { Electronics and } \\
\text { Communications }\end{array}$ & $\begin{array}{l}\text { Manufacturing transistors. } \\
\text { Operating microwave and radar equipment. } \\
\text { Operating infra-red dection devices. } \\
\text { Maintaining telephone cables, TV cables. } \\
\text { Monitoring hermetically sealed electronic } \\
\text { modules. } \\
\text { Monitoring radar sites. }\end{array}$ & $\begin{array}{l}\text { Moisture causes decay of semi-conductor material; } \\
\text { encapsulation is accomplished in ory } \mathrm{N}_{2} \text {, He, or } \mathrm{A} \\
\text { atmospheres. } \\
\text { Radio propagation is affected by atmospheric humidity; } \\
\text { moisture in wave guides produces corrosion and reduces } \\
\text { power handing capability. } \\
\text { Performance of IR detectors is dependent on humidity along } \\
\text { path. } \\
\text { Humidfty of gas surrounding cables affects operation; must } \\
\text { be dry to prevent electrical shortage from moisture } \\
\text { infiltration. } \\
\text { High humidity often causes fallure of electronic components } \\
\text { and assemblies. } \\
\text { To prevent condensation on components. }\end{array}$ \\
\hline $\begin{array}{l}\text { Fibrous, Organic } \\
\text { and Plastic } \\
\text { Materials }\end{array}$ & $\begin{array}{l}\text { Manufacturing olastic materials. } \\
\text { Manufacturing of textiles. }\end{array}$ & $\begin{array}{l}\text { Moisture affects quality. } \\
\text { Humidity control essential for proper operation } \\
\text { of macninery, regain control, elimination of static } \\
\text { electricity, reduction of dust. }\end{array}$ \\
\hline
\end{tabular}


Taole 13, cont'd. Impact of humidity measurement and control on selected disciplines, industries and technologies

\begin{tabular}{|c|c|c|}
\hline $\begin{array}{l}\text { Oiscipline, Industry } \\
\text { or Technology }\end{array}$ & $\begin{array}{l}\text { Process, Operation, or } \\
\text { Phenomenon }\end{array}$ & $\begin{array}{l}\text { Nature of Impact or Reason for } \\
\text { Measurement or Control }\end{array}$ \\
\hline $\begin{array}{l}\text { Food and } \\
\text { Agricul ture }\end{array}$ & $\begin{array}{l}\text { Orying and storing grain, cereals, rice, } \\
\text { flour, starch. } \\
\text { Malntaining moisture control of agricultural } \\
\text { products during harvesting, handling, } \\
\text { processing, packaging and transportation. } \\
\text { oistilling alcohol, liquor. } \\
\text { Manufacturing and processing food (e.g., } \\
\text { bakery products, beer and ale, butter, } \\
\text { candy, chocolate, crakers and biscuits, } \\
\text { macaroni and spaghetti, meat and meat } \\
\text { products, cerezls, dehydrated foods). } \\
\text { Manufacturing tobacco products. } \\
\text { Incubating poultry. }\end{array}$ & $\begin{array}{l}\text { High moisture can cause mold and rot, heating, insect } \\
\text { damage, sprouting; sale price afiected by moisture content; } \\
\text { improper drying results in loss of quality. } \\
\text { Molsture content can cause deterioration or loss of quality } \\
\text { and quantity, market price affected by moisture content. } \\
\text { Low humidity important where grains are ground. } \\
\text { Humidity affects quality, taste, texture, etc.; high } \\
\text { humidity leads to spoilage. } \\
\text { Humidity control necessary for optimum processing. } \\
\text { Proper humidity insures optimum growth. }\end{array}$ \\
\hline Marine & $\begin{array}{l}\text { Mothballing naval vessels. } \\
\text { Storing shipboard cargo. } \\
\text { Orying high pressure alr on naval ships, } \\
\text { submarines for missile launching, etc. }\end{array}$ & $\begin{array}{l}\text { High humidity causes rust and oxidation of metal structures } \\
\text { instruments components. } \\
\text { High humidity can result in condensation on cargo. } \\
\text { Icing can cause locking and blocking of valves, orifices } \\
\text { and filters. }\end{array}$ \\
\hline Metallurgy & $\begin{array}{l}\text { Welding titanium, stainless steel and } \\
\text { other alloys. } \\
\text { Heat treating, carburizing, nitriding. } \\
\text { dry cyaniding; polishing, brazing, } \\
\text { sintering, annealing of metals and alloys. } \\
\text { Storage of ferrous metals. } \\
\text { Measuring moisture in sinter mix, coke and } \\
\text { iron ore for blast furnaces. }\end{array}$ & $\begin{array}{l}\text { High water content in } A \text { and He causes oxidation of } \\
\text { weld. } \\
\text { Water vapor in gases (usually } \mathrm{H}_{2} \text { and } \mathrm{H}_{2} \text { ) or furnace } \\
\text { atmospheres can decompose yielding oxygen which causes } \\
\text { cxidation of metal surfaces; causes decarburization of } \\
\text { surface; affects carbon potential. } \\
\text { High humidity causes rust. } \\
\text { Moisture content affects quality and product efficiency } \\
\text { in manufacturing. }\end{array}$ \\
\hline Me teorology & $\begin{array}{l}\text { Atmospheric monitoring from land stations, } \\
\text { vessels, radiosondes, aircraft. } \\
\text { Stratospheric and mesospteric measurements. } \\
\text { Evaporation from oceans, lakes, reserviors, } \\
\text { rivers, snow surfaces, forests, prairies, } \\
\text { and other land surfaces. } \\
\text { Water vapor turbulence. } \\
\text { Cloud seeding. } \\
\text { Monitoring humidity in forests. }\end{array}$ & $\begin{array}{l}\text { Used for climatology, weather prediction, dynamics of } \\
\text { atmosphere, physics of clouds, weather modification. } \\
\text { Weather prediction, atmospheric circulation, IR } \\
\text { transmission; climatic impact from photochemical reactions; } \\
\text { radio propagation. } \\
\text { Affects water budget. } \\
\text { Affects evaporation and transpiration. } \\
\text { Heather modification. } \\
\text { Prediction of forest fires dangers. }\end{array}$ \\
\hline $\begin{array}{l}\text { Missiles, Munftions, } \\
\text { Rockets, Ordnance }\end{array}$ & $\begin{array}{l}\text { Monitoring missile tank gas. } \\
\text { Measuring atmospheric huntdity. } \\
\text { Monitoring solid propellent mixing rooms. } \\
\text { Monitoring missile sites. } \\
\text { Controlling humidity around powder type fuses } \\
\text { Storing liquid rocket propellants. }\end{array}$ & $\begin{array}{l}\text { Too much moisture causes freeze-up bleed valves. } \\
\text { Required for computing trajectorles. } \\
\text { Ory atmosphere required for quality control and to } \\
\text { prevent corrosion. } \\
\text { Prevention of condensation on components. } \\
\text { RH is held to } 1 \text { percent so that moisture content is } \\
\text { controlled to } 0.1 \text { percent by weight; more molsture } \\
\text { gives slower timing. } \\
\text { Small quantities (few tenths of } 1 \text { percent) can cause } \\
\text { corrosion rates high enough to cause structural or } \\
\text { component failure. }\end{array}$ \\
\hline
\end{tabular}


Table 13 cont'd. Impact of humidity measurement and control on selected disciplines, industries and technologies

\begin{tabular}{|c|c|c|}
\hline $\begin{array}{l}\text { Discipline, Industry } \\
\text { or Technology }\end{array}$ & $\begin{array}{l}\text { Proess, Coeration, or } \\
\text { Phenomencn }\end{array}$ & $\begin{array}{l}\text { Nature of Impact or Peason for } \\
\text { Measurement or Control }\end{array}$ \\
\hline Petro-chemical & $\begin{array}{l}\text { Transporting, transmitting and storing } \\
\text { natural gas and liquified natural gas. } \\
\text { Honitoring moisture level of hydrogen and } \\
\text { butane feed lines in butane isomerization } \\
\text { process. } \\
\text { Monitoring water vapor in recycle hydrogen } \\
\text { streams of catalytic reforming processes } \\
\text { for producing high-octane gasoline. } \\
\text { Purging and blanketing operations with } \\
\text { dry gas. } \\
\text { Liquid pnase drying of such chemicals as } \\
\text { benzine, toluene, zylene, butane, propane, } \\
\text { trichiorethylene, refrigerants, methyl } \\
\text { chloride. }\end{array}$ & $\begin{array}{l}\text { High moisture content will cause freeze-ufs below } 0^{\circ} \mathrm{C} \\
\text { and form hydrates which freeze above } 0^{\circ} \mathrm{C} \text {. } \\
\text { Moisture impairs catalyst life and activity. } \\
\text { Provides operational guidance during start-up, nomal } \\
\text { operation, test run and abnormal conditions. Moisture } \\
\text { poisons catalyst. } \\
\text { Reduces explosive hazards; prevents reaction of chemicais } \\
\text { with moisture. } \\
\text { Molsture inhibits drying. }\end{array}$ \\
\hline $\begin{array}{l}\text { Printing and } \\
\text { Photography }\end{array}$ & $\begin{array}{l}\text { Color printing and registering. } \\
\text { Letterpress printing, lithography and } \\
\text { rotogravure. } \\
\text { Manufacturing and storage of photographic } \\
\text { film anc paper. }\end{array}$ & $\begin{array}{l}\text { Precise ambient humidity control is essential for } \\
\text { controlifno paper dimensions to ensure correct } \\
\text { registering of successive colors in printing. } \\
\text { Humidity control minimizes problems of static electricity, } \\
\text { ink mist, expanding and contracting of paper with resultant } \\
\text { breaks, swelling or shrinxing of composition rollers. } \\
\text { Humidity control to insure optimum manufacturing conditions } \\
\text { and to insure maximum life. }\end{array}$ \\
\hline Refrigeration & $\begin{array}{l}\text { Manufacturing of refrigerant gases. } \\
\text { Manufacturing and assembiy of } \\
\text { refrigerating systems. }\end{array}$ & $\begin{array}{l}\text { Moisture will cause freezing-up of expansion valves in } \\
\text { compressor. } \\
\text { Moisture will cause operational failures due to freeze- } \\
\text { up of expansion valves and caolliary tubes; formation of } \\
\text { fce in evaporators, corrosion, flapper valve fallure, } \\
\text { damage to insulation. }\end{array}$ \\
\hline $\begin{array}{l}\text { Research, } \\
\text { Development and } \\
\text { Testing }\end{array}$ & $\begin{array}{l}\text { Testing of materials for water and water } \\
\text { vapor sorption (regain) and permeability } \\
\text { in solid, sheet, granular and powdered } \\
\text { form; includes foods, textiles, grains, } \\
\text { ceramics, concrete, buliding materiais, } \\
\text { rubber, olastics wood, wood products, } \\
\text { tobacco, etc. } \\
\text { Conditioning of materials, products, } \\
\text { instruments, devices in environmental } \\
\text { rooms, chambers, boxes, etc. } \\
\text { studies of diffusion, viscosity of moist } \\
\text { afr, rate of evaporation of water droplets, } \\
\text { sound absorption in gases, gemination of } \\
\text { mold spores, refractive index of air, etc. } \\
\text { Dry box testing. }\end{array}$ & $\begin{array}{l}\text { Moisture content affects performance, behavior, quality, } \\
\text { and use of materials. Penmeability detenmines effectiveness } \\
\text { as vapor barriers in pacxaging for moisture } \\
\text { sensitive materials. } \\
\text { Testing for conformance to specifications and standards. } \\
\text { Scientific data. } \\
\text { Materials, devices, components, etc. that are affected by } \\
\text { moisture are often tested in dry boxes. }\end{array}$ \\
\hline Soil & Measuring moisture content. & $\begin{array}{l}\text { Moisture content affects volume changes, which in :urn, } \\
\text { cause differential movenents of structures leading to } \\
\text { excessive cracking of floors, walls, and foundations; } \\
\text { moisture content important in watershed hydrology; moisture } \\
\text { affects safe current loading of buried cables; and moisture } \\
\text { content affects economic growth of croos. }\end{array}$ \\
\hline Storage & $\begin{array}{l}\text { Maintaining critical military } \\
\text { inventories, particularly of } \\
\text { moisture sensitive materials. } \\
\text { Monitoring dehydrated packaging. } \\
\text { Controling humidity in warehouses and } \\
\text { caves. } \\
\text { Controliing humidity in commercial storage } \\
\text { operations (e.g., beer fementation } \\
\text { rooms, meat storage, machine tools, } \\
\text { candy, food products, furs, furniture, } \\
\text { paper stock, chemicais). }\end{array}$ & $\begin{array}{l}\text { Many metallic, organic and synthettc materials quickly } \\
\text { deteriorate at high humidity due to rot, mildew and fungus } \\
\text { growth, particulariy in Pacific area and tropics. } \\
\text { Moisture infiltration causes sooilage, corrosion, etc. } \\
\text { Low humidity necessary to prevent deterioration. } \\
\text { To prevent deterioration and loss of product. }\end{array}$ \\
\hline Structure & $\begin{array}{l}\text { Moisture content and migration in walls, } \\
\text { roofs, etc. }\end{array}$ & $\begin{array}{l}\text { Determining origin of moisture (ground moisture } \\
\text { condensation, rain, etc.) necessary to elininate source. }\end{array}$ \\
\hline
\end{tabular}


Table 14. Industrial statistics on selected manufactured products for $1973^{*}$

\begin{tabular}{|c|c|c|}
\hline $\begin{array}{l}\text { SIC Codes } \\
(1967 \text { basis }) \\
\end{array}$ & Product & $\begin{array}{l}\text { Value of Industry } \\
\text { Shipments } \\
5 \text { Bilions }\end{array}$ \\
\hline $\begin{array}{l}1925 \\
2011 \\
2022 \\
2023 \\
2024 \\
2026 \\
2032 \\
2033 \\
2041 \\
2042 \\
2051 \\
2052 \\
2071 \\
2072 \\
2095 \\
21 \\
2521,31,61 \\
2647 \\
2812 \\
2813 \\
2816 \\
2818 \\
2819 \\
2821 \\
2831,33,34 \\
2841 \\
2851 \\
3011 \\
3069 \\
3585\end{array}$ & $\begin{array}{l}\text { Guided missles and space vehicles } \\
\text { Meat packing plant products } \\
\text { Cheese, natural and processed } \\
\text { Condensed and evaporated milk } \\
\text { Ice cream and frozen deserts } \\
\text { Fluid milk } \\
\text { Canned specialities } \\
\text { Canned fruits, vegetable preserves, jams and jellies } \\
\text { Flour and other grain mill shipments } \\
\text { Prepared feeds for animals and fowls } \\
\text { Bread and other baking products } \\
\text { Crackers and cookies } \\
\text { Candy and other confectionary products } \\
\text { Chocolate and cocoa products } \\
\text { Roasted coffee } \\
\text { Tobacco } \\
\text { Paper and board } \\
\text { Sanitary paper products } \\
\text { Alkalies and chlorine } \\
\text { Industrial gases } \\
\text { Inorganic pigments } \\
\text { Industrial organic chemicals } \\
\text { Industrial inorganic chemicals } \\
\text { Plastic materials and resins } \\
\text { Phanaceutical preparations } \\
\text { Soap and detergents } \\
\text { Paint and allied products } \\
\text { Tires and inner tubes } \\
\text { Rubber products } \\
\text { Air conditioning and cormercial and industrial }\end{array}$ & $\begin{array}{r}3.80 \\
24.15 \\
3.74 \\
1.73 \\
1.24 \\
9.14 \\
1.94 \\
4.39 \\
3.10 \\
9.64 \\
6.24 \\
1.83 \\
2.02 \\
.72 \\
2.49 \\
4.63 \\
11.50 \\
1.89 \\
.77 \\
.75 \\
.78 \\
10.33 \\
5.00 \\
5.53 \\
8.62 \\
3.33 \\
4.15 \\
5.44 \\
4.25\end{array}$ \\
\hline 4 & refrigeration equipment & $\frac{5.94}{\$ 150.08}$ \\
\hline
\end{tabular}

Table 15. Relative order of occurrence of various types of measurements in the process industries*

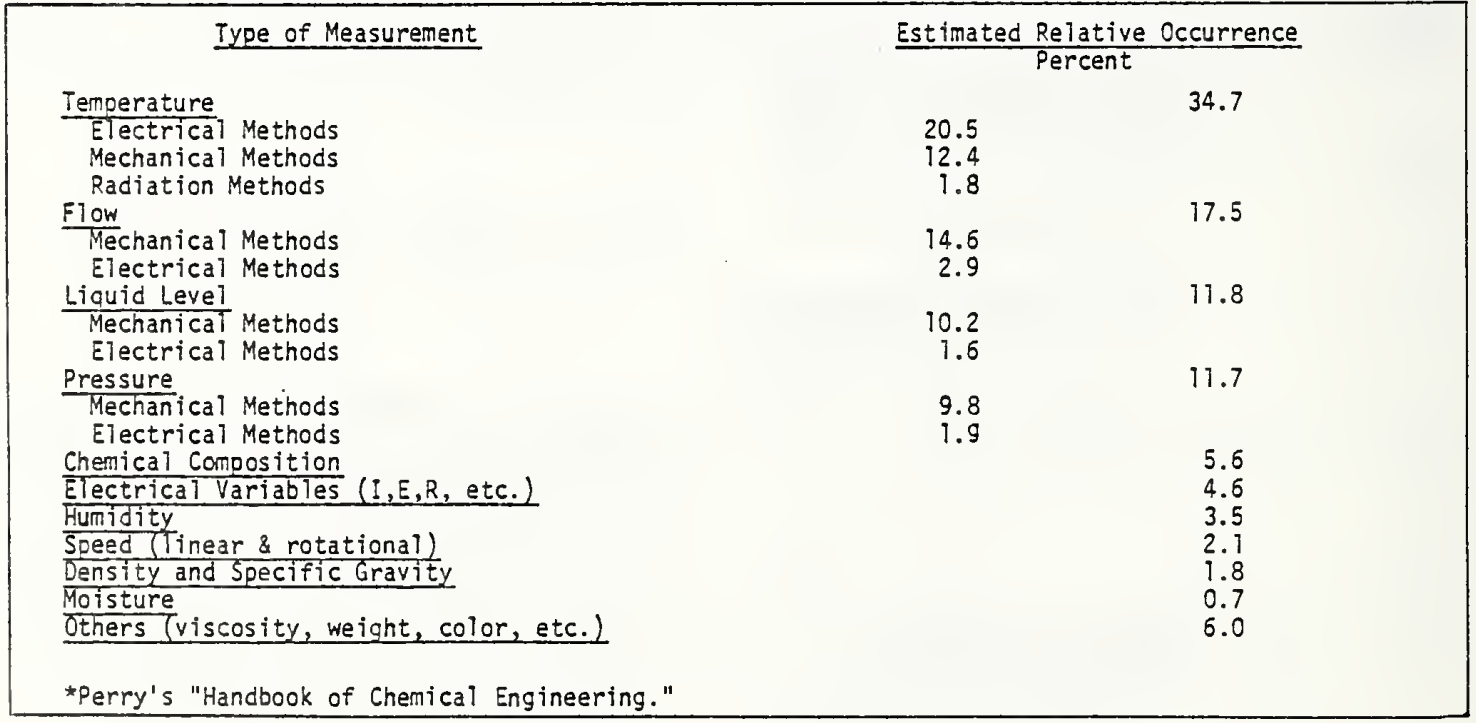


price paid the farmer was $\$ 1.08$ per bushel (SE.O billion). The reduction was 2 cents per tushel for each percent moisture over 15.5 percent. The loss (exclusive of added drying costs) for each percent moisture under 15.5 percent was 1.2 cents per bushel. A spot check in llovember 1968 in Iowa revealed that moisture meters commonly used for moisture measurement of grain varied as wuch as 3.4 percent in indicated moisture on the same samples. If this same pattern prevailed nationally, farmers could have suffered a loss of as much as \$341 million from excess moisture (or moisture indication) or a loss as wuch as \$228 million from excess drying (or low moisture indication). Reducing the uncertainty in moisture meters to 0.5 percent could have reduced the possible loss to $\$ 56$ million for excess moisture and to $\$ 34$ million for excess drying. Similar calculations can be made for the other grains. Data on the production and farm values of important grain and oilseed crops are given in table 17 for 1971 . It can be seen that moisture measurements supported agricultural crops in 1971 having a total farm value of at least 514.9 billion.

\subsubsection{Social, Human, Person-in-the-street Impacts.}

Anyone who has listened to a weather prediction on radio or $T V$, or who has read the latest forecast in his newspaper, has been exposed to the concept of humidity. He even may have in his home or office, a simple instrument which reads or controls the humidity of his environment. More likely he has no physical instrument but his body senses serve as a crude substitute. Hign sumer humidity imparts a damp or muggy feeling; low winter humidity imparts a dry and criso feeling. Physical effects in and around the home accentuate the physioiogical perceptions. When the humidity is high, drawers stick, foods become soggy and in winter, condensation appears on cold window paries. Again, in the winter, electric shocks from static charge on rugs or on upholstery in automobiles are certain signs of low humidity.

Air conditioning, in which humidity control plays a substantial role, is a common feature of public buildings, libraries, museums, art galleries, hospitals, ofices, and with increasing frequency, private homes. Sometimes when a residence has no air conditioning, the homeowner installs a humidifier to increase the humidity for health reasons (usually bronchial problems) or, perhaps, to improve the tonal properties of his piano; or he may install a dehumidifier to reduce the humidity, particularly in a basement where mildew and mold have a tendency to form when the humidity is high.

\subsection{Status and Trends of the System}

The measurement of very low water vapor contents is, at best, very crude. Yet there appears to be a need for making such measurements, particularly in the stratosphere and mesosphere, the petrochemical industry, nuclear reactor industry, compressed gases, and in planetary atmospheres. At the very high water vapor content end of the humidity domain good methods of measurement are not available. Instrumentation that is used over the mid-span of water vapor contents is designed primarily for ambient pressures of about $0.1 \mathrm{MPa}$ (1 atm) and for a narrow range of ambient temperatures. There is a deficiency in the technology of making humidity measurements at both very low and very high pressures, and with corrosive gases. In addition, at high pressures, information is needed on the enhancement* of water vapor in gases of technological importance. The assumptions of gas ideality can introduce large errors in the interpretation of instrument indications.

There is also a need for determining the frequency response or response time of instruments and sensors used for dynamic measurements. Current practice is to calibrate statically and to assume that this calibration will hold under rapidly fluctuating conditions. Within the measurement system there is only a limited capability for making response time studies, yet data of this kind are vitally needed, particularly for instruments and sensors used in radiosondes, rocket sondes and high speed aircraft.

*Erihancernent is the ratio of the concentration of saturated water vapor mixed with a gas to the concentration of pure phase saturated water vapor. For example, at $30^{\circ} \mathrm{C}$ and $10 \mathrm{MPa}$ there is 34 percent more vapor present in saturated a ir than is predicted solely by the ideal gas laws. 
Table 16. Relative humidity and temperature requirements for some industrial processes and products control*

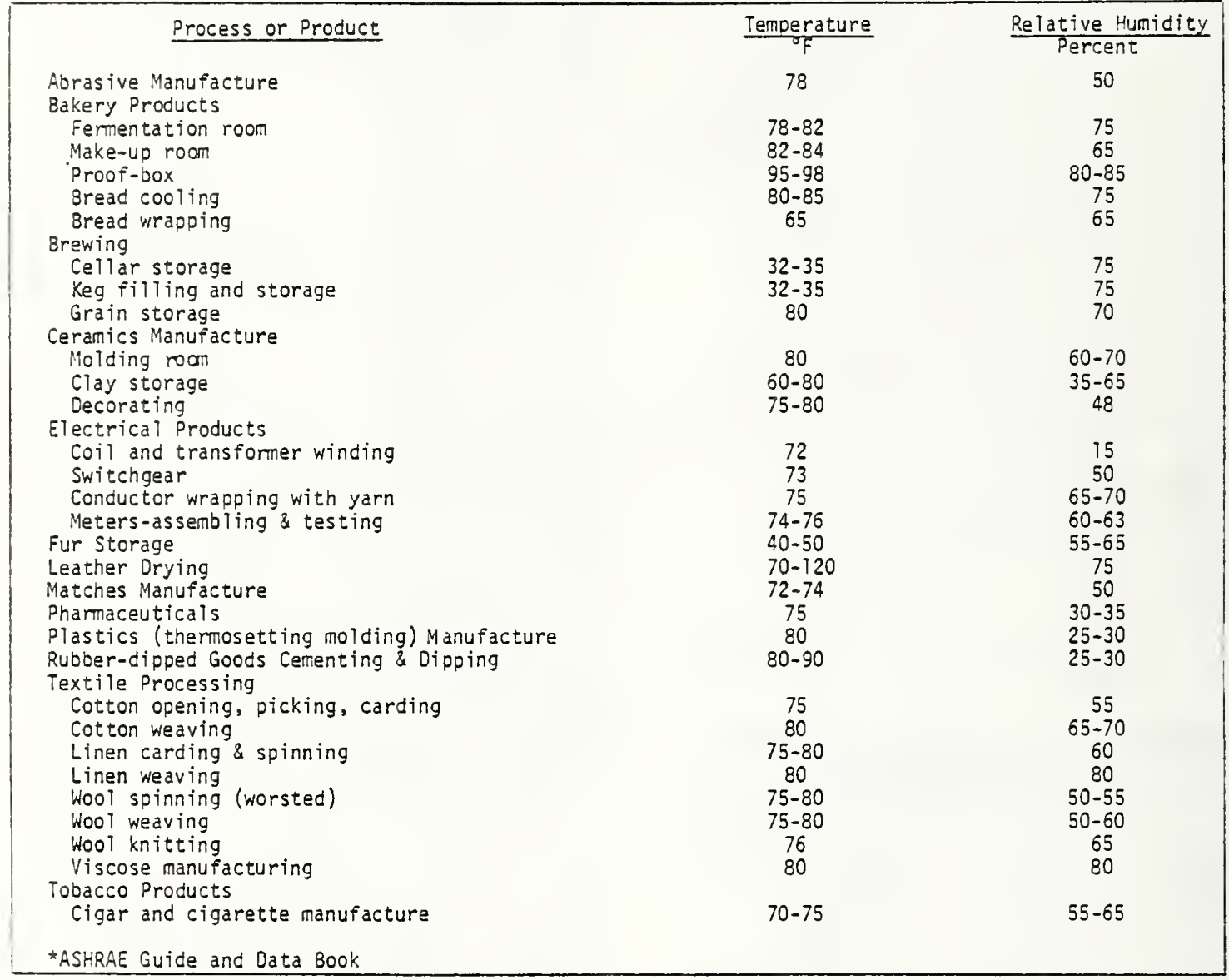

Table 17. Agricultural statistics on selected grain and oilseed crops for $1977^{*}$

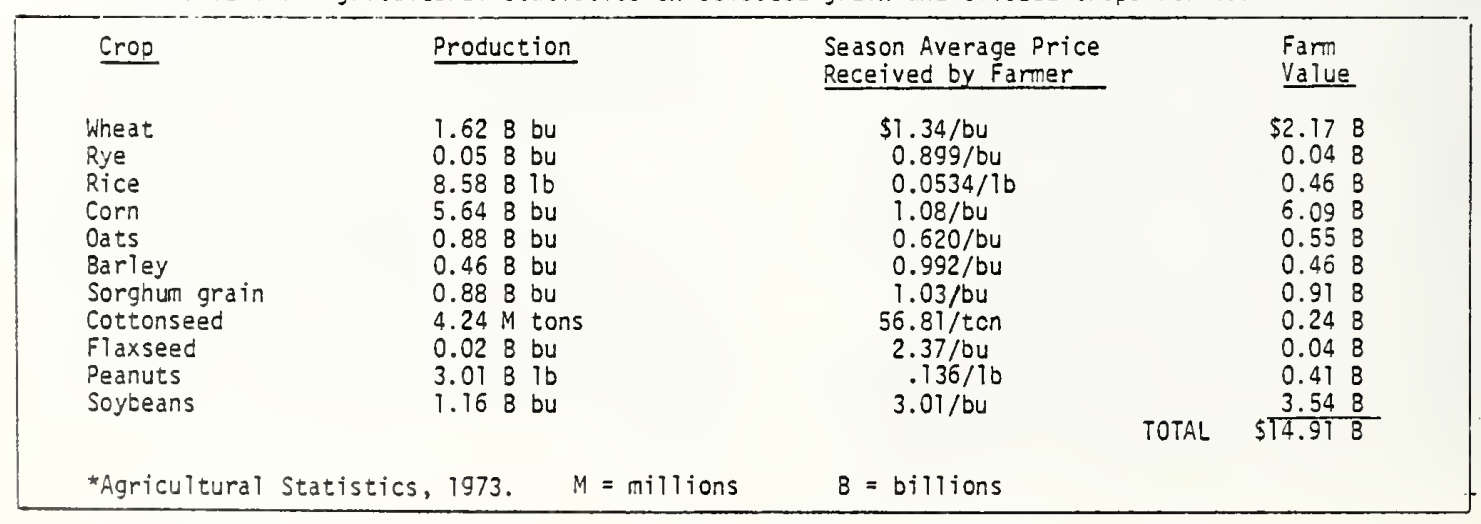


Hodern meteorological and aerologica? research of the atmosphere is moving rapidly towerd the use of passive measurement technioues. Sensors detect and integrate signa is which travel over long path lengths. Thus humidity is being detected from satellites, eireraft and balloons by infrared (IR) and Ul traviolet (UV) instruments. Unfortunately, there are no humidity calibration procedures that can check the accuracy of these instruments. It is obvious that as these instruments increase in sensitivity and frequency of use, and perhaps become synoptic tools, there will be an urgent need to validate their readings.

Humidity measurement and control for air conditioning in industrial operations, business establisiments, public buildings and entertainment centers is an accepted phenomenon of current American life. There is an accelerating trend toward the control of numidity in private homes for human comiort and health.

Many industrial processes are dependent for their successful operation on the crying of materials and products. Agricultura crops such as grains and oilseeds aiso are dried. In the past, with fuel or energy readily aviliable at low cost, empirical techniques for drying were adequate. Now, and in the foreseeable future, the continuous measurement and control of product noisture or of the ambient humidity will be of increasing concern in achieving optimum moisture content, high drying efficiency, and conservation of fuet and energy.

Consumerism is having an ever increasing effect on trade and commerce. This is reflected, in part, in regulations issued at national and local levels, requiring that product ingredients and even amounts be specified on the label. It is probable that in the future, the inclusion of the moisture content in specific commodities and products will be required on labels and that there may also be established mandatory limits for moisture content. There would, therefore, be a need for rapid methods of test and inspection. The field of moisture measurement would expand into new areas with direct and immediate impact on what the person-in-thestreet buys in his local store or supermarket.

\section{SURVEY OF NBS SERVICES}

\subsection{The Past - Historical Background}

The history of the involvement of the National Bureau of Standards in the humidity and moisture measurement system dates back, at least, to the early Twenties. The concern then and over the ensuing years was in the development of specialized instrumentation $[10,33,48,49,108-111,112-129]$, humidity cabinets and chambers [15,130-132] and environmental test rooms [133].

Late in the Thirties, the Bureau developed a small electrical humidity sensor for use in radiosondes $[116,117]$ which was adopted by the National Weather Service (then the Weather Bureau) and by the U. S. military metecrological services, and subsequently became an important industrial device. The evaluation of this sensor presented a new problem--that of devising a method and designing a chamber that could be used for calibrations at temperatures below freezing. This was the motivation, then, for the development of the first HBS precision humidity generator [24]. The continued need for better methods of calibration subsequentiy led to the design, development and construction of other generators $[12,19]$, to an interest and involvement in the entire field of humidity measurements, and to the establishment of facilities and competences that were, and still are,unique in the country.

As information on the availability of these facilities became known to other Government agencies, to industry, and to the scientific community, requests were received with increasing frequency for calibrations and tests on a variety of hygrometers. Initially, this work was restricted to Government agencies. However, with time it became apparent that there was a need for humidity standards and for supplying a calibration service not only to Government, but also to industry and other laboratories. This led to the development of a national reference standard [4] and of lesser order (transfer) standards $[32,36]$ for use by other laboratories, to investigating fixed points [50] and to the acceptance for calibration of instruments suitable for use as laboratory or plant standerds [134]. 


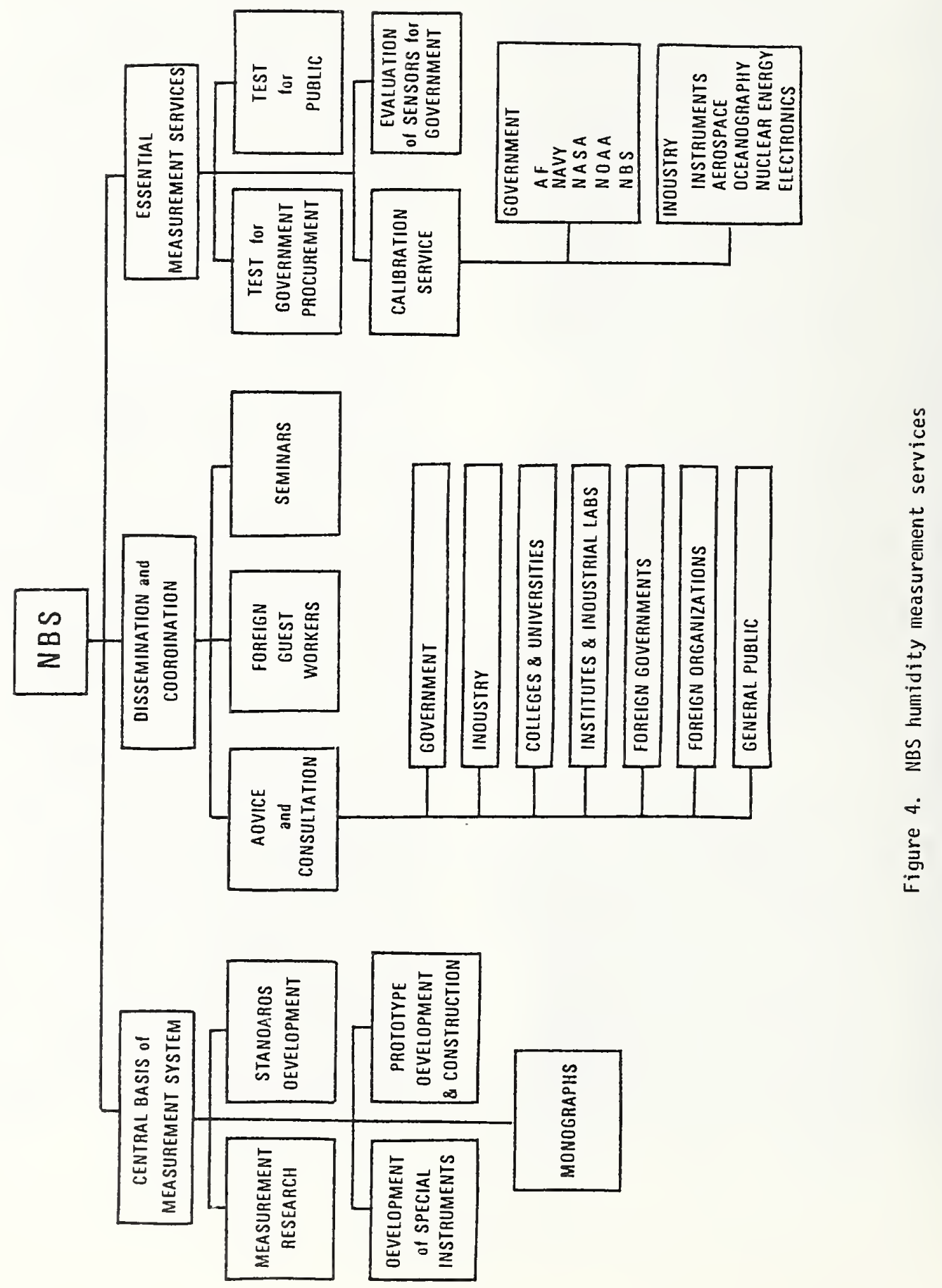


We turn now to the second NBS responsibility, the coordination and dissemination of capabilities in the Nional Measurement System. In the humidity sector, NBS discharges this by engaging in three activities:

(a) advice and consultation, (b) participation in seminars, and (c) hosting foreign guest workers.

Information, data, techniques, methods, procedures, references and reprints are disseminated by telephone, correspondence and visits. Those who have availed themseives of this assistance include Government agencies, industry, colleges and universities, research institutes, industrial laboratories, agencies of foreign governments, and foreign research and commerciai organizations. Many of these interfaces over the past decade are listed in Appendix $F$.

Tutorial lectures are given before professional societies, workshops, clinics and seminars. The following are a few of these organizations: (a) Moisture Measurement Ci inic, ISA, Rochester, $N$. J. 1971, (b) Symposium on Relative Humidity and Paper Test Methods, TAPPI, Grand Rapids, ilich., 1960, (c) 14th National Symposium, Analysis Instrumentation Division, ISA, Philadelphia, Pa., 1969, (d) Symposium on Weteorological observations and Instrumentations, AMS, Washington, D. C., 1969, and (e) Industrial Koisture

Measurement Course, Center for Professional

Development, Somervilie, N. J., Sept.

1973 and Feb. 1975.

Foreign guest workers are welcomed by NBS in its laboratories. The Humidity Section has hosted scientists from Japan and Romania.

The third NBS responsibility is to provide essential measurement services. These are available to the Government, industry and the pubic in support of the National Measurement System. NBS has the humidity measurements facilities shown in figure 5. A gravimetric hygrometer serves as the NBS primary reference standard [4]. This is a device which continuously and automatically withdraws a sample of moist gas from a constant humidity source, removes the water vapor in a train of $U$-tubes filled with desiccant, and then determines the volume of the effiuent dry gas by alternately filling and evacuating calibrated cylinders. The gain in weight of the absorption tubes and the measured volume of gas (converted to mass through pressure, temperature and density) give a measurement of humidity in units of mass of water vapor per unit mass of dry gas. Two precision generators are the main IIBS facilities for performing calibrations $[12,13,18]$. Cnly when the highest order of accuracy is required is the gravimetric hygrometer used for calibration of secondary standards. The NBS two-pressure humidity generator produces atmospheres of known humidity by saturating a gas stream at an elevated pressure and fixed temperature and expanding it to a lower (usually ambient atmospheric) pressure. The humidity is calculated from the pressures and temperatures, or, more preciseiy, is established and maintained at any desired value by selecting and then controlling appropriate temperatures and pressures. The NBS low frost-point generator operates on the two-temperature principle, that is, it produces an atmosphere of known humidity by saturating a gas stream at a selected temperature and fixed pressure and then heating the stream to a higher temperature at the same pressure. The frost point of the effivent gas stream is the same as the saturation temperature. Fixed points are obtained with selected saturated sait solutions whose equilibrium relative humidities have been established definitively by NBS. NBS humidity calibration ranges and accuracies are given in detail in table 18 .

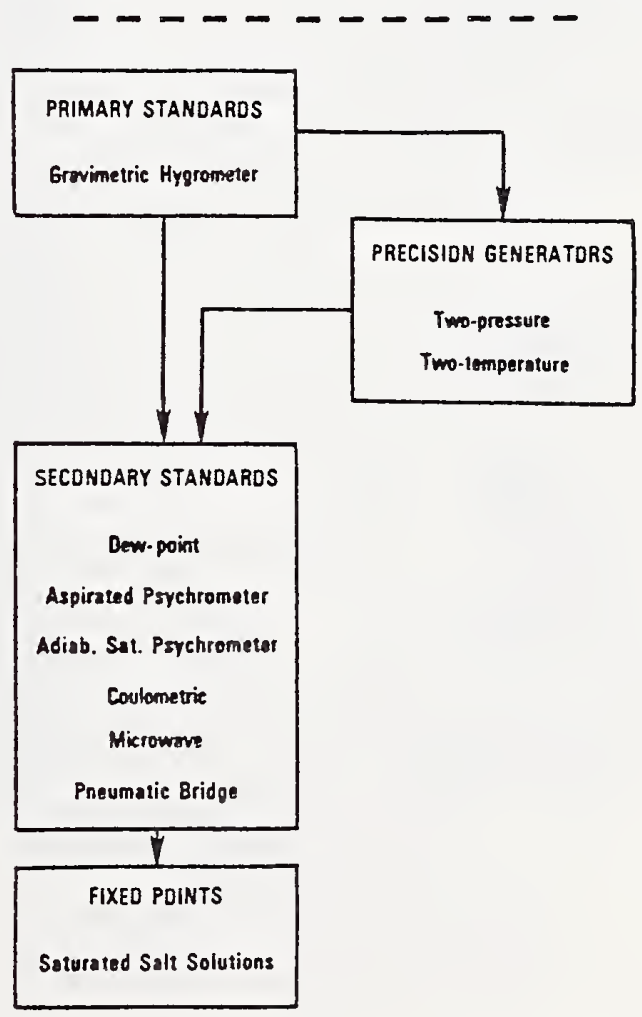

Figure 5. NBS humidity measurement capabilities 
Table 19. Types of instruments calibrated by NBS over the last ten years

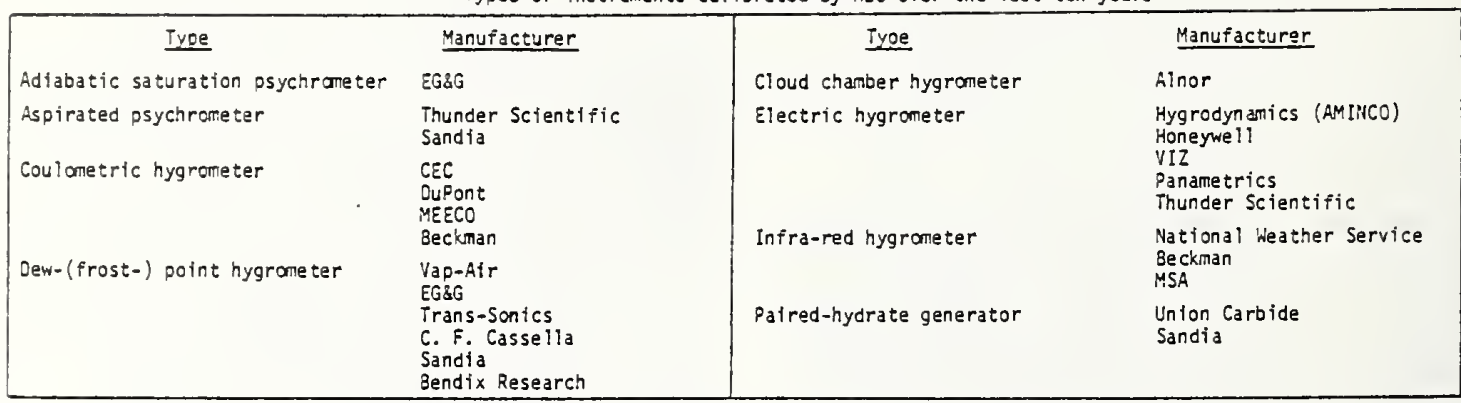

Table 20. Users of instruments calibrated by 185 over the last ten years

\begin{tabular}{|c|c|c|}
\hline \multicolumn{3}{|c|}{ Govermment } \\
\hline Agency & Immediate Purpose & End Use \\
\hline $\begin{array}{l}\text { NOAA, NWS } \\
\text { NBS, Oivision } 232.09 \\
\text { NBS, Oivision } 411.05 \\
\text { NBS, Oivision } 421.03 \\
\text { AF, Aerospace Res. Labs. (W-P AFB) } \\
\text { AFCRL } \\
\text { AF, Ha. Electronic Systems Oiv. } \\
\text { Amy, Frankford Arsenal } \\
\text { ilavai Eastern Standards Laboratory } \\
\text { U. S. Naval Electronics Lab (San Diego) } \\
\text { Nava i Research Laboratory } \\
\text { Interior (Bonnevtlle Power Admin.) } \\
\text { USAEC (Fort Monmouth) } \\
\text { USAEC (Fort Monmouth) } \\
\text { NASA, Kennedy Space Center } \\
\text { NASA, Langley Res. Center } \\
\text { NASA, Manned Spacecraft Center (Houston) } \\
\text { NASA, Marshall Space Flignt Center } \\
\text { NASA, (White Sands) }\end{array}$ & $\begin{array}{l}\text { Lab standard } \\
\text { Lab measurements } \\
\text { Transfer standard } \\
\text { Working instrument } \\
\text { Lab standard } \\
\text { Lab standard } \\
\text { Aircraft Measurements } \\
\text { Lab standard } \\
\text { Lab standard } \\
\text { Lab standard } \\
\text { Field measurements } \\
\text { Lab standard } \\
\text { Transfer standard } \\
\text { Helicopter measurements } \\
\text { Lab standard } \\
\text { Lab standard } \\
\text { Lab standard } \\
\text { Lab standard } \\
\text { Lab standard }\end{array}$ & $\begin{array}{l}\text { Meteorology } \\
\text { Mass calibrations } \\
\text { Interlaboratory tests } \\
\text { Thermal engineering tests } \\
\text { AF operation } \\
\text { Aerology } \\
\text { Air weather research } \\
\text { Ordnance } \\
\text { Nava! operation } \\
\text { Nava! operation } \\
\text { Laser propagation } \\
\text { Electric power } \\
\text { Atmospheric research } \\
\text { Air density } \\
\text { Aerospace } \\
\text { Aerospace } \\
\text { Aerospace } \\
\text { Aerospace } \\
\text { Aerospace }\end{array}$ \\
\hline \multicolumn{3}{|c|}{ Industry } \\
\hline Company & Immed late Purpose & End Use \\
\hline $\begin{array}{l}\text { Alnor } \\
\text { Aro } \\
\text { Bendix (Kansas City) } \\
\text { Bendix (Scintella) } \\
\text { Bendix (Sldney) } \\
\text { Boeing Company } \\
\text { Curtiss-Wright } \\
\text { EGaG } \\
\text { GE (Picayune) } \\
\text { General Oynamics - Convair } \\
\text { Gruman Alrcraft } \\
\text { Hamilton Standard } \\
\text { Hewlett-Packard } \\
\text { Hygrodynamics } \\
\text { Lockheed } \\
\text { LTV Electosystems } \\
\text { Martin (Oenver) } \\
\text { Monmouth Electric } \\
\text { North American Rockiwell } \\
\text { Sandia } \\
\text { Thunder Scientific } \\
\text { Tobacco Institute Testing Laboratory } \\
\text { Trans-Sonics } \\
\text { Union Carbide (Oak Ridge) } \\
\text { Vap-Air }\end{array}$ & $\begin{array}{l}\text { Lab standard } \\
\text { Wind tunnel standard } \\
\text { Lab standard } \\
\text { Lab standard } \\
\text { Lab standard } \\
\text { Lab standard } \\
\text { Lab standard } \\
\text { Lab standard } \\
\text { Lab standard } \\
\text { Lab standard } \\
\text { Lab standard } \\
\text { Lab standard } \\
\text { Lab standard } \\
\text { Lab standard } \\
\text { Lab standard } \\
\text { Lab standard } \\
\text { Lab standard } \\
\text { Lab standard } \\
\text { Lab standard } \\
\text { Lab standard } \\
\text { Lab standard } \\
\text { Lab standard } \\
\text { Lab standard } \\
\text { Lab standard } \\
\text { Lab standard }\end{array}$ & $\begin{array}{l}\text { Hygrometer manufactur ing } \\
\text { Air weather research } \\
\text { Atomic energy } \\
\text { Aerospace } \\
\text { Nuclear energy } \\
\text { Aerospace } \\
\text { Aerospace } \\
\text { Hygrameter manufacturing } \\
\text { Oceanography, aerospace } \\
\text { Aerospace } \\
\text { Aerospace } \\
\text { Aerospace } \\
\text { Electronics } \\
\text { Hygrometer manufacturing } \\
\text { Aerospace } \\
\text { Aerospace } \\
\text { Aerospace } \\
\text { Hygrometer manufacturing } \\
\text { Aerospace } \\
\text { Nuclear energy } \\
\text { Nuclear energy; aerology } \\
\text { Tobacco testing } \\
\text { Submarines; hygrometer mfg. } \\
\text { Nuclear energy } \\
\text { Hygrometer manufacturing }\end{array}$ \\
\hline
\end{tabular}


Concurrent with supplying measurement services, NBS has also been a user of the humidity and moisture measurement system in discharging its responsibilities and in perfoming its scientific and technological work. This activity has covered a wide range of investigations such as studying the effect of humidity on resistance of standard electrical resistors [135], paper [136-138], fibers and textiles [139-142], plastics [143146], collagen, hide and leather [147. 151], microchemical balances [152], engines [153], asphalt [154], air conditioning [155], ionization measurements [156], and floor coverings [157]. It has included studying the effect of moisture on various materials [158-164], and investigating water vapor turbulence [165], water vapor boundary layers [166-167], and evaporation [168].

The work involving the application of measurement technology to the solution of specific problems has been performed by a number of organizational units within WBS. The development, maintenance and dissemination of standards and the provision of a calibration service, on the other hand, is under the cognizance of the Humidity Section in the Institute of Basic Standards.

\subsection{The Present - Scope of NBS Services}

\subsubsection{Description of NBS Services.}

The primary responsibilities of INBS are to provide the central basis for the National Measurement System, to disseminate measurement capabilities to that system nationally and coordinate it with those of other nations, and to furnish essential services leading to accurate and uniform measurements throughout the USA. These responsibilities in the humidity sector are discharged for NBS by the Humidity section. How this is done is depicted in figure 4.

Consider, first, the NBS responsibility to provide the central basis for the humidity sector of the National Measurement System. This is accomplished primarily through work in five areas: (a) measurement research, (b) standards development, (c) development of special instruments, (d) prototype development and construction of secondary standards, and (e) publication of monographs.

Measurement research involves investigations of the properties, constants and behavior of water vapor and water vapor-gas systems and the development and improvement of methods of measurement. Examples include the experimental determination of the enhancement of water vapor in air [169], the determination of the cross-virial coefficients for moist air [170], the measurement of the vapor pressure of water at the triple point [171], and the development of formulations for the vapor pressure of water [172].

The development of new and improved standards is a continuing process that is designed to meet or anticipate the measurement calibration requirements of commerce, industry, science and technology. For example, there has been completed recently a new precision humidity generator for use in calibrating secondary and transfer standards. This will replace an apparatus that has been in constant use for over twenty years $[12,13]$. Earlier, a low frost-point generator was constructed capable of generating trace quantities of water vapor down to the parts per billion range [18]. The latter apparatus was built to meet a need of the Viking-Mars lander orogram for a facility capable of calibrating sensors under simulated Martian atmospheric conditions. A small humidity generator also was designed and fabricated for NASA for use on life support system studies [173].

The development of instruments for special applications is normally undertaken at the request of other government agencies and is usually intended to meet their mission-oriented needs. Typical of this type of work are a series of microwave hygrometers designed for use on a joint Navy-Forest Service warm air fog research project [49], a heated-air adiabatic saturation psychrometer for Air Force meteorological use [108], and a fastresponding humidity sensor for upper air sounding, cloud physics research and vapor flux measurements [109-111].

Prototype instruments are developed to meet the need's for secondary and transfer standards. Such instruments must have accuracy, repeatability and reliability and, preferably, should produce indications that can be predicted by the laws of physics. Two examples of such instruments are a preumatic bridge hygrometer [32] and an adiabatic saturation psychrometer [36].

Publications are issued which provide users of the measurement system with information on instruments, methods of measurement, sources of errors, and NBS capabilities $[55,93,174-176]$. 
Table 18. iBS humidity calibration ranges and accuracies

\begin{tabular}{|c|c|c|c|c|}
\hline Standard & $\begin{array}{l}\text { Amblent Corditions } \\
\text { of Test Gas }\end{array}$ & Unit & Range & Accuracy ${ }^{a}$ \\
\hline Gravimetric & 5 tandard atm. press. & $\begin{array}{l}\text { Hixing ratio, } \mathrm{r} \text {, } \\
\text { g water vapor } / \mathrm{kg} \\
\text { dry air }\end{array}$ & 0.19 to 20 & 0.13 percent of value \\
\hline \multirow{5}{*}{$\begin{array}{l}\text { Two-pressure } \\
\text { Huntdity } \\
\text { Generator }\end{array}$} & Standard atm. press. & $\begin{array}{l}\text { Mtxing ratio, } \mathrm{r} \text {, } \\
\text { g water vapor } / \mathrm{kg} \\
\text { dry air }\end{array}$ & $\begin{array}{l}0.002 \geq r<0.007 \\
0.007 \geq r<0.15 \\
0.15 \div r<20\end{array}$ & $\begin{array}{l}10 \text { percent of value } \\
3 \text { percent of value } \\
0.5 \text { percent of value }\end{array}$ \\
\hline & 5 tandard atm. press. & $\begin{array}{l}\text { Dew/frost point, } \\
T_{d},{ }^{\circ} \mathrm{C}\end{array}$ & $\begin{array}{l}-70=T_{d}<-65 \\
-65 \div T_{d}<-55 \\
-55 \div T_{d}<-45 \\
-45 \div T_{d}<-30 \\
-30<T_{d}<+25\end{array}$ & $\begin{array}{l}1.2 \\
0.8 \\
0.5 \\
0.2 \\
0.1\end{array}$ \\
\hline & 5tandard atm. press. & $\begin{array}{l}\text { Volume ratio, } V \text {, } \\
\text { ppm }\end{array}$ & 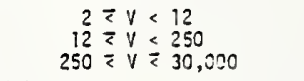 & $\begin{array}{l}\text { I0 percent of value } \\
3 \text { percent of value } \\
0.5 \text { percent of va!ue }\end{array}$ \\
\hline & $\begin{array}{l}\text { Test chamber (gas) } \\
\text { temperature, }{ }^{\top} c \text {, } \mathrm{C}\end{array}$ & $\begin{array}{l}\text { Relative humidtty, } \\
\text { percent }\end{array}$ & & \\
\hline & $\begin{array}{l}-55 \geqslant T<<-40 \\
-40<T_{C}^{c}<-30 \\
-30<T_{C} \geqslant+60 \\
\end{array}$ & & $\begin{array}{l}10 \text { to } 98 \\
10 \text { to } 98 \\
10 \text { to } 98 \\
\end{array}$ & $\begin{array}{l}2.5 \\
1.0 \\
0.5 \\
\end{array}$ \\
\hline \multirow{6}{*}{$\begin{array}{l}\text { Low } \\
\text { Frost-point } \\
\text { Generator }\end{array}$} & Standard atm. press. & $\begin{array}{l}\text { Mixing ratio, } r \text {, } \\
\text { g water vapor } / \mathrm{kg} \\
\text { dry atr }\end{array}$ & $\begin{array}{l}0.86 \times 10-5 \bar{z} r<0.16 \times 10^{-2} \\
0.16 \times 10^{-2}<r<0.024 \\
0.024 \quad \overline{<} r<0.233 \\
\end{array}$ & $\begin{array}{l}<7.4 \text { percent of value } \\
3.9 \text { percent of value } \\
<2.2 \text { percent of value }\end{array}$ \\
\hline & $500 \mathrm{~Pa}(5 \mathrm{mb})$ & $\begin{array}{l}\text { Mixing ratio, } r \text {, } \\
g \text { water vapor } / \mathrm{kg} \\
\text { dry air }\end{array}$ & $\begin{array}{ll}0.0017 & \sum r<0.33 \\
0.33 & <r<5 \\
5 & <r<51 \\
\end{array}$ & $\begin{array}{l}<1.6 \text { percent of value } \\
<1.0 \text { percent of value } \\
<0.8 \text { percent of va lue } \\
\end{array}$ \\
\hline & Standard atm. press. & $\begin{array}{l}\text { Frost point } \\
T_{d} \cdot{ }^{\circ} \mathrm{C}\end{array}$ & -100 to -30 & 0.05 \\
\hline & 5tandard atm. press. & $\begin{array}{l}\text { Voiume ratio, } \\
V \text {, ppm }\end{array}$ & $\begin{array}{l}0.014 \geq V<2.6 \\
2.6 \geq V<39 \\
39 \geq V<375\end{array}$ & $\begin{array}{l}<7.4 \text { percent of value } \\
<3.9 \text { percent of value } \\
<2.2 \text { percent of value }\end{array}$ \\
\hline & $500 \mathrm{~Pa}(5 \mathrm{mb})$ & $\begin{array}{l}\text { Volume ratio, } \\
\text { V, pprm }\end{array}$ & $\begin{array}{l}2.8 \geq V<500 \\
500 \geq V<8000 \\
8000 \div V=82,000\end{array}$ & $\begin{array}{l}<1.6 \text { percent of value } \\
<1.0 \text { percent of value } \\
<0.8 \text { percent of value }\end{array}$ \\
\hline & $\begin{array}{l}\text { Test chamber (gas) } \\
\text { temperature. T }{ }^{\circ} \text {, } \\
{ }^{\circ} \mathrm{C} \\
25 \\
0 \\
-25 \\
-50 \\
-75\end{array}$ & $\begin{array}{l}\text { Relative humidity, } \\
\text { percent }\end{array}$ & $\begin{array}{ll}0.44 \times 10^{-4} & \text { to } 1.2 \\
0.23 \times 10^{-3} & \text { to } 6.2 \\
0.22 \times 10^{-2} & \text { to } 60 \\
0.036 \times & \text { to } 53 \\
1.15 & \text { to } 45\end{array}$ & $\begin{array}{lrl}0.5 \times 10^{-5} \text { to } & 0.05 \\
0.3 \times 10^{-4} \text { to } & 0.32 \\
2.9 \times 10^{-3} \text { to } 3.6 \\
0.005 & \text { to } 4.0 \\
0.14 & \text { to } 4.3\end{array}$ \\
\hline \multirow{4}{*}{$\begin{array}{l}\text { Fixed Points: } \\
\text { 5elected } \\
\text { 5aturated } \\
\text { 5alt } \\
\text { Solutions }\end{array}$} & $\begin{array}{l}\text { 5tandard atm. press. } \\
\text { and at test chamber } \\
\text { (gas) temperature } \\
T^{\circ}{ }^{\circ}{ }^{\circ} \mathrm{C} \\
50 \\
50\end{array}$ & $\begin{array}{l}\text { Mixing ratio, } r \text {, } \\
\text { g water vapor } / \mathrm{kg} \\
\text { dry air }\end{array}$ & $\begin{array}{l}0.55 \text { to } 3.76 \\
8.8 \text { to } 82.7 \\
\end{array}$ & $\begin{array}{l}<1.9 \text { percent of value } \\
<1.4 \text { percent of value } \\
\end{array}$ \\
\hline & $\begin{array}{l}\text { Test chamber (gas) } \\
\text { temperature, } T^{c}{ }^{\circ} \mathrm{C} \\
0 \\
50\end{array}$ & $\begin{array}{l}\text { Dew/frost point, } \\
T_{d}{ }^{\circ} \mathrm{C}\end{array}$ & $\begin{array}{l}-23.8 \text { to }-0.1 \\
12.5 \text { to } 49\end{array}$ & $\begin{array}{l}0.2 \\
0.2\end{array}$ \\
\hline & $\begin{array}{l}\text { Standard atm. press. } \\
\text { and at test cnamber } \\
\text { (gas) temperature, } \\
{ }^{\top}{ }^{\circ}{ }^{\circ} \mathrm{C} \\
0 \\
50\end{array}$ & $\begin{array}{l}\text { Voiume ratio, } \\
\text { V, pprn }\end{array}$ & $\begin{array}{c}900 \text { to } 6,000 \\
14,000 \text { to } 133,000\end{array}$ & $\begin{array}{l}<1.9 \text { percent of value } \\
<1.4 \text { percent of value }\end{array}$ \\
\hline & $\begin{array}{l}\text { Test chamber (gas) } \\
\text { temperature, 'TC' } \\
{ }^{\circ} \mathrm{C} \\
0 \\
50\end{array}$ & $\begin{array}{l}\text { Relative humidity, } \\
\text { percent }\end{array}$ & $\begin{array}{l}15 \text { to } 99 \\
11 \text { to } 96\end{array}$ & $<1.9$ \\
\hline
\end{tabular}

a The accuracy (maximum uncertainty) includes the estimated systematic errors plus three standard deviations for the random errors. 
It should be noted that not all users of the humidity measurement system show direct traceability to the ilBS primary humidity standard. Some users establish their own absolute methods of measurement, use their own humidity generators, or set up their own fixed points. Others rely on a secondary standard wi thout IVBS calibration. Some of the reasons for this may be an ignorance of IIBS services or the cost of NBS calibrations. It is difficult to estimate the percentage of the system users who go their own way wi thout tying directly or indirectly with NBS.

The NBS measurement services that are available may be divided into four categories: (a) calibration of plant and laboratory standards, (b) evaluation and testing of sensors for special government programs, (c) test for compliance with government procurement specifications, and (d) tests for the public.

\subsubsection{Users of NBS Services.}

Instruments that are submitted for calibration as plant or laboratory standards include the following: psychrometers, dew-point hygrometers, electric hygrometers, coulometric hygrometers, infra-red hygrometers, pneumatic bridges, paired-hydrate generators. Table 19 is a list for the last ten years of secondary standards calibrated by NBS and the manufacturers of these instruments. The principal users of these instruments are government and industry. The immediate use of these instruments, for the most part, is as laboratory standards. The end purposes are varied, with aerospace, instrument manufacturing and meteorology predominating. A detailed breakdown of users of instruments calibrated by ils over the last ten years is given in table 20 .

\subsubsection{A7ternative Sources}

The availability of humidity calibration and testing services from other sources has been mentioned in section 2.4.3. Few, if any, of these organizations have the necessary facilities for performing calibrations at the highest level accuracy. Within the Federal Government there is equipment at the U. S. Army Electronic Command (Fort lionmouth, N. J.) that could be used for calibration purposes. Several of the instrument manufacturers wi 11 perform calibrations for customers. The Standards Laboratory of the Sandia Corporation (Albuquerque, M. M.) provides services to the atomic energy community.

Calibration services for moisture meters may be obtained from commercial testing laboratories. The USDA has facilities and the capabilities for providing calibrations of moisture meters for grain and other agricultural commodities. Several of the States, through their veights and measures offices, can produce calibrations although the States usually Timit their operations to enforcing compliance of instruments with State laws and regulations.

liost we 11-equipped chemical laboratories usually have the competence to perform routine moisture measurements on a variety of materials using oven drying methods, Karl Fischer titrations and azeotropic distillation procedures.

\subsubsection{Funding Sources for NBS Services.}

The establishment and maintenance of national standards, the supporting research and the determination of evaluated data are functions that NBS supports through funds obtained by direct appropriation from Congress. The calibration and testing services, whether to Government agencies or to the public, are performed on a reimbursable basis. Other measurement activities for Government agencies are funded by those agencies requesting the work.

\subsubsection{Mechanisms for Supplying Services.}

Calibration and testing services are provided to a customer through the submission by the latter of an acceptable instrument. After the completion of the work the instrument, together with a report of calibration, is returned to the customer. NBS sets no requirements for the frequency of calibration.

\subsection{Impact of NBS Services}

It is difficult to establish the direct and immediate economic impact of NBS services on industry, commerce and Government. It is even more difficult to assess the indirect ?everage that may be exerted on the final users of the humidity and moisture measurement system. Perhaps a quantitative picture of this economic structure will eventually evolve as more data are accumulated. 
The first-line users of NBS calibration services have been identified in table 20. It is safe to assume that these services support Government activities and industrial and technological operations of sizeable economic proportions. It is also safe to assume that. IBS has contributed significantly to the measurement system by providing advice, consultation, and information to Government, industry, colleges, universities, institutes, industrial laboratories, and foreign agencies and organizations (see Appendix F).

One instrument manufacturer has stated:

"There is no question in my mind that NBS has played a very significant role in the development of the humidity instrumentation business. Your facility is the only one where a fult-range, unbiased evaluation of a particular humidity measuring sensor or system can be conducted.

The typical \$l-milition-sales manufacturer cannot justify the expense of operating a two-pressure generator or similar calibration facility. When one considers that nearly 50 percent of a 11 humidity instruments are sold to the U.S. Government (either directly, or indirectiy through contracts), much of the industry thusly looks to Government users for comments on performance (or, more specificaliy, to substantiate manufacturer's claims--al though I realize that this is not the desired role of NBS), the actual role of INSS is clearly seen. For example, if it were not for the NBS facilities during the space effort of the mid60's, MASA Taboratories all over the country would have had to develop extensive and expensive facilities to verify the performance of humidity sensors employed in the critical life support systems on the Apollo program. A similar case can be made for humidity sensors applied on the Poseidon program, where every submarine has between 32 and 64 optical hygrometers which carry laboratory certifications made against an iNBS-calibrated reference instrument. I am sure many manufacturers can trace 'NBS-verification arguments' for the selection of their sensor in a particular application."
NBS calibrations of a commercial "dewcel"humidity probe for the National Weather Service (iWS) contributed to the accuracy of the observations that are and witl be used for weather predictions. NWS has an annual installation and replacement rate of 100 of these units at a cost of $\$ 400$ each. In addition, units will be installed at 500 airports at $\$ 500$ each.

Another case that may be cited is the procurement by DOD and NWS of carbon sensors, at a cost of about $\$ 2$ per unit, for use in radiosonde flights. Approximately 150,000 sensors are flown annually. Prototype samples are submitted to NBS by these Government agencies for calibration and lag tests when the accuracy of the manufacturer's test facility is in question or a new company needs to be qualified. The Mars Viking Mission included a vehicle which witl land on the surface of Mars and seek evidence of 1 ife. Because humidity is one indicator of life as we know it, early plans envisioned measuring the humidity of the Martian atmosphere. This atmosphere is essentially $\mathrm{CO}_{2}$ at a pressure of about 500 pascals and at ambient temperatures as low as $-100^{\circ} \mathrm{C}$. NASA requested the ass istance of NBS in establishing traceable standards for calibrating the humidity sensor to be used for this measurement. NBS designed and built a humidity generator capable of producing frost points as low as $-100^{\circ} \mathrm{C}$ in a simulated Martian a tmosphere. Because of funding constraints, NASA deleted the humidity experiment from the Viking lission. NBS retained the generator and subsequently used it to study and evaluate sensors for stratospheric humidity measurements for COT's Climatic Impact Assessment Program and for NASA tropopause and stratospheric meteorological investigations.

\subsubsection{Economic Impact of Major User Classes.}

See Section 3.1.2.

\subsubsection{Technological Impact of Service.}

See Section 3.1.1.

\subsubsection{Payoff From Changes in NBS Services.}

See Section 4.3 . 


\subsection{Evaluation of NBS Program}

The NBS humidity measurements program has been reviewed annually by the Evaluation Panel of the National Academy of Sciences (NAS) for the Mechanics Division. This Panel periodically has commented favorably on the quality and content of the humidity measurements program. However, the Panel has noted that work in humidity measurements was somewhat outside of the specific expertise of its past membership. Therefore, it did not assess critically the scientific content of the program. In 1974, NAS appointed to the Panel for the first time a member with technical expertise in the humidity measurements area. We can expect that the strengths and weaknesses of the program will be evaluated in greater depth and that helpful recommendations wi 11 be forthcoming.

Although NBS currently has adequate facilities and resources to meet most of the measurement system user needs, there still are some shortcomings. NBS can furnish calibrations, through its generators, over a wide range of humidities (from ppb to 15 percent) and over ambient temperatures from to to $-100^{\circ} \mathrm{C}$. Over most of this humidity range the ambient pressure is restricted at present to atmospheric pressure; over a restricted humidity range (ppb to 0.2 percent) ambient pressures as low as $500 \mathrm{~Pa}(5 \mathrm{mb})$ can be achieved. A new facility, which will soon become operational, will extend the upper (high) end of the humidity range to about 70 or 80 percent water vapor content, allow ambient temperatures as high as $90^{\circ} \mathrm{C}$ and ambient pressures as high as $2 \times 10^{5} \mathrm{~Pa}$ (2 bars) and as low as 25,000 Pa (1/4 bar). Even after placing the new facility into use there will still be some deficiencies. There will be no capability for performing calibrations at high temperatures (above $100^{\circ} \mathrm{C}$ ), such as encountered in drying operations in lumber kilns. Nor will there be any capability for calibrating at pressures in excess of $2 \times 10^{5} \mathrm{~Pa}$ ( 2 bars), such as encountered in high pressure gas operations and process lines. In the ppm and ppb regions our procedures and techniques are constrained by practical difficulties: low flow rates in the generator, long equilibration times and high cost of operation.

The gravimetric hygrometer which serves as the MBS primary standard is 1 imited in its capability of measuring very low humidities (in the ppm and pob reqions) and at high humidities (where condensation can occur). It is likely that another absolute method will have to be developed to cover these regions.

The NBS facilities are deficient in their capacity to perform response time studies on humidity sensors. In providing calibration and testing services the need often arises for measuring the lag of a sensor. This can now be done only partially. What is required is an apparatus designed specifically to produce discrete and rapid changes in humidity and having the capability for adjusting such parameters as the magnitudes and direction of the humidity change, the temperature, and the total pressure.

\subsection{The Future}

There unquestionably will be a need in the foreseeable future for NBS to continue to develop, improve, maintain and promulgate standards and calibration procedures for humidity measurement. The new precision (two-pressure) humidity generator that will soon become operational should be capable of meeting the anticipated calibration work loads for many years. Plans have been drafted for coupling this generator to a minicomputer, thus providing automatic operation as well as automatic acquisition and processing of data. The schedule for this latter phase of the work is contingent on funding and delivery dates. However, it is reasonable to anticipate completion by 1976. NBS will continue to provide critically evaluated data on the pure water substance and on water vapor-gas systems.

In nart as a result of this National Measurement System study, we have identified serious deficiencies in the measurement system for moisture, and have initiated a program to resolve these. The objectives of the work are (1) the development and promulgation of standards and calibration procedures directly traceable to NBS;

(2) the evaluation, improvement and development of methods and instruments for moisture measurement; and (3) the development of new principles of moisture measurement, promulgation of evaluated data, and investigation of phenomena and behavior of moisture in materials. The initial effort will be directed toward solving several pressing problems related to grain, particularly to the grain moisture meter problem of the state weights and measures community. Subsequently, moisture measurement problems in other materials will be addressed. 


\section{SUMWARY AND CONCLUSIONS}

Humidity and moisture are quantities which affect science, industry, commerce and trade. Their measurement and control are vital to our socio-economic system. A broad spectrum of instrumentation, from simple inexpensive devices to complex, sophisticated, costly apparatus, is available. NBS maintains and disseminates standards for humidity, exerts a leadership role in advancing the state of the art, and interacts with the technical community to support the need of users for measurement services.

There are no national standards in moisture measurement directly traceable to NBS. Although there is a documentary specification system that includes several different methods of moisture measurement as reference standards, there is no general agreement on which one to use. Because of the economic impact that errors in measurement have on equity in trade, conservation of fuel and energy, and preservation of food and materials, it is essential that NBS assume the responsibility for establishing standards and improving the moisture measurement system.

The humidity and moisture sector of the National Heasurement System supports large and critical segments of our industry, technology, agriculture and commerce. It is essential that this system remain strong and healthy in order to effectively meet the continuing and growing measurement needs of the country.

\section{APPENDIX A. METHODOLOGY OF THE STUDY}

The design of this study is given by the outline of the contents. Basically, five tasks were undertaken: (a) to describe the humidity and moisture components of the National Measurement System; (b) to determine the current status of these components; (c) to analyze the major societal impacts of these parts of the system; (d) to identify important trends; and (e) to examine how NBS interacts with the system.

Information and data were sought and obtained from a variety of sources. A major source was the expert knowledge of the state of the art of the technical staff of the Humidity Section. This was augmented by data abstracted from correspondence, calibration reports, internal memoranda, visitor log books and other documents in Section files. The catalogs and technical literature of instrument manufacturers were searched.

A compilation was made of manufacturers who produce and sell humidity and moisture instruments using internal catalog files, and lists published in trade and technical journals, and books. One hundred and ninety manufacturers were then surveyed for economic and marketing information. Of these, 59 replied, 22 supplied sales data and 19 supplied other marketing information. These data were then augumented by a 1 imited number of Oun and Bradstreet reports, Social and Economic Administration Reports on Selected Instruments and Related Products, and data from the U. S. Industrial Outlook for 1974 issued by the Domestic and International Business Administration. Selected agricultural data were obtained from Agricultural Statistics 1974 issued by the U. S. Department of Agriculture.

The Section maintains in its files a comprehensive bibliography and an extensive collection of papers, reports, publications, reprints, patents and documents on the humidity and moisture. This collection was searched to obtain pertinent data on significant elements of the measurement infrastructure and for information on other aspects of this study.

A workshop on moisture in grain, and one on the application of nuclear magnetic resonance to moisture measurement were held under NBS sponsorship. These provided usefut inputs from representatives from trade associations, State weights and measures officials, industry and Government on the status and problems of the moisture measurement technology.

Numerous contacts in person and by telephone and correspondence, both prior to and during this study, were made with calibration clientele, Government agency sponsors of humidity work at NBS and instrument manufacturers. Over a period of many years, section personnel have provided advice, consultation, and information to government, industry, colleges and universities, institutes, industrial laboratories, agencies and other organizations of foreign countries. These contacts have contributed to the store of wisdom in the staff which was tapped for this study.

Due to the constraints of time, manpower and funding, the data base for this study is heavily weighted with material from accessible sources: staff wisdom, Section files, technical and scientific literature. Trends and forecasts represent educated view-points of NBS staff members and are not the result of a Delphi or more in-depth study. 


\section{APFENDIX B. SUMMARY OF BACKGROUNO DOCUMENTS}

1. Correspondence Files of Humidity Section. These files contain letters to and from Government agencies, industry, colleges and universities, institutes, industrial laboratories, agencies of foraign goverrments and foreign research and comercial organizations requesting information, data, techniques, methods, procedures, references and reprints on the measurement sys tem.

2. Caibration Reports. In addition to calibration data, these reports contain the names of the manufacturers of the instruments submitted, data on the operating principies of the instruments tested, and the names of the users of the calibrated instruments.

3. Visitors' Register. The name, affiliation and purpose of eacn visitor is recorded.

4. Catalogs of instrument Manufacturers. The section maintains a file of catalogs and other manufacturer's literature on humidity and moisture instrumentation. These were used as a source on the Instrumentation System.

5. Thomas Register. This publication contains an extensive classified iist of manufacturers, their products, and the magnitude of their tangible assets.

6. ISA Transducer Compendium. The chaoter on humidity lists manufacturers of numidity sensors, together with descriptions of the performance characteristics of the devices.

7. Survey of Instruments for lificrometeorology by J. L. Monteith, Blaskiwell Scientific Publications, Oxford, 1972 . This is a guide to the choice of comercial irstrumentation. It includes specifications and costs on hygrometers and moisture meters.

8. Moisture and Humidity, a staff survey aopearing in Measurements and Data, Jar-feb 1973. This article lists commercia? instruments, operating ranges, and costs.

9. Guide to Scientific Instruments, Science 182A, 27 November 1973 . This is a classified listing of instrument manufacturers.

10. Buyers' Guide 1974, Instruments and Control Systems. This is a classified listing of instrument manufacturers.
11. Current Industrial Reports. Selected Instruments and Related Products 1971 . Series: MA-38B(71-1), March 1973, Bureau of the Census. This publication cortatins data on the ouantity and value of shipments of selected instruments and related products.

12. U. S. Industrial Outiook 1974, U. S. Dept. Comerce, Domestic and Internatioral Business Administration. Assessments are made of future trends for major inoustrial manufactured prociucts. Cata are given on values of shipments.

13. U. S. Grain Standards Act A.s Amended, August 15,1968 . This is the enabling iegisiation giving the USDA the legal authority for promuloating regulations and standards for grain crops entering interstate and foreign commerce.

14. Erain Standards, Formal and Informal Procedures, Rules and Regulations, Federal Register, Honday, July 8, 1974 , Vol. 39, ilo. 13i, Part II. Amendments to the U. S. Grain Standards Act.

15. Oven Methods for Moisture Determination, GR Hotice 1211, issued by USDA, Corsuner and Marketing Service, Grain Division, $11 / 15 / 71$. Official USDA methoc's for determining moisture ir. grain by oven drying methods.

16. USDA, AMS, Service and Regulatory Announcement ilo. 147, Revised March 1959, Method of Determining Moisture Content as Specified in the Official Grain Standerds of the United States and in the United States Standards for Beans, Peas, Lentils and Rice. This document specifies oven drying methods.

17. Agricuitural Statistics 1973, USDA, U. S. Government Printing Office, Washington. This oublication includes data of the annual oroduction, season average price received by farmer and annual farm value of agricuttural crops.

18. Dun and Bradstreet Reports. These reports inciude marketing information on a selectad number of instrument manufacturers.

19. Fartial List of Rapid Moisture-Testing Devices for Grain and Related Commocities, issued by the Grain Division, Consumer and Marketing Service, USDA, January 1967.

20. A Partial List of Hoisture Tester Users, C. W. Brabender Instrunents. This is a itst of companies, classified 
by industry and product, who use the Brabender oven drying tester for determining moisture content.

21. How to Grade Grain, issued by Burrows Equipment Co. This publication contains a condensed version of the procedures and specification for grading grain condensed from the Grain Grading Primer of the USDA.

22. Checks on Moisture Testers Urged, by Tom Patrick, Des Moines, Iowa Register, December 22, 1968. A newspaper story on wide range in readings obtained with different moisture meters testing the same samples of grain.

23. Moisture and Its Measurement by I. HTynka and A. D. Robinson in the Storage of Cereal Grains and Their Products ( $J$. A. Anderson and A. W. Alcock), American Association of Cereal Chemistry, St. Paul, 1954. This chapter deals with the interrelationships between moisture and grain and the methods used to measure moisture.

24. What Designers Should Know About Humidity by A. P. Harris and E. W. Parrott, Electronics, October 30, 1959. This article discusses problems which designers of ground and space electronic equipment face with regard to humidity and moisture.

25. ASHRAE Guide and Jata Book, American Society of Heating Refrigerating and Air Conditioning Engineers. This handbook contains chapters on humidification; sorption dehumidification and pressure drying equipment; process and product air conditioning; printing plants; textile processing; factory dehydrating, charging and testing; and moisture in refrigerant systems.

26. Handbook of Air Conditioning, Heating and Ventilating by Strock and Koral. Industrial Press, 1965. Data are given on the temperature and humidity conditions for industrial plants which manufacture or process a wide assortment of products. There are also included air conditioning design criteria for commercial buildings and transportation equipment.
27. Selected ASTII Standards:

(a) E41-63 (Reapproved 1971), Standard Definitions of Terms Relating to Conditioning. These terms pertain to the conditioning of materials for test purposes.

(b) $596-66$, Standard Methods of Test for Water Vapor Transmission of Materials

in Sheet Form. These methods cover determinations of the rate of water vapor of materials in sheet form. The methods are applicable to materials such as paper, plastic films, and sheet materials in general.

(c) E104-51 (Reapproved 1971), Recommended Practice for Maintaining Constant Relative Humidity by Means of Aqueous Solutions. The methods use aqueous glycerin solutions, aqueous sulfuric acid solutions and aqueous salt solutions.

(d) $8171-63$ (Reapproved 1972), Standard Specification for Standard Atmospheres for Conditioning and Testing llaterials. This standard lists three acceptable standard atmospheres of humidity and temperature. It also lists conditioning requirements for specific materials. (e) E392-69T, Tentative Recommended Practice for Equipment for Conditioned Atmospheres: Temperature and Relative Humidity. This recommended practice covers performance and construction requirements for equipment to be used in obtaining condicioning a tmospheres of temperature and humidity in a space volume of $0.14 \mathrm{~cm}^{3}\left(5 \mathrm{ft}^{3}\right)$.

(f) E398-70, Standard Recommended Practice for Dynamic Measurement of !later Vapor Transfer. This recommended practice covers dynamic evaluation of the rate of transfer of water vapor through a barrier material.

28. Moisture in Grain Workshop. Internal NBS document of Mechanics Division summarizing results of a meeting held on June 13, 1974, at NBS. Workshop was attended by respresentatives from Government, industry, trade associations and weights and measures officials. The workshop drafted specific recommendations regarding actions NBS should take concerning critical problems in measuring and providing standards for moisture in grain. 
APPENDIX C. MANUFACTURERS OF HUMIOITY INSTRLMENIS AND CDNTRDLS

\begin{tabular}{|c|c|c|}
\hline \multicolumn{3}{|c|}{ Dew Doint } \\
\hline $\begin{array}{l}\text { Chandler Engineering Company } \\
\text { Comoustion Engineering } \\
\text { Compudyne Corporation } \\
\text { East, Environmental Eq. Div. } \\
\text { Environnental Tectonics Corp., } \\
\text { Comercial Products Division } \\
\text { Foxboro }\end{array}$ & $\begin{array}{l}\text { General Eastern Corporation } \\
\text { Hankison Corporation } \\
\text { Heavy-Outy Heating Equipment Co. } \\
\text { Ipsen Industries, Inc. } \\
\text { Leone Engineering Company } \\
\text { Pananetrics }\end{array}$ & $\begin{array}{l}\text { Robbins Aviation, Inc. } \\
\text { Technology/Versatronics, inc. } \\
\text { Trans-Sonics, Inc. } \\
\text { Iri-Met Associates, Inc. } \\
\text { Vap-Air Oivision of Vapor } \\
\text { Corooration (Singer Co.) } \\
\text { Weighing and Controls, Inc. }\end{array}$ \\
\hline \multicolumn{3}{|c|}{ Color Change } \\
\hline $\begin{array}{l}\text { D. C. Coper Company } \\
\text { Henry Valve Company }\end{array}$ & $\begin{array}{l}\text { Humidial Company } \\
\text { Industrial Packaging } \\
\text { Products Company }\end{array}$ & $\begin{array}{l}\text { Jacoby-Tarbox, Inc. } \\
\text { Kainl Scientific Instrument } \\
\text { Corporation } \\
\text { Robbins Aviation, Inc. }\end{array}$ \\
\hline \multicolumn{3}{|c|}{ Electric } \\
\hline $\begin{array}{l}\text { Anerican Instrument Co. (Hygrodynamics) } \\
\text { Atlantic Instrwmert \& Electronics, Inc. } \\
\text { Sarber-Coleman Co., Industrial Instr. Div. } \\
\text { Beckman (Cesar Grove) } \\
\text { Gry-Air. Inc. } \\
\text { General Eas:ern Corporation }\end{array}$ & $\begin{array}{l}\text { Gulton Industries, Inc., } \\
\text { Rustrak Instrument Div. } \\
\text { Honeywell } \\
\text { Jelrus Technical Products Coro. } \\
\text { Lab-Line Instruments, Inc. } \\
\text { Panametrics } \\
\text { Phys-Chemical Res. Corp. }\end{array}$ & $\begin{array}{l}\text { Thunder Scientific Corporation } \\
\text { Veekay Limited } \\
\text { Victoreen Instrumert Co. } \\
\text { VIZ Manufacturing } \\
\text { Waynco Inc. } \\
\text { Cosa Corporation }\end{array}$ \\
\hline \multicolumn{3}{|c|}{ Mechanical } \\
\hline $\begin{array}{l}\text { Abbeon } \\
\text { Airguide Instrunent Company } \\
\text { inerican Moistening Co. } \\
\text { Anstro Corporation } \\
\text { Atikins Technical Company } \\
\text { Bacnarach Instrument Company } \\
\text { Bahnscn Company } \\
\text { Earser-Colenan Co., Industrial } \\
\text { instrumen:s Div. } \\
\text { Belfort instrument Company } \\
\text { Bendix Corporation, Environmental } \\
\text { Sclence Jivision } \\
\text { Bristol Div. of Arerican Chain and } \\
\text { Cable Company } \\
\text { Brcoklyn ihermometer Co. } \\
\text { Climatronics Corporation }\end{array}$ & $\begin{array}{l}\text { Climet Instruments, Inc. } \\
\text { D. C. Cooper Company } \\
\text { Edroy Products Co. Inc. } \\
\text { Environmental Tectonics Corp. } \\
\text { Comercial Products Div. } \\
\text { Epic, Inc. } \\
\text { Foxboro } \\
\text { Henry J. Green, Inc. } \\
\text { E. Vernon Hill, Inc. } \\
\text { Honeywel] } \\
\text { Impact Register, Inc. } \\
\text { Johnson Service Company } \\
\text { Kanl Scientific Instrument Corp. } \\
\text { Kent Cambridge Instrument Corp. } \\
\text { Luft Instruments, Inc. } \\
\text { Lux Scientific Instrument Corp. }\end{array}$ & $\begin{array}{l}\text { Meteorology Research Inc. } \\
\text { New Jersey Safety Eq. Cu. } \\
\text { Pacific Transducer Corp. } \\
\text { Philadelphic Scientific } \\
\text { Controls, Inc. } \\
\text { Phys-Chemical Res. Corp. } \\
\text { Powers Regulator Company } \\
\text { Science Associates Inc. } \\
\text { Scientific Systems Corforation } \\
\text { Taylor Instruments, Pro:ess } \\
\text { Control Div. Sybon Corporation } \\
\text { Testlab Div. of GDI, Inc. } \\
\text { Testing Machines, Inc. } \\
\text { Texas Electronics, Inc. } \\
\text { Watrous and Company. Inc. } \\
\text { Weatherneasure Corporation } \\
\text { Weksler Instrument Corporation }\end{array}$ \\
\hline \multicolumn{3}{|c|}{ Psychrometric } \\
\hline 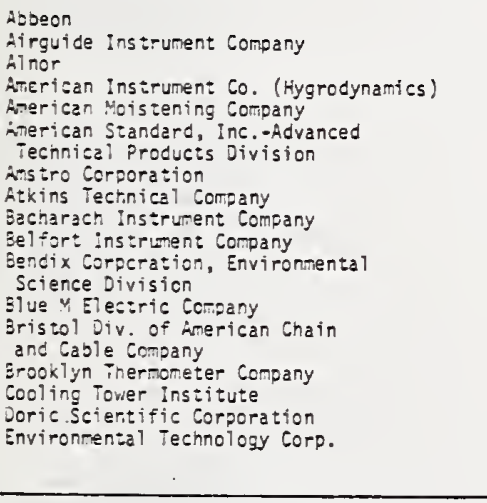 & $\begin{array}{l}\text { Environmentai Tectonics Corp., } \\
\text { Commercial Products Div. } \\
\text { Epic, Inc. } \\
\text { Esterline Angus Div., Esterline Corp. } \\
\text { Fischer and Porter } \\
\text { Foxboro } \\
\text { Gas Drying } \\
\text { Genera1 Eastern Corporation } \\
\text { G. M. Mfg. and Instrument Corp. } \\
\text { Henry J. Green, Inc. } \\
\text { Harrel, Inc. Taylor Instruments, } \\
\text { H-B Instrument Company, inc. } \\
\text { E. Vernon Hill. Inc. } \\
\text { Honeywell } \\
\text { Integrated Development and Mig. Co. } \\
\text { Kanl Scientific Instrument Corp. } \\
\text { Leeds and Northrop } \\
\text { Leone Engineering Company } \\
\text { Manning, Maxweli and Moore, Inc. } \\
\text { Marshalitown Mfg. Inc. } \\
\text { Mee Industries, inc. }\end{array}$ & $\begin{array}{l}\text { Moeller Instrument Company } \\
\text { Pacific Transducer Corforation } \\
\text { Partlow Corporation } \\
\text { Phys-Chemical Research Corp. } \\
\text { Precision Thermometer anc } \\
\text { Instrument Company } \\
\text { Princo Instruments, Inc. } \\
\text { Science Associates, Inc. } \\
\text { Scientific Systems Corp. } \\
\text { sigme Instruments Inc. } \\
\text { Taylor Instruments, Process } \\
\text { Control Div. , Sybron Corp. } \\
\text { Testing Machines, Inc. } \\
\text { Thunder Scientific Corporation } \\
\text { y. O. Irecice Company } \\
\text { U.E.C. Industries, Inc. } \\
\text { Weathermeasure Corporition } \\
\text { Weksler instrument Coro. } \\
\text { Westronics, Inc. (subsicary of } \\
\text { Tracor, Inc.) } \\
\text { Wilkerson Corporation } \\
\text { Yellow Sorings instrumeni. Co. }\end{array}$ \\
\hline \multicolumn{3}{|c|}{ Coviometris } \\
\hline $\begin{array}{l}\text { Anerican Standard, Inc. } \\
\text { Advanced iechnical Products Div. } \\
\text { seckran, Scientific and Process } \\
\text { Instruments Division } \\
\text { E. 1. Dupont de Hemours \& Co.. } \\
\text { instrurent Progusts Div. }\end{array}$ & $\begin{array}{l}\text { Genera } 1 \text { Eastern Corporation } \\
\text { Kann and Company, Inc. } \\
\text { 'lanufacturers' Eng. and Eq. Corp. }\end{array}$ & $\begin{array}{l}\text { Dlin Corooration } \\
\text { Process Analyzers, Inc. } \\
\text { Science Associates, Inc. }\end{array}$ \\
\hline \multicolumn{3}{|l|}{ Anstricent Prowets div. } \\
\hline
\end{tabular}


APPENOIX C (CONTINUED)

\begin{tabular}{|c|c|c|}
\hline \multicolumn{3}{|c|}{ Saturation Salt Solutions (Dewcels and Ceworobes) } \\
\hline $\begin{array}{l}\text { Atxins Technical Company } \\
\text { Bristol Oiv. of Anerican Chain } \\
\text { and Cable Company } \\
\text { Climatronics Corporation }\end{array}$ & $\begin{array}{l}\text { Oavis Instruments Mfg. Co., Inc. } \\
\text { Thomas A. Edison Industries } \\
\text { Foxboro } \\
\text { General Eastern Corporation }\end{array}$ & $\begin{array}{l}\text { Honeywell } \\
\text { Science Associates, inc. } \\
\text { Weathermeasure Corooration } \\
\text { Yellow Springs instrumient co. }\end{array}$ \\
\hline \multicolumn{3}{|c|}{ Cloud Chamber } \\
\hline \multicolumn{3}{|l|}{ Alnor Instrument Corporation } \\
\hline \multicolumn{3}{|c|}{ Spectroscooic (IR and UV) } \\
\hline Block Associates, Inc. & $\begin{array}{l}\text { E? ectromagnetic Research Corp. } \\
\text { (Lyman a) }\end{array}$ & Wtiks Scientific Corp. \\
\hline \multirow{2}{*}{\multicolumn{3}{|c|}{$\begin{array}{l}\text { E. I. Juoont de Vemours \& } \mathrm{Co}, \text {, } \\
\text { Instrument Products OIv. }\end{array}$}} \\
\hline & & \\
\hline \multicolumn{3}{|c|}{ Heat of Sorotion } \\
\hline Mine Safety Apolitances Company & & \\
\hline
\end{tabular}


APPEIUIX O. MANUFACTURERS OF MOISTURE METERS ANO COMTROLS

\begin{tabular}{|c|c|c|}
\hline \multicolumn{3}{|c|}{ Gravimetric } \\
\hline $\begin{array}{l}\text { Central Scientific Conoany } \\
\text { Harry 'A. Jietert Company } \\
\text { Dyratroric Instrument Corporazion } \\
\text { Greiner Scientific Corporation } \\
\text { Lab-Line Insirurents, Inc. } \\
\text { Onaus Scale Corporation } \\
\end{array}$ & $\begin{array}{l}\text { Brabender Corooration } \\
\text { C. K. Brabender Instruments, Inc. } \\
\text { Scientific Supoly Division } \\
\text { Kettronies, ine. } \\
\text { OAL Associates } \\
\text { Precision Scientific }\end{array}$ & 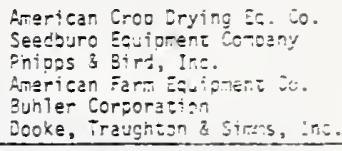 \\
\hline \multicolumn{3}{|c|}{ Neutron Back Scatter } \\
\hline $\begin{array}{l}\text { Kaiser Aerospace \& Electronics Corp. } \\
\text { Seaman iuciear Corporation }\end{array}$ & $\begin{array}{l}\text { Kay-Ray, Inc. } \\
\text { ieszlab Civision ef GDI, Ine. }\end{array}$ & Nuelear Chicazo iarporazion \\
\hline \multicolumn{3}{|c|}{ HMR } \\
\hline $\begin{array}{l}\text { E. I. DuFont de Vlemours \& } 60 . \\
\text { instrument Products Oiviston }\end{array}$ & Newport of Vortn America & The Praxis Corporazich \\
\hline \multicolumn{3}{|c|}{ Karl Fischer } \\
\hline $\begin{array}{l}\text { Greiner Scientific Corporation } \\
\text { Technicon Corporation }\end{array}$ & $\begin{array}{l}\text { Luft Instruments, Ine. } \\
\text { Beckman instrumenzs, ine. }\end{array}$ & $\begin{array}{l}\text { Precision scienisic Comsany } \\
\text { Central Scienzitic Cenomeny }\end{array}$ \\
\hline \multicolumn{3}{|c|}{ Microwave } \\
\hline $\begin{array}{l}\text { Acurex Corporation } \\
\text { kank Presision Industries, Inc. }\end{array}$ & $\begin{array}{l}\text { Anacon, Ine. } \\
\text { Caltron Industries, Ine. }\end{array}$ & Microwave Instruments Company \\
\hline \multicolumn{3}{|c|}{ Miscelianeous } \\
\hline $\begin{array}{l}\text { Mason-ivilan Diviston, Horthington } \\
\text { Corporation (pressure) } \\
\text { Retammatic Corc. (expandable cartridgo) }\end{array}$ & $\begin{array}{l}\text { Seicor Division Seismograon Science } \\
\text { Corp. (for jonizable solids) }\end{array}$ & $\begin{array}{l}\text { Taylor Instruments, Process } \\
\text { Consroi Div. Syoron Corp. } \\
\text { (radioisotopes) }\end{array}$ \\
\hline \multicolumn{3}{|c|}{ Dielectric Constant } \\
\hline $\begin{array}{l}\text { inerican Meter Consrols, Inc. } \\
\text { Brubaker Electronics } \\
\text { Burrows Eouipnent Co. } \\
\text { Fischer and Porter } \\
\text { Foxboro Congany }\end{array}$ & $\begin{array}{l}\text { Paul W. Gardner Compeny } \\
\text { Greiner Scientific Coro. } \\
\text { Hallikainen Instruments } \\
\text { Honeywell } \\
\text { Hygrotester. Inc. }\end{array}$ & $\begin{array}{l}\text { Yoisture Register Company } \\
\text { "otomco Inc. } \\
\text { heston Instiment } \\
\text { Lusxs Laboratories, Inc. } \\
\text { F. H. Peavey and Company }\end{array}$ \\
\hline \multicolumn{3}{|c|}{ Infra-red } \\
\hline $\begin{array}{l}\text { Anacon, inc. } \\
\text { 3lock issociates, Inc. } \\
\text { Carle Instruments, Inc. }\end{array}$ & $\begin{array}{l}\text { General Electrie Co., Insirument Dept. } \\
\text { Molsture Pegister Company } \\
\text { Nucleonic Date Sysiems, inc. } \\
\end{array}$ & $\begin{array}{l}\text { Taylor Instruments, Process } \\
\text { Control Jiv. Syoron Corg. } \\
\text { iestiac ofvision of gol, inc. }\end{array}$ \\
\hline \multicolumn{3}{|c|}{ Irzedanse and Pesistance (Conduction) } \\
\hline 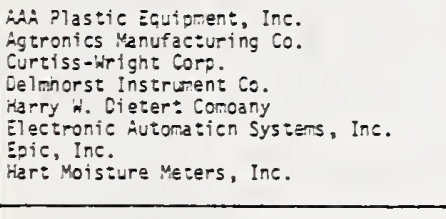 & $\begin{array}{l}\text { Henry Francis Farks Laboratory } \\
\text { Strandberg Engineering Labs., ine. } \\
\text { Security Engineering } \\
\text { Weston Instruments } \\
\text { Thwing-Albert Irstrument Co. } \\
\text { Chatnan International Coro. } \\
\text { gelco Electronics } \\
\text { Burrows Eouipment Comoany }\end{array}$ & 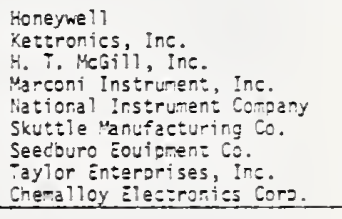 \\
\hline \multicolumn{3}{|c|}{ Chromatography } \\
\hline Bendix Corporation, Cincinnasi Div. & Carle Instruments, Inc. & Lockwout \& Melar-ie, inc. \\
\hline \multicolumn{3}{|c|}{ Oistillation } \\
\hline $\begin{array}{l}\text { Seedburo Equipnent Co. } \\
\text { California Laporazory Ee. Co. }\end{array}$ & Eurrows Equipment $\mathrm{Co}$. & Gerber Shee: Metal, Inc. \\
\hline \multicolumn{3}{|c|}{ Coulometric } \\
\hline \multicolumn{3}{|c|}{ Chemical Reaction } \\
\hline Heyl and Patterson, Inc. & \multicolumn{2}{|l|}{ Alpha-Lux Coroany } \\
\hline \multicolumn{3}{|c|}{ Power Loss } \\
\hline Sosnton Polytecrinic Company & & \\
\hline
\end{tabular}


APPENOIX E. SELECTEO COMPLIATIONS OF STANOARO REFERENCE OATA FOR HUMIOITY AND MOISTURE

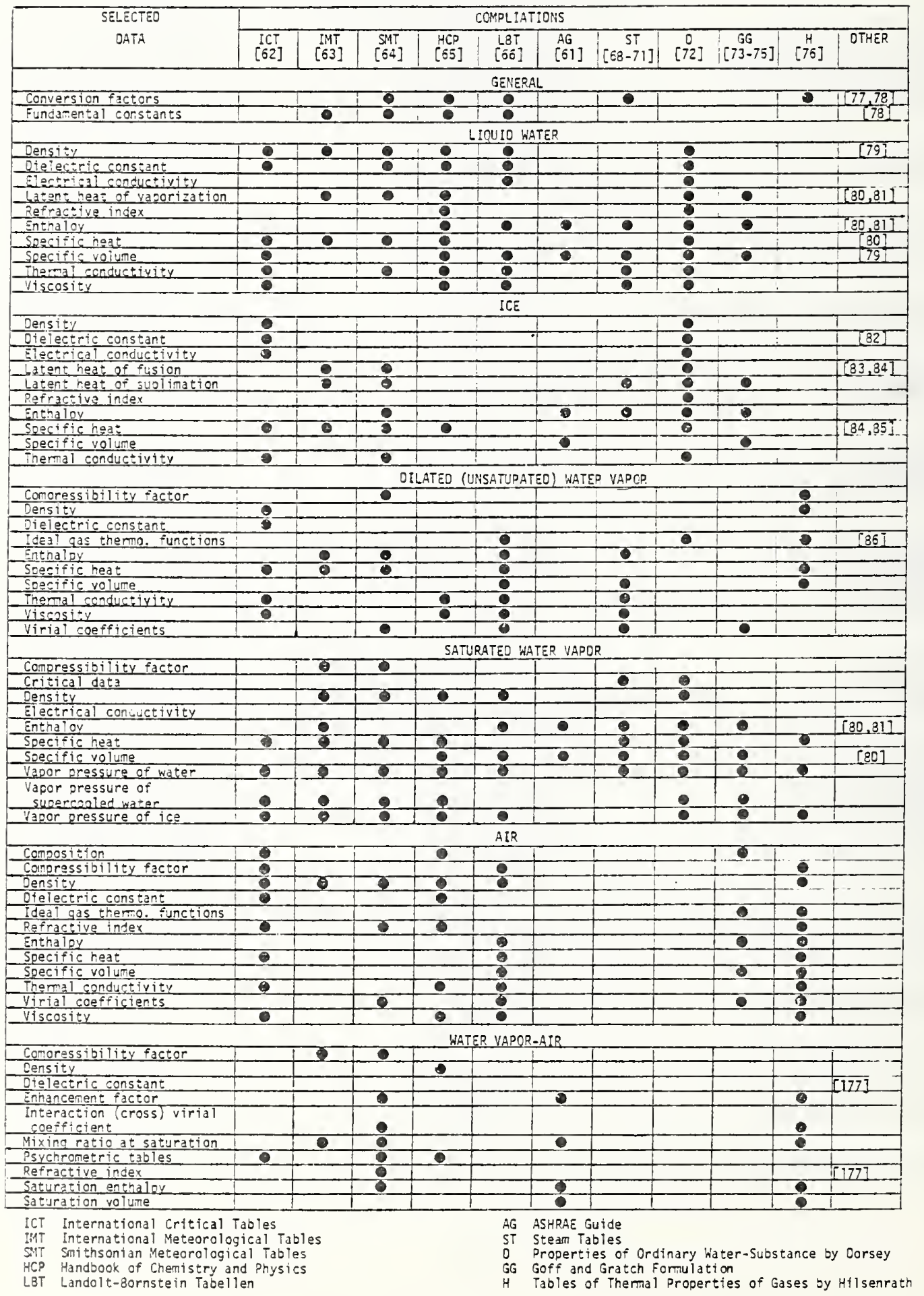


APFENDIX F. NES NTEREACES HITH USEPS OF HUMIOITY MEASUREMENTS SYSIEMS DVER THE FAST DECADE (ADVICE, CONSULTATIDN, DISSEMTKRTIDN DF INFDPMATIDN)

\begin{tabular}{|c|c|c|}
\hline 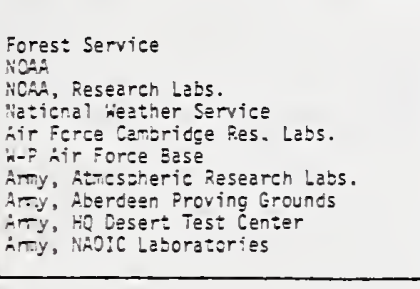 & 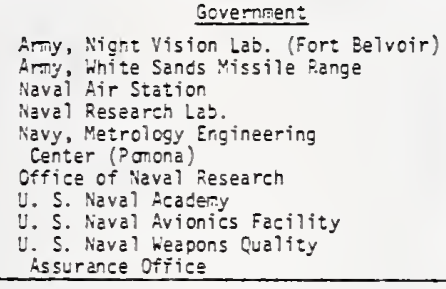 & $\begin{array}{l}\text { Marine Engineering lab. } \\
\text { AEC } \\
\text { Bureau of Mines } \\
\text { Geological Survey } \\
\text { Dept. of iransoortation } \\
\text { Federal Aviation Agency } \\
\text { EFA, SE Water Lao. } \\
\text { FedEral Trade Comission } \\
\text { MASA, Ames Research Center } \\
\text { NASA, Goddard } \\
\text { NASA, Langley }\end{array}$ \\
\hline 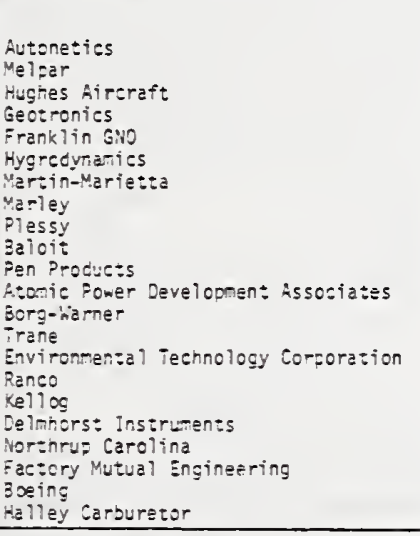 & 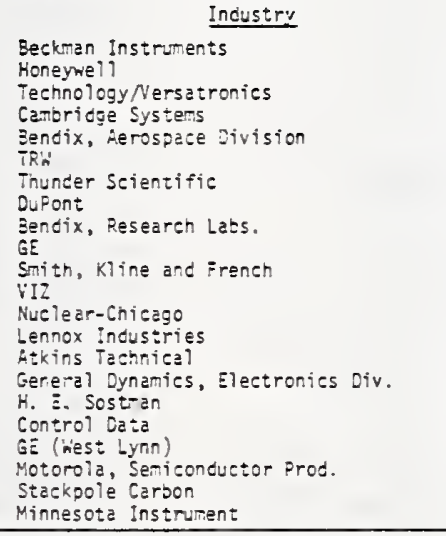 & $\begin{array}{l}\text { Vap-Air } \\
\text { IRC } \\
\text { Bendix, Environmental Divison } \\
\text { iranscontinental Gas Pipeline } \\
\text { Fairchild Hiller } \\
\text { Dow Chemical } \\
\text { Panametrics } \\
\text { Yellow Springs Instruments } \\
\text { Perta Pure Products } \\
\text { LTV Electrosysters } \\
\text { B. F. Goodrich Chemical } \\
\text { Hankison Corooration } \\
\text { Gulf Energy \& Environmental Systems } \\
\text { Haddan Hig. } \\
\text { Mee Industries } \\
\text { Union Carbide, Linde Division } \\
\text { Wing } \\
\text { Sperry Rand } \\
\text { Wagner-Insul } \\
\text { L. S. \& A. Electronics } \\
\text { Basic Inc. } \\
\text { Sylvania }\end{array}$ \\
\hline $\begin{array}{l}\text { Columbia University } \\
\text { Larigh University } \\
\text { Lousiana State } \\
\text { M! } \\
\text { liek Hexico State Universizy } \\
\text { hew York University } \\
\text { Dragon State University } \\
\text { Penr. S:ate University }\end{array}$ & $\begin{array}{l}\text { Colleces and Universities } \\
\text { San Diego State College } \\
\text { San Jose State College } \\
\text { Soutn Dakota School of Mines } \\
\text { \& Technolooy } \\
\text { Stanford University } \\
\text { University of Alaska } \\
\text { University of Califomia } \\
\text { University of Connecticut }\end{array}$ & $\begin{array}{l}\text { University of Hawaij } \\
\text { University of Maryland } \\
\text { University of Michigan } \\
\text { University of Missouri } \\
\text { University of Virginia } \\
\text { University of Washington } \\
\text { University oi Wisconsin } \\
\text { University of Wyoming } \\
\text { Utah State University }\end{array}$ \\
\hline $\begin{array}{l}\text { Acplied Pnysics Lat. } \\
\text { AVCC Everett Researen lab. } \\
\text { Bell ielepnone Labs. } \\
\text { 3ouser-yomer }\end{array}$ & $\begin{array}{l}\text { Institutes, Industrial Labs. Etc. } \\
\text { Esso Researen } \\
\text { Moore Susiness Foms-Res. Div. } \\
\text { HChR } \\
\text { Regional Science Res. Institute }\end{array}$ & $\begin{array}{l}\text { Undemiriter's Labs. } \\
\text { Westinghouse Research Lats. } \\
\text { Wylie Labs. }\end{array}$ \\
\hline 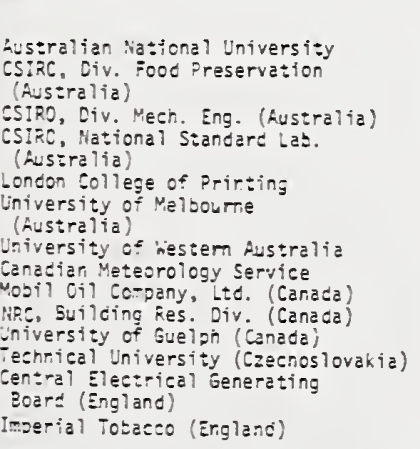 & 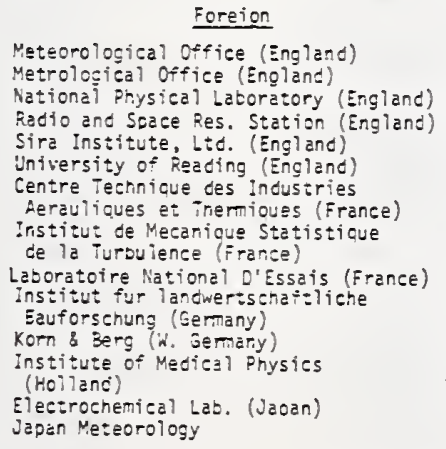 & $\begin{array}{l}\text { Hational Res. Lao. of Netrology } \\
\text { (Uapan) } \\
\text { Shizuoka University (Japan) } \\
\text { Labcratory of Low Jemo. (Netherlands) } \\
\text { CSIRo, Chem. Div. (New Zealand) } \\
\text { Det Norske Veritos (Norway) } \\
\text { Polish Camittee for Standization } \\
\text { and Measures } \\
\text { The Mational Institute for Materials } \\
\text { Testing (Sweden) } \\
\text { Mestle Prooucts Technical } \\
\text { Assistance Co. (Switzerland) } \\
\text { Sina Limited (Switzeriand) } \\
\text { Irstrument and Repair Calibration } \\
\text { Center (Thailand) } \\
\text { The Scientific and Technical } \\
\text { Research Council of Turkey }\end{array}$ \\
\hline
\end{tabular}




\section{REFERENCES}

[1] Huntoon, R. D., Concept of a national measurement system, Science 158, 67-71 (Oct. 1967).

[2] Huntoon, R. D., The measurement system of the United States, Proc. 1966 Standards Laboratory Conference, Misc. Pub. 291, National Bureau of Standards, 89-98 (Washington, U. S. Gov. Print. Off., 1967).

[3] Silverman, Shirleigh, The national measurement system, Mat. Res. Stds. 9, No. 10, 11-14 (1969).

[4] Wexler, Arnold and Hyland, R. W., The NBS standard hygrometer, NBS Ponograph 73, May 1, 1964 (U. S. Govt. Print. Off., Washington, D. C. 20402).

[5] Bongards, H., Feuchtigkeitsmessung, 53-64 (Munchen, OTdenbourg, 1926.

[6] Ibid, $64-76$.

[7] Yates, John T. Jr. and Madey, T. E., NBS, Informal communication.

[8] Mitcheli, J., Jr., and Smith, D. M., Aquametry, p. 168-172 (Interscience, New York, T948).

[9] Thuman, W. C. and Robinson, E., A technique for the determination of water in air at temperatures below freezing, J. Meteor. 11, 214-219 (1954).

[10] Weaver, E. R. and Riley, R., ileasurement of water in gases by electrical conduction in a film of hygroscopic material and the use of pressure changes in calibration, J. Res. NBS 40, 169-214 (1948).

[11] Amdur, Elias Jr., and White, Robert W., Two-pressure relative humidity standards, Humidity and Moisture, Editor-in-cnief Arnold WexTer Vol. III, 445-454 (Reinhold Publishing Corp., New York, 1965).

[12] Wexter, Arnold and Daniels, R. D., Jr. , Pressure-humidity apparatus, J. Res. NBS 48, 269-274 (1952).

[13] Hasegawa, S., Hyland, R. W. and Rhodes, S. W., A comparison between the Mational Bureau of Standards two-pressure humidity generator and the National Bureau of Standards standard hygrometer, Humidity and Moisture, loc. cit. Vol. III, 455-459.

[14] Shaw, W. N., Report on hygrometric methods, Trans. Roy. Soc. London I79A, 73 (1888).

[15] Wiegerink, J., G., Equipment for conditioning materials at constant humidities and at elevated temperature. J. Res. NBS 24, 639 (1940).
[16] Burcham, J. N., A variable temperature and humidity oven, J. Sci. Instr. 30 , 335 (1953).

[17] Edney, E. B., Construction and calibration of an electrical hygrometer suitable for microclimatic measurements, Bul1. Entomol. Res. 44, 333 (1953).

[18] Greenspan, Lewis, Low frost-point humidity generator, $J$. Res. NBS 77A, 671-677 (1973).

[19] Wexier, Arnold, Recirculating apparatus for testing hygrometers, J. Res. NBS 45, 357-362 (1950).

[20] Ti11, C. E. and Handegord, G. O., New humidity standard, Trans. ASHRAE, $288(1960)$.

[21] Wentze1, J. D., An atmosphere producer for laboratory use, Humidity and Moisture, loc. cit., Vol. III, 46T-4ह5.

[22] Walker, A. C., Supplying atmospheres of known humidity, Bell Lab. Record VII, 169 (1933).

[23] Gluckauf, E., Investigation on absorption hygrometers at low temperatures, proc. Phys. Soc. London 59, 344 (1947).

[24] Wexler, Arnold, Divided flow, low-temperature humidity test apparatus, J. Res. NBS 40, 479-486 (1948).

[25] Smith,'P. R., A new apparatus for the study of moisture sorption by starches and other foodstuffs in humidified atmospheres. Humidity and Moisture, loc. cit, Vol. III, 487-494.

[26] O'Keefe, A. E. and Ortman, G. C., Ana 7. Chem. 38, 760 (1966).

[27] Kertzman, J., A new humidity generator, Trans. Inst. Soc. imer. 7, 373-376 (1968).

[28] McKelvey, J. M. and Hoelscher, H. E., Apparatus for the preparation of very dilute mixtures, Anal. Chem. 29, 123 (1957).

[29] Gamache, L. D., A water vapor generator for use in hygrometer calibration and related fields, Analysis Instrumentation $3,167-176$ (1965).

[30] Wexler, Arnold Dew-point hygrometry, Humidity and Moisture, loc. cit., Vol. T, Section II, T25-2:5.

[31] Sonntag, D., Hygrometrie, Chap. 6, p. 547-666, (Akademie-Verlag, Berl in, 1966-i968).

[32] Greenspan, Lewis, A pneumatic bridge hygrometer for use as a working humidity standard. Humidity and Moisture

loc. cit., Vol. III, 433-443.

[33] Wildhack, W. A., Perls, T. A., et al, Continuous-absorption hygrometry with a pneumatic bridge utilizing critical flow, Humidity and Moisture, loc. cit., Vol., $552-570$. 
[34] Wexler, Arnold, Psychrometry, Humidity and lloisture, loc. cít., Vol. I, Section I, 3-121.

[35] Sonntag, O., Hygrometrie., Chap. 4 , 119-410. (Akademie-Verlag, Berlin, 1966-1968).

[36] Greenspan, Lewis and Wexler, Arnold, An adiabatic saturation psychrometer, J. Res. NBS 72C, 33-47 (7968).

[37] Keidel, F. A., Determination of water by direct amperometric measurement, Ana 1. Chem. 31, 2043 (1959).

[38] Crawshaw, J. K. and Davidson, F. G., Electrolytic hygrometer for the measurement of moisture in gases down to a few parts per million, J. Sci. Instr. 36,121 (1959).

[39] Cole, L. G., Czuha, M., et al., Continuous couiometric determination of parts per million moisture in organic liquids, Ana 1. Chem. 31, 2048 (1959).

[40] Czuha, Michael, Jr., Adaptation of the electrolytic moisture detector to atmospheric humidity measurement, Humidity and Moisture , loc. cit., Voi. I, 522-528.

[41] Czuha, M., Gardiner, K. W., and Sawyer, 0. T., The electrochemical behavior and analytical applications of the Pt $-\mathrm{P}_{2} \mathrm{O}_{5}-\mathrm{H}_{2} \mathrm{O}$ system, $\mathrm{J}$. Electroanal. Chem. 4,51 (1962).

[42] Jones, R. H., Additional performance data on a new electrolytic hygrometer ce11, Humidity and Moisture, loc. cit., Voi. I, 507-511.

[43] Walker, J. A. J., and Campion, P. The use of electrolytic hyorometers for the determination of $\mathrm{H}_{2} \mathrm{O}$ and $\mathrm{H}_{2}$, Analyst 90, 199 (1965).

[44] Goldsmith, P. and Cox, L. C., An improved electrolytic hygrometer, J. Sci. Instr. 44, 29-36 (1967).

[45] Bourke, P. J., and Dawson, R. W., Investigation of the accuracy of the Goldsmith-Cox electrolytic hygrometer at the $10^{-6} \mathrm{~atm}$ level, J. Sci. Instr. 44, 87-39 (1967).

[46] Gray, P. S. and Gordon, I., A pressurized Goldsmith-Cox hygrometer for plant use at ultra-low humidities, $J$. Sci. Instr. 44, 84-86 (1967).

[47] Magee, J. B. and Crain, C. M., Recording microwave hygrometer, Rev. Sci. Instr. 29, 51 (1958).

[48] Sargent, J., Recording microwave hygrometer, Rev. Sci. Instr. 30, 348 (1959).

[49] Hasegawa, S. and Stokesberry, D., Nicrowave hygrometer, NBS Report 10334 , Sept. 1970.
[50] Wexler, Arnold and Hasegawa, Saburo, Relative humidity-temperature relationships of some saturated salt solutions in the temperature range $0^{\circ}$ to $50^{\circ} \mathrm{C}$, J. Res. NBS 53, 19-26 (1954).

[51] Grover, O. W., and Nicol, J. M., The vapor pressure of glycerin solutions at $20^{\circ}, \mathrm{J}$. Soc. Chem. Ind. 59, 175 (1940).

[52] Wilson, R. E., Humidity control by means of sulfuric acid solutions with a critical compilation of vapor pressure data, Ind. Eng. Chem. 13,326 (1927).

[53] Collins, E. M., The partial pressure of water in equilibrium with aqueous solutions of sulfuric acid, $J$. Phys. Chem. 37, 1191 (1933).

[54] Montgomery, C. D., Googin, J. M. and Phillips, L. R., Moisture monitor testing and calibration, Humidity and Moisture, 10c. cit., Vol. III, 467-472.

[55] Wexler, Arnold, Measurement of humidity in the free atmosphere near the surface of the earth, Meteor. Monographs 11, 262-28? (1970).

[56] Luck, Winfried, Feuchtigkeit, Chapter 9, (O1denbourgh, Munchen, 1964).

[57] Shaffer, J. and Finley, C. M., Design criteria of a new moisture monitor for solids, Proc. Inst. Soc. Amer. 15 (2) (1960).

[58] Czuha, M. and Gardener, K. W., Analysis of water in jet fuels, Inst. and Control Syst. 34, 2074 (1961).

[59] Leibee, J. B. Electrolytic determination of moisture in rubber and textiles, Rubber Age 94, 924 (1964).

[60] Finley, C. M. and Shaffer, John, The detection of parts per million moisture in refrigerants, Humidity and Moisture, loc. cit., Vol. I, 529-535.

[61] Mitcheil, Jr., John and Smith, Donald 11., Aquametry (Interscience Publishers, Inc. New York, 1948).

[62] Washburn, E. M., (Editor), International Critical Tables (McGraw-Hill Book (o., New York, 1928).

[63] Letestu, S. (Editor), International Meteorological Tables, Who-No.188. TP. 94 (World Meteorological Organization, Geneva, Switzerland, 1966).

[64] List, Robert (Editor), Smithsonian Meteorological Tables, Sixth Revised Edition, (Smithsonian Institution, Washington, D. C. 1951).

[65] Weast, Robert $C$., Handbook of Chemistry and Physics (The Chemical Rubber Co., Cleveland, Ohio). 
[66] Landolt-Borrstein, Tabellen, Zuhiwerte und functonen, 6. Auflage, I (Springe!erlag, Berlin, 1960).

[67] ASHRAE Guide and Data Book, (American Society of Heating, Refrigerating and Air Conditioning Engineers, 1972).

[68] Meyer, C. A., McClintock, R. B. Silvestri, G. J., and Spencer, Jr., R. C., ASME Steam Tables, (The American Society of Mechanical Engineers, Hew York, N. Y., 1967).

[69] Keenan, J. H., Keyes, F. G., Hi.11, P. G. and Moore, J. G., Steam Tables, (John Wiley and Sons, Inc., New York, N. Y., 1969).

[70] Bain, R. W., NEL Steam Tables (Her ilajesty's Stationary Office, Edinburgh, 1964).

[71] Schmidt, Ernst, VDI-Wasserdamptabeln, (Springer-Verlag, Berlin, 1968).

[72] Dorsey, i. E., Properties of Ordinary Water-Substance, (Reinhold Publisining Corp., llew York, iv. Y. 1940).

[73] Goff, John A. and Gratch, S., Low-pressure properties of water from -160 to 212 F, ASHVE Trans. 52, 95 (1946).

[74] Goff, John A. and Gratch, S., Thermodynamic properties of moist air, Heating, Piping and Air Conditioning (ASHVE Journal Section) 17,334-348 (1945).

[75] Goff, John A., Fiñal Report of the Working Subcommittee of the International Joint Committee on Psychrometric Data, ASME Trans. 71, 903-913 (1949).

[76] Hilsenrath, J. et at., Tables of Thermal Properties of Gases, Nationa 1 Bureau of Standards Circular 564 , (U. S. Govt. Print. Off., Washington, D. C., 1955).

[77] Mechtly, E. A., The International System of Units, Physical Constants and Conversion Factors, NASA Sp-7012 TNational Aeronautics and Space Administration, U. S. Govt. Print. Off., Washington, D. C., 1964).

[78] Cohen, E. Richard and Taylor, $B$. M., The 1973 least-squares adjustment of the fundamental constants, $J$. Phys. Chem. Ref. Data 2, 663-734 (1973).

[79] Kell, G. S., Precise representation of volume properties of water at one atmosphere, J. Chem. Eng. Data 12,66 (1967).

[80] Osborne, H. S., Stimson, H. F., and Ginnings, D. C., Measurements of heat capacity and heat of vaporization of water in the range $0^{\circ}$ to $100^{\circ} \mathrm{C}$, J. Res. NBS 23, 197-260 (1939).
[81] Osborne, N. S., Stimson, H. F., and Ginnings, D. C., Thermal properties of saturated water and steam, J. Res. NBS 23, 261-270 (1939).

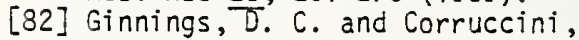
R. J., An improved ice calorimeter--the determination of its calibration factor and the density of ice at $0^{\circ} \mathrm{C}, \mathrm{J}$. Res. NBS 38, 583 (1947).

[83] Osborne, M. S., Heat of fusion of ice, A revision, J. Res. NBS 23,643 (1939).

[84] Dickinson, H. C. and Osborne, M. S., Specific heat and latent heat of fusion of ice, But1. Bur. Stds. 12,49 (1915).

[85] Giauque, W. F. and Stout, J. $\%$. The entropy and third law of thermodynamics, The heat capacity of ice from 15 to $273^{\circ} \mathrm{K}$, J. Amer. Chem. Soc. 58 , 1744 (1936).

[86] Friedman, A. S. and Haar, L., High-speed machine computation of ideal gas thermodynamic functions. I. Isotopic water molecules, J. Chem. Phys. 22, 2051 (1934).

[87] Franks, F., Water, A Comprehensive Treatise, Vol. I (Plenum Press, New York, 1972).

[88] Glen, John W. , The Physics of Ice, Cold Regions Science and Engineering Monograph II-C2a (Corps. Of Engineers, U. S. Army, Cold Regions Research and Engineering Laboratory, Hanover).

[89] Rieht, N. , Butiemer, B. and Engelhardt, H. , Physics of Ice (Plenum Press, New York 1969).

[90] Shatenshtein, A. I., Yakaleva, E. A., Zvyagintseva, E. N., Varshavskii, Ya. M., Israilevich, E. J., and Dykhno, N. M., Isoptopic Water Analys is, U. S. Atomic Energy Commission translation AEC-tr-4136, 2nd Edition (1960).

[91] American Chemical Society Specifications, Reagent Chemicals, 4th Edition (Am. Chem. Soc., Washington, D. C., 1968).

[92] Physical Society of London, Discussion on hygrometry (South Kensington, Nov. $25,1921)$, Proc. Phys. Soc. Lond. 34 , p. $i-x \in v(1921 / 1922)$.

[93] Wexier, Arnold (Editor-in-chief), Humidity and Moisture, Volumes 1-4, Reinhold PubTishing Corp., New York, 1965).

[94] International Measurement Confederation, Proceedings of the IMEKO-Symposium on Moisture Measurement, 5-8 October 1971 , Esztergom, Hungary. 
[95] Gregory, H. Spencer and Rourke, E., Hyarometry (Crosby Lockwood \& Son, Ltd., London, 1957).

[96] Pande, A., Modern Hygrometry (Somaiya Publications Pvt. Ltd., Bombay, 1970).

[97] Bongards, H., Feuchtigkeitsmessung (O1denbourg, Munchen, 1926).

[98] Luck, Winfried, Feuchtigkeit (0idenbourg, Munchen, 1964).

[99] Sonntag, Dietrich, Hygrometrie (AkademieVerlag, Berlin, 1966-1968).

[100] Lapinski, M., Kostyrko, K., and Whodarski, W., Nowoczesne Metody Pomiaru I ReguTacji Wilgotnosci (Wydawnictwa Naukowo-lechniczne, Warszawa, 1968).

[101] Steru, Marius, Masurarea A Electrica Umiditatu Materialelor (Editura Tennica, Bucuresti, 1957).

[102] Berliner, M. A., Humidity Measurements (Energy, Moscow, T973). (In Russian).

[103] Ikeda, Nagayoshi, Humidity and Moisture Measurement, 1965 (in Japanese).

[104] National Conference of Standard Laboratories, A Directory of Standard Laboratories, National Bureau of Standards, 1967 Edition).

[105] U. S. Federai Supply Service, Directory of U.S. Government Inspection Services and lesting Laboratories, (U. S. Govt. Print. Off., Washington $D$. C., 1967).

[106] GR Instruction 916-6 Equipment Manua 1, Chapter XII, Cven methods for determining moisture content of grain and related agricuitural commodities (U.S. Dept. of Agriculture, Consumer and Marketing Division 1971).

[107] Perry, Chemical Engineer's Handbook, (5th McGraw-Hill, liew York, T9/3).

[108] Greenspan, Lewis, Heated air adiabatic saturation psychrometer, J. Res. NBS 75C 69-78 (1971).

[109] Wexler, Arnold et a1., A fast responding electric hygrometer, J. Res. NBS $55,71-78$ (1955).

[110] Jones, Frank E. and Wexier, Arnold, A barium fluoride film hygrometer element, J. Geophys. Res. 65, 2087-2095 (1960).

[111] Jones, Frank, Evaporated-film electric hygrometer el ements, J. Res. NBSS $66 \mathrm{C}, 209-216(1962)$.

[112] Weaver, E. R., and Ledig, P. G., Detector of water vapor in closed pipes, Tech. Papers Bur. Stds. 17, 637 (1922-24); Ind. Eng. Chem. 15, 931 (1923).

[113] Weaver, E. R., Electrical measurement of water vapor with a hygroscopic film, Anal. Chem. 23, 1073 (1951).
[114] Weaver, E. R., Hughes, E. E., and Diniak, A. W., Determination of water vapor from the change in electrical resistance of a hygroscopic film, J. Res. NBS 60, 489-508, (1958).

[115] Di amond, H., Himman, Jr., W. S. and Dunmore, F. W., A method for the investigation of upper-air phenomena and its application to radio meteorography, J. Res. IIBS 20, 369-392 (1938).

[116] Dunmore, F. W., An electric hygrometer and its appiication to radio meteorography, J. Res. NBS 20, 723-744 (1938).

[117] Dunmore, F. W., An improved electric hygrometer, J. Res. NBS 23, 701-714 (1939).

[118] Diamond, H. and Hinman, Jr., W. S., An automatic weather station, J. Res. NBS 25, 133-148 (1940).

[119] Di amond, H., Hinman, Jr., W. S., Dunmore, F. W. and Lapham, E. G., An improved radiosonde and its performance, J. Res. NBS 25, 327-368 (1940).

[120] Weaver, E. R., Colorimetric determination of acetylene and its applications to the determination of water, Buil. Bur. Stds. 13 (1916-17).

[121] Kennedy, R. J., A method of determining the dew points of fuel-air mixtures, Bul1. Bur. Stds. 20 (1924-26).

[122] Tryon, M., An improved apparatus for determining moisture in rubber by distillation with toluene, NBS J. Res. 45, 362-365 (1950).

[123] Weise, E. L., Burke, R. W. and Taylor, J. K., Gas chromatograohic determination of the moisture content of grain, Humidity and Moisture, loc. cit., Vol. 4, 3-6.

[124] Carson, F. T. and Worthington, V., Apparatus for determining water-vapor permeability of moisture barriers, NBS Circular 453, (Nov. 8, 1946).

[125] Ziegler, C. A., and Schwebel, A., Techniques for monitoring tritiated-water vapor in air, Nucleonics 15, No. 1, 64 (1957).

[126] Wolfe, W. C., Differential dieiectric apparatus for determining water added to soivents, Anal. Chem. 35, 1884-1887 (Nov. 1963).

[127] Jones, F. E., Performance of the barium fluoride film hygrometer element on radiosonde flights, J. Geophys. Res. 68, 2735-2751 (1963). 
[128] Jones, F. E., Study of the storage stability of the barium fluoride film electric hygrometer element, J. Res., IBS 71C, 199 (1967).

[129] Gause, R. and Tucker, Jr., J. Method for determining the moisture condition of hardened concrete. J. Res. NBS 25, 403-416 (1940).

[130] Carson, F. T., Control of relative humidity in a small enclosed space, Paper Trade J. 93, 71 (1931).

[131] Carson, F. T., and Worthington, F. V., Hygrometry in paper testing, Paper Trade Jour. 94, No. 2, 34-42 (1932).

[132] Hasegawa, S., Garfinkel, S. B., and Wexler, A., Simple humidity lag apparatus, Rev. Sci. Instr. 26, 1196 (1955).

[133] Roth, F. L. and Stiehler, R. D., Control of relative humidity and temperature in rubber laboratory of Mational Bureau of Standards, Humidity and Moisture, loc. cit., Vol. 2, 287-292.

[134] Wexier, Arnold, Calibration of humidity-measuring instruments at the National Burea'!

of Standards, Trans. Inst. Soc. Amer. 7, 356-362 (1968).

[135] Rosa, E. B. and Babcock, H. D., On the variation of resistances with atmospheric humidity. Bul1. NBS 4, (1907-8).

[136] Weber, C. G. and Snydēer, L. W. , Reactions of Iithographic papers to variations in humidity and temperature, J. Res. NBS 12, 53-66 (1934).

[137] Carson, F. T., Permeability of membranes to water vapor with special reference to packaging materials, NBS Miscellaneous Publication 127 (1937).

[138] Carson, F. T., Effect of humidity on physical properties of paper., NBS Circular 445 (Jan. 31,1944 ).

[139] McGowan, F. R. and Schoffstall, C. W., Tentative standard test methods and percentages of $0 i 1$ and moisture in hair and press cloths, Tech. Papers of the Bur. Stds. 17, $(1922-24)$

[140] Wiegerink, J. G., Moisture relations of textile fibers at elevated temperatures J.Res. NBS 24, 645-664 (1940).

[141] Schenke, E. M. , and Shearer, $H$. E., Strength and elongation of silk yarns as affected by humidity, NBS J. Res. 25, 783-790 (1940).

[142] Schenke, E. M. and Shearer, H. E., Moisture content of thrown silk affected by threads and twist, Southern Knitter (Jan. 1940).
[143] Wier, J. E., Pons, D. C. and Axilrod, B. M., Effects of humidity during fabrication of polyester Taminates, SPE J. 8, No. 9, 8 (1952).

[144] Scheiber, D. J. and Mead, D. J., Effect of absorbed water upon the dielectric properties of certain acrylic ester polymers, J. Chem. Phys. 37, No. 1, 81-84 (July 1962).

[145] Scott, A. H. and Harris, W. P., Long-time effects of humidity change on the dielectric properties of certain polymers, (Proc. 1962 Annual Rept. Conf. Electrical Insulation, Hershey, Pa., Oct. 15-17, 1962), Nat'1. Acad. Sci-Nat'1. Res. Council Pub1. 1080, 4]-44 (1963).

[146] Scott, A. H., and Kinard, Jr., J. R., Polymeric materials for dielectric reference specimens, J. Res. NBS 71C, 119-125 (1967).

[147] Kanagy, J. R., Effect of oxygen and moisture on the stability of leather at elevated temperatures, J. Res. NBS 25, 149-160 (1940).

[148] Kanagy, J. R., Adsorption of water vapor by untanned hide and various leathers at $100^{\circ} \mathrm{F}$, NBS $\mathrm{J}$. Res. $38,119-128$ (1947).

[149] Kanagy, J. R., Influence of temperature on the adsorption of water vapor by collagen and leather, J. Res. NBS 44, 31-46 (1950).

[150] Kanagy, J. R., Influence of temperature on the adsorption of water vapor by collagen and leather, J. Amer. Leather Chemists Assn., 45, 12 (1950).

[151] Kanagy, J. R., and Vickers, R. A., Factors affecting the water vapor permeability of leather, J. Amer. Leather Chemists Assoc. 45, 211 (1950).

[152] ATmer, H. E., Response of microchemical balances to changes in relative humidity, J. Res. NBS 64C, 281 (1960).

[153] Brooks, Donald B., Correcting engine tests for humidity, J. Res. NBS $3,795-806$ (1929).

[154] Wright, J. R. and Bowman, P. B., The effect of temperature and humidity on the oxidation of air-blown asphalts, Mater. Res. Std. 2, No. 12, 988-995 (Dec. 1962).

[155] Davis, J. C. and Achenbach, P. $R$., An investigation of psychrometric measurement technique in air conditioning calorimetry, Humidity and Moisture loc. cit., Vol. 2, 303-313. 
[156] Loftus, T. P., Weaver, J. T., and Petrie, 3., Efiect of humidity on ionization measurements using cavity and free-air chambers, Radiology 86, No. 1 , 7 io (uan. 1960).

[157] Sigier, P. A., Mertens, R. I., and Koerner, E. A., Dimensional chenges of floor coverings with changes in relative humidity and temperature, 13S Building Materials and Siructures Report 85 (July $15,19 \div 2)$.

[158] Weir, C. E., High-pressure apparatus for compressibility studies and its application to measurements on leathar and collagen, J. Res. IISS $45,458-475(1950)$.

[159] Weir, C. E., The intluence of temperature and moisture on the electrical properties of leather, J. Res. iiss $48,349-359$ (1952).

[160] Weir, C. E., EFfect of moisture on compressibility of naturel high polymers, i:ss J. Res. 49, 135-139 (1952).

[161] Hebert, R. L., and HoDone11, $A$. $\equiv$., Note on the Kubela method of measuring water absorption of leather, J. Aner. Leather Chemists Assoo. 57, No. S, 461-459 (Sept. 1962).

[162] Kanagy, J. R., Moisture permeation of leather and piastics used in shoes, J. Amer. Leather Chem. A.ssoc. Tech. Hote LXIi, ilo. 2, 115-122 (Feb. 1967).

[163] Pitts, J. W. and Moore, D. G., Apparatus for studying the efiects of atmospheric poliution and cyclic dew formation on the deterioration of materials, îater. Res.

Std. 6 , 110. 7, 328-333 (July 1956).

[164] Diniak, A. W., Hughes, E. E.., and Fujii, $M$., Determination of water content in Freon-12 circulating in a refrigeration system, Refrig. Eng. 62 , $110.2,56$ (1954).

[1̧引] $3 e a n, \frac{5}{3}$. R., and HoGavin, R. E., The use of the radio reiractometer to measure water vapor turjuience, Humidity and "loisture, loc. cit., Vol. 2, $567-568$.

[iab] Gates, D. Y. , Vetter, 3. and Thompson, $M . C$. , heasurement of moisture boundary layers and leaf transpiration with a microwave refractometer, ilature 197, 1070-1072 (Viar. 1953).

[167] Gates, D. M. , The measurement of water vapor boundary 1 ayers in biologicel systems with a radio refractometer, Humidity and Moisture, loc.0it., Vol. $2,33-38$.

[168] Goltz, S. M., Tanner, C. 3., Thurtell, G. W. and Jones, $=$. E., Evaporation measurenents by an edidy correlation metrod, hater Resources E, ilo. 2, 440-446 (1970).

[169] Hyiand, Richerd $W$. and Wex]er, Arnold, The enhancsment of water in carbon dioxide-iree air at 30,40 and $50^{\circ} \mathrm{C} .$, J. Res. MBS $77 \hat{A}, 115-131(1973)$.

[170] Hyland, Richerd W. and Wexler, Arnold, The second interzotion (cross) virial coeficicient For moist air. U. Res. :BS 77A, 133-747 (1973).

[171] Johnson, D. P., Guildner, L. A., and Jones, F. E., Vapor pressure of kater at its triple point (presented at the 8th International Conierence on the Properties of hater and Stean, Hyeres-Giens, France, September $23-27,1974$ ).

[172] Wexler, Arnold and Greenspan, Lewis, Vapor pressure ecuation for water in the range 0 to $100^{\circ} \mathrm{C}, J$. Res. NES $75 \hat{A}$, 213-230 (1971).

[173] Littie, J. H., and Hasegawa, S., A small continuous-ilow humidity cenerator, MBS Report 10866 (1972).

[174] Wexler, Arnold and Brombacher, H. G., Betrods of meesuring humidi=y and testing hycrometers, WBS Circular 512 , (U. S. Gevt. Frint. Ofi. , Washington, D. C., Sept. 28, 1951 , Price 20 cents).

[175] Wexler, Arnold, Electric hychometers, NES Circular 586, U. S. Govt. Print. Off., lashington, D. C., Sept. 3, 1957, Price 20 cents).

[176] Wexler, Arnold, Hunidity standards, TAPPI 44, 180A-191A, (1961).

[177] Smith, E. K. and Weintraub, s., The constants in the equation for atrospheric refractive index at radio reauencies, Proc. I.R.E., 41, 1035-1037 (1953). 
NBS-114A (REV. 7.73)

\begin{tabular}{|c|c|c|c|}
\hline $\begin{array}{l}\text { U.S. DEPT. OF COMM. } \\
\text { BIBLIOGRAPHIC DATA } \\
\text { SHEET }\end{array}$ & $\begin{array}{l}\text { 1. PUBLICATION OR REPORT NO. } \\
\text { NBSIR 75-933 }\end{array}$ & $\begin{array}{l}\text { 2. Gov't Accession } \\
\text { No. }\end{array}$ & 3. Recipient's Accession No. \\
\hline \multicolumn{3}{|c|}{ A Study of The National Humidity And Moisture Measurement } & $\begin{array}{l}\text { 5. Publication Date } \\
\text { August } 1975\end{array}$ \\
\hline \multicolumn{3}{|l|}{ System } & $\begin{array}{l}\text { 6. Performing Organizarion Code } \\
\text { Wgagg } 221.06\end{array}$ \\
\hline \multicolumn{3}{|l|}{$\begin{array}{l}\text { 7. AUTHOR(S) } \\
\text { Arnold Wexler }\end{array}$} & 8. Performing Urgan. Report No. \\
\hline \multirow{2}{*}{\multicolumn{3}{|c|}{$\begin{array}{l}\text { 9. PERFORMING ORGANIZATION NAME AND ADDRESS } \\
\qquad \begin{array}{l}\text { NATIONAL BUREAU OF STANDARDS } \\
\text { DEPARTHENT OF COMMERCE } \\
\text { WASHINGTON, D.C. } 20234\end{array}\end{array}$}} & 10. Project/Task/Work Unit No. \\
\hline & & & 11. Contract/Grant No. \\
\hline \multirow{2}{*}{\multicolumn{3}{|c|}{ 12. Sponsoring Organization Name and Complete Address (Street, City, State, ZIP) }} & $\begin{array}{l}\text { 13. Type of Report \& Period } \\
\text { Covered } \\
\text { Final }\end{array}$ \\
\hline & & & 14. Sponsoring Agency Code \\
\hline
\end{tabular}

\section{SUPPI_EMENTARY NOTES}

16. ABSTRACT (A 200-word or less factual summary of most significant information. If document includes a significant bibliography or literature survey, mention it here.)

This study analyzes and assesses the status of the National Measurement System for humidity and molsture. It focuses on the physical process of measuring and controlling water vapor and moisture. It describes the nature, extent and economic dimensions of the system. It indicates impacts and trends, identifies deficiencies and shortcomings and shows the role NBS plays in the system. The study presents an overview of the complex structure of interrelated scientific, technological, social and economic components that form the basis of this system.

17. KEY WORDS (six to twelve entries; alphabetical order; capitalize only the first letter of the first key word unless a proper name; separated by semicolons)

Humidity; humidity measurement system;measurement of humidity; measurement of moisture; moisture; molsture measurement system; water vapor.

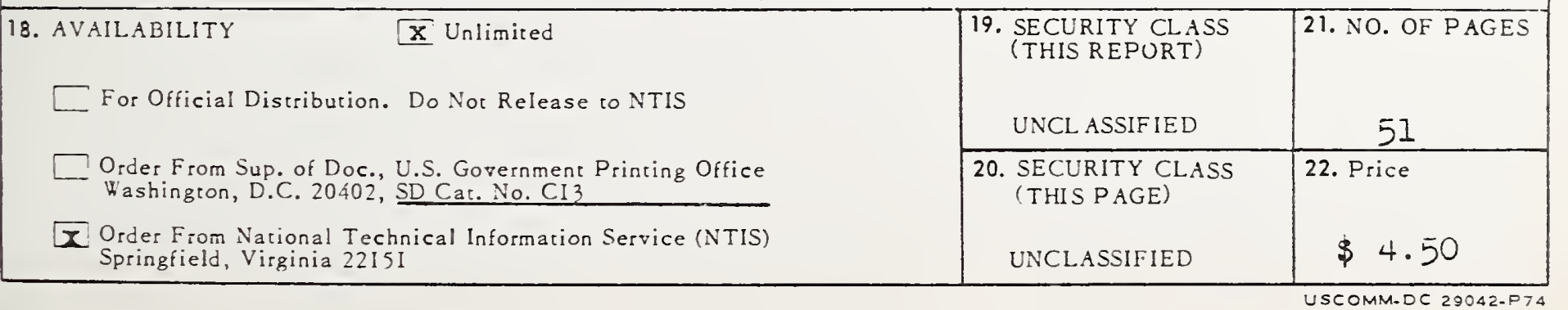


$=$ 

